\title{
International Union of Crystallography Thirteenth General Assembly and International Congress of Crystallography Hamburg, Federal Republic of Germany, 9-18 August 1984
}

\author{
Table of Contents
}

Introduction and Opening Ceremony ........ Thirteenth International Congress

\section{$\cdot \cdot \cdot$}

Minutes of the Thirteenth General Assembly

Introduction and list of delegates . . . . . . . .

First Session, Thursday 9 August 1984, 5.30 p.m.

(1) Introductory remarks by the President . . . .

(2) Procedural matters ...........

(3) Approval of the Agenda ...........

(4) Changes in Category of Adherence . . . . .

(5) Application for membership . . . . . . . .

(6) Approval of the Minutes of the Twelfth General Assembly ............

(7) Clarification of voting procedures . . . .

(8) Report of the Executive Committee . . . . . .

(9) Financial Report . . . . . . . . . . .

(10) Use of the donation from the Japanese crystallographic community ......... .

(11) Reports of the Commissions ..........

(12) Commission on Structure Reports . . . . . . .

Second Session, Friday 10 August 1984, 6.10 p.m.

(13) Commission on Journals . . . . . . . . . .

(14) Commission on International Tables . . . . . .

(15) Commission on Biological Macromolecular Crystallography (subsequently renamed Commission on Biological Macromolecules) . . . . . . .

(16) Commission on Crystal Growth and Characterization of Materials . . . . . . . . . .

(17) Commission on Crystallographic Apparatus . .

(18) Commission on Crystallographic Teaching . . .

(19) Determination of the number of elected members of each Commission ...............

(20) Proposal to establish a Commission on Small Organic Molecules (subsequently named Commission on Small Molecules) . . . . . . . .

(21) Reports of the Representatives on Scientific and Regional Associates ... . . . . . . . .

(22) Reports of the Representatives on bodies not belonging to the Union . . . . . . . .

(23) ICSU Abstracting Board . . . . . . . . .

(24) ICSU Committee on Science and Technology in Developing Countries (COSTED) . . . .

(25) ICSU Committee on the Teaching of Science . .

(26) Sub-committee on the Union Calendar . . . .

(27) Clarification of voting procedures (continued)

(28) Determination of the general policy and the timetable for the period to the Fourteenth General Assembly

Third Session, Tuesday 14 August 1984, 6.30 p.m.

(29) Number of elected members of the Commission on Small Molecules . . . . . . . . . . . .

(30) Determination of the general policy and the timetable for the period to the Fourteenth General Assembly (continued) . . . . . . . .
433

434

434

435

435

435

435

435

435

435

436

436

437

437

437

437

437

438

438

438

438

438

438

439

439

439

439

439

439

439

440

440

440
(31) Preliminary consideration of activities for the period 1987-1990 ... . . . . . . . .

(32) Budget estimates for the period to the Fourteenth General Assembly: determination of the unit contribution ............

(33) Confirmation of the date and place of the Fourteenth General Assembly ........ .

(34) Date and place of the Fifteenth General Assembly

(35) Confirmation of the appointments of the Editors of the publications of the Union ......

(36) Election of Chairmen and members of Commissions ............

(37) Election of Representatives on bodies not belonging to the Union and on Regional and Scientific Associates ...........

(38) Election of Officers of the Union ......

Closing Ceremony, Saturday 18 August 1984, 1.30 p.m.

Votes of thanks . . . . . . . . . . . .

Annex I: Appendices to the Agenda of the Thirteenth General Assembly . . . . . . . . .

(A) Report of the Executive Committee ... 444

(B) Financial Report . . . . . . . . . . . 445

(C) Use of the donation from the Japanese crystallographic community ..........

(D) Reports of the Commissions of the Union . . .

(E) Reports of the Representatives on Scientific and Regional Associates . . . . . . . . . .

(F) Reports of the Representatives on bodies not belonging to the Union ........

(G) Summary of the activities of the Sub-committee on the Union Calandar . . . . . . . . .

(H) Budget estimates for the period to the Fourteenth General Assembly: determination of the unit contribution ...........

Annex II: Statutes and By-Laws of the Union . . .

Annex III: Committees, Commissions, Regional and Scientific Associates and Representatives on bodies not belonging to the Union . .

Annex IV: Adhering Bodies and National Committees for Crystallography

\section{Introduction and Opening Ceremony}

By invitation of the Arbeitsgemeinschaft Kristallographie, the Thirteenth General Assembly and International Congress of Crystallography were held at the Congress Centrum, Hamburg, Federal Republic of Germany, 9-18 August 1984.

The meetings were attended by 1470 scientists from the Federal Republic of Germany and the following 48 countries: Algeria, Australia, Austria, Bangladesh, Belgium, Brazil, Bulgaria, Canada, People's Republic of China, Cuba, Czechoslovakia, Denmark, Arab Republic of Egypt, 
Finland, France, German Democratic Republic, Greece, Hong Kong, Hungary, India, Iran, Iraq, Ireland, Israel, Italy, Japan, Libya, Mexico, Netherlands, New Zealand, Norway, Pakistan, Poland, Portugal, Romania, South Africa, South Korea, Spain, Sweden, Switzerland, Taiwan, Thailand, Turkey, USSR, UK, USA, Venezuela, Yugoslavia.

The General Assembly and Congress were opened formally on the afternoon of 9 August. The Opening Ceremony commenced with speeches of welcome from Professor $\mathrm{H}$. SAALFEld, Chairman of the Organizing Committee, Professor F. K. F. Liebau, President of the Arbeitsgemeinschaft Kristallographie (AGKr), Professor U. K. E. BONSE, Chairman of the Programme Committee, Dr V. LANGE, Senator für Wirtschaft der Freien und Hansestadt Hamburg, and Dr P. Fischer-APPELT, President of the University of Hamburg. Dr J. KARLE, President of the International Union of Crystallography, replied on behalf of the Union. Professor N. Kato presided at the Congress Discourse given by Professor E. F. BERTAUT and entitled Commensurate-Incommensurate. The Opening Ceremony also contained two films by P. BRAMMER, entitled Mineralogical Symphony and Windjammer. A reception followed.

\section{Thirteenth International Congress}

\section{Scientific programme}

The scientific programme included the Congress Discourse by Professor Bertaut mentioned above and 16 Main Lectures. Two Main Lectures were held in parallel on each morning of the eight days of scientific sessions and were followed by five or six microsymposia, held in parallel. There were 40 such microsymposia. The afternoons were reserved for poster sessions and for ad hoc sessions. Nearly 1400 papers were presented, 1178 in poster sessions and the remainder in oral sessions. The detailed plan for the scientific programme had been compiled by an international Programme Committee at a preparatory meeting in August 1983. The abstracts submitted were printed, by direct reproduction of the typescript copy, in a book of Collected Abstracts and in a Supplement to Acta Crystallographica, Section A.

\section{Exhibitions}

There were exhibitions of commercial crystallographic equipment, non-commercial apparatus and items related to the artistic side of crystallography, developments of teaching aids, and books.

\section{Databases}

Demonstrations were held of the Inorganic Crystallographic Database (Fachinformationszentrum EPM), the Organic Crystallographic Database (Cambridge Crystallographic Data Centre), the Metals Data File (Canada Institute for Scientific and Technical Information) and the Protein Data Bank (Brookhaven National Laboratory). There was also a workshop on the use of the Powder Diffraction File (JCPDS).

\section{Social events}

A reception, a wine and cheese party and a Congress Excursion were organized for all participants, while a more extensive social programme was arranged for those accompanying the Congress participants.

\section{Scientific tours}

Five scientific tours were arranged during the Congress.

\section{Minutes of the Thirteenth General Assembly}

These minutes have been prepared by J. N. King, Executive Secretary, under the authority of K. V. J. Kurki-Suonio, General Secretary and Treasurer of the Union and Secretary of the General Assembly.

\section{Introduction and list of delegates}

Sessions of the General Assembly were held on the evenings of Thursday 9 August, Friday 10 August and Tuesday 14 August. The following list shows the names of official delegates appointed by the Adhering Bodies and of the alternates who substituted at one or more sessions. The names are listed by the countries to which the respective Adhering Bodies belong, and the number of votes of the country. The names of the Chairmen of the delegations are printed in bold type; those of alternates are marked by an asterisk. The names of officially appointed delegates who were not present at any session of the Assembly are not included.

Australia (3): H. C. Freeman, E. N. Maslen, A. F. Moodie. Belgium (2): G. S. D. King (present on 9 and 14 August), A. T. H. Lenstra* (present on 10 August).

Brazil (3): Y. P. Mascarenhas, A. R. D. Rodrigues (absent on 9 August), I. L. Torriani.

Canada (3): L. T. J. Delbaere, G. Ferguson, C. P. Huber. China, People's Republic of (4): J.-1. Huang, D.-c. Liang, Z.-z. Peng, Y.-q. Tang.

Czechoslovakia (1): J. Garaj (present on 10 and 14 August). Denmark (1): B. Lebech.

Egypt, Arab Republic of (1): M. S. Ahmed.

Finland (1): P. Suortti.

France (4): A. Authier, Y. P. Epelboin*, R. Fourme (absent on 9 August), M. Hospital.

German Democratic Republic (1): E. Höhne.

Germany, Federal Republic of (4): H. Burzlaff, W. Eysel*, H. Fuess, W. Prandl.

Hungary (1): L. Zsoldos.

India (2): R. Chidambaram, G. C. Trigunayat.

Israel (1): M. Kaftory.

Italy (3): C. Giacovazzo, G. Filippini, L. Mazzarella.

Japan (4): T. Ashida, S. Hoshino (absent on 14 August), Y. Iitaka, S. Nagakura (absent on 14 August).

Mexico (1): L. E. Rendón Díazmirón.

Netherlands (2): D. Feil, H. Schenk.

New Zealand (1): B. F. Anderson.

Norway (1): B. F. Pedersen.

Poland (1): D. Kucharczyk* (present only on 14 August), K. Łukaszewicz (absent on 14 August).

Portugal (1): L. Alte da Veiga.

South Africa (1): J. C. A. Boeyens.

Spain (3): M. Font-Altaba, S. Garcia Blanco, A. Lopez Castro.

Sweden (2): P. Kierkegaard, I. Olovsson.

Switzerland (2): H. B. Bürgi, D. Schwarzenbach.

$U K$ (5): D. M. Blow, D. W. J. Cruickshank, M. B. Hursthouse, B. J. Isherwood, E. J. W. Whittaker. 
USA (5): S. C. Abrahams, W. L. Duax, J. P. Glusker, W. A. Hendrickson, D. Sayre.

USSR (5): T. I. Malinovsky, Yu. I. Smolin, V. A. Timofeeva, B. K. Vainshtein, Yu. N. Venevtsev.

Yugoslavia (1): B. Kamenar.

The delegate from Mexico was admitted to the General Assembly after the application from the Consejo Nacional de Ciencia y Tecnologia for membership of the Union had been accepted at the first session of the Assembly on 9 August.

Present as members of the Executive Committee: J. Karle (President), S. Ramaseshan (Vice-President), K. V. J. KurkiSuonio (General Secretary and Treasurer), N. Kato (Immediate Past President), Th. Hahn, M. Nardelli, H. Neels, V. I. Simonov, M. M. Woolfson (Ordinary Members). Professor S. Amelinckx had resigned as an Ordinary Member just prior to the General Assembly. J. N. King was in attendance as Executive Secretary.

\section{First Session, Thursday 9 August 1984, 5.30 p.m.}

\section{(1) Introductory remarks by the President}

Dr KARLE welcomed the delegates and observers. He recalled with regret that the crystallographic community had been saddened by the loss of several of its distinguished friends recently, including Professor Sixten Abrahamsson from Sweden, the Chairman of the Union's Commission on Crystallographic Apparatus, Professor M. P. Shaskol'skaya from the USSR, a member of the Commission on Crystallographic Teaching, and Professor G. Kartha from the USA.

\section{(2) Procedural matters}

In order to verify the list of voting delegates, the President requested the General Secretary to read this list, and asked delegates to indicate their presence when their names were called. (This procedure was repeated at the beginning of each session of the General Assembly.)

Two delegates, Y. P. Mascarenhas (Brażil) and B. F. Anderson (New Zealand) were appointed to act as tellers when votes had to be counted during the Assembly.

\section{(3) Approval of the Agenda}

The Agenda and the Appendices to the Agenda had been distributed to Secretaries of National Committees on 31 May 1984. An additional item was added to the Agenda, concerning the application for membership from the Consejo Nacional de Ciencia y Tecnologia, Mexico.

\section{(4) Changes in Category of Adherence}

In December 1982 the Adhering Body for The Netherlands, the Stichting voor Fundamenteel Onderzoek der Materie met Röntgen- en Elektronenstralen (FOMRE) requested to reduce their Category of Adherence from Category III to Category II as from 1 January 1983. This request had been approved by the Executive Committee. The General Assembly passed a vote of appreciation of the immense contributions to crystallography from The Netherlands over the years and accepted the change in Category of Adherence.

In November 1982 the Adhering Body for India, the Indian National Science Academy (INSA), requested that their Category of Adherence be increased from Category I to Category II. This change had been approved by the Executive Committee. The General Assembly accepted the change. With this change of Category INSA was entitled to a second delegate and G. C. Trigunayat then joined the Assembly as their second delegate.

In April 1984 an application was received from the Adhering Body in the German Democratic Republic, the Vereinigung für Kristallographie in der GGW der DDR (VFK), to reduce their Category of Adherence from Category II to Category I. The General Assembly accepted the change in Category of Adherence.

\section{(5) Application for membership}

An application from the Consejo Nacional de Ciencia y Tecnologia (CONACYT), Mexico, had been received on 23 July 1984 and details had been distributed to delegates prior to the First Session of the General Assembly on 9 August. A provisional National Committee for Crystallography had been formed with the following membership: Dr L. E. Rendón Díazmirón (Chairman), Dr M. José Yacamán (Vice-Chairman), Dr M. Soriano García (Secretary), Dr O. Cano Corona, Fís M. de Teresa y Carral, Fís J. Tacher y Samarel, Ing J. Capallera Cabada. The Consejo Nacional de Ciencia y Tecnologia wished to adhere in Category I. The Executive Committee had considered the application and recommended to the General Assembly that the Consejo be accepted as an Adhering Body in Category I. This application was accepted unanimously and L. E. Rendón Díazmirón joined the Assembly as the delegate of the Consejo.

\section{(6) Approval of the Minutes of the Twelfth General Assembly}

One correction to these Minutes was noted, that L. T. J. Delbaere (not F. R. Brisse) had been a delegate for Canada. The Minutes were then approved and two copies were signed by the President and General Secretary, in accordance with By-Law 1/13. There were no matters arising from the Minutes.

\section{(7) Clarification of voting procedures}

This problem had been discussed in detail by the Executive Committee, based on comments received from several delegates. The President said that they were very concerned that everyone should understand the issues that came up for a vote. To try to ensure this, each motion would be shown on the overhead projector and explained. It would be appreciated if anyone had a question or did not understand the procedure or precisely what his or her vote would mean, they would say so immediately. Nowhere in the Statutes or By-Laws was there an exact statement of what should be done. Much of it really depended on the President's interpretation.

The Executive Committee hoped that they had come up with a system which was clear and easy to understand. The procedure would work as follows: A motion or proposal would be made with regard to some item. The proposal would need seconding. If there was no seconder then the proposal was not valid. After it had been seconded there would be discussion. If, in the course of that discussion, the motion was amended then the amendment would take precedence, i.e. the first motion to be voted on would be the amended motion and not the original one. Once a motion had been amended it would continue in much the same way as the original motion. If the amended motion 
was passed, then the subject was closed, and there would be no return to the original motion. If there was more than one amendment then the first one would be dealt with. If it was defeated then the second would be dealt with. A flow diagram had been prepared to try to simplify matters.

W. A. HENDRICKSON (USA) asked what the By-Laws said and the President replied that they were not clear. He explained that if delegates wished to raise more than one amendment they should do so immediately during the discussion. D. M. BLow (UK) proposed that this procedure should not be voted on at this session of the General Assembly but that it be postponed until the next session, to allow more time for discussion and other possible procedures. The President confirmed the interpretation given by D. W. J. CRUICKSHANK (UK) that the original motion was the major issue. If the amendment was one of detail only then all the arguments for and against the motion as well as the minor amendment should be brought up in the debate.

S. HoSHiNo (Japan) said that following the unhappy situation that arose at the last General Assembly in Ottawa regarding the level of the unit contribution, when there had been considerable discussion about the voting procedure and also the procedure for amendment of unit contributions, the Japanese National Committee had held considerable discussions and proposed an amendment to the Statutes and By-Laws to the Executive Committee in January 1984, but their proposal was not included on the Agenda papers. He asked the Executive Committee to explain why their proposal was not to be discussed under this item. The General Secretary explained that the proposal sent to him by the Japanese National Committee was for possible amendments to the Statutes and By-Laws, for discussion by the Executive Committee and possibly then for presentation to the General Assembly, although that had not been directly indicated in the letter. When the proposal was discussed by the Executive Committee, it was decided unanimously that the problems could not be solved in a satisfactory manner by changing the Statutes and By-Laws. Therefore it was decided not to propose any amendment to the General Assembly but rather to try to improve the procedures, so that no ambiguity whatsoever appeared in the voting procedures and everyone would be well aware of what they were voting for. The President explained that the Executive Committee felt that the problems involved were ones of communication and understanding what the votes meant. This is what the present discussions were trying to resolve.

The request to postpone any decision on voting procedures until the next session was agreed (see Minute 27).

\section{(8) Report of the Executive Committee}

The Report of the Executive committee on the activities of the Union since the Twelfth General Assembly had been submitted to the National Committees and the Commissions on 31 May 1984, in accordance with Statute 6.8, and this follows these Minutes as Annex I, Appendix A. The report was accepted without discussion.

\section{(9) Financial Report}

A Financial Report, covering the calendar years 1981, 1982 and 1983, had been prepared by the Treasurer and had been submitted to the National Committees and the
Commissions on 31 May 1984. The Report follows these Minutes as Annex I, Appendix B.

The Treasurer wished to show how the Union's finances had improved since the last General Assembly in Ottawa. The Finance Committee started its work immediately as it was obvious that rapid action was necessary. For the Union's finances to be in a healthy state its assets should be in the region of one year's operating costs, namely about 1.4 or 1.5 million Swiss Francs.

The finances are heavily dependent on the finances of the Union's journals. The most important action taken was a new agreement with the publishers of the journals, Munksgaard, on 1 January 1982. The prices of Acta Crystallographica and the Journal of Applied Crystallography were increased by about $40 \%$. One reason given at Ottawa for the Union's financial problems was rapid and unexpected changes in exchange rates. Therefore some guarantee against exchange-rate fluctuations was required, and the Finance Committee negotiated with the printers and persuaded them to quote fixed prices in Danish kroner. The next step was that the $10 \%$ commission to subscription agencies was terminated from the beginning of 1983. By the end of 1983 the Fund Account balances for the journals were very good. The effects of these actions had been much more successful than expected.

The Finance Committee considered that some further increase in the total assets of the Union up to the end of 1984 and possibly into 1985 could be expected, but it was not thought that such high increases as there had been between the Ottawa and Hamburg General Assemblies would be seen. The finances indicated that a new policy could be defined, which would make possible some good works. This had been discussed in detail in the Finance Committee and the Executive Committee, and the Treasurer had been given permission to read from the Minutes of the Finance Committee meeting a few points made with regard to possible future financial policy.

The President said that M. M. Woolfson, as Convenor of the Finance Committee, and the other members had all done an excellent job. A motion congratulating the President, the Treasurer and the Finance Committee for restoring the finances of the Union was carried unanimously.

In response to an enquiry from G. S. D. KING (Belgium), the President stated that no consideration had been given to the reintroduction of in-house computer typesetting, which had been abandoned three years ago, because it was very difficult to compete with commercial enterprises. He mentioned the computer at Chester and said that if we made use of our own computer facilities to compile the indexes for the journals, then the money saved would practically pay for the cost of the computer. L. E. RENDÓN Díazmirón (Mexico) felt that now the Finance Committee had done so well, it might be a good idea to try to make the journals more commercially attractive. The President said that they had a number of projects in mind and that they would have another look at the finances towards the end of the year, when they would have a better picture of whether there would be a comfortable excess. The National Committees and Commissions would be invited to submit proposals for good works, and the Executive Committee would also consider the needs of individual crystallographers.

The Financial Report was accepted unanimously and, in accordance with Statute $5 \cdot 10(i)$, the Treasurer and any 
other Officer or Chairman of a Commission were released from financial or other liability to the Union.

(10) Use of the donation from the Japanese crystallographic community

As reported at the previous General Assembly in Ottawa, the Japanese crystallographic community had collected 7000000 Yen (about US $\$ 35000$ ) as a donation towards the Union's publications. With the help of this generous donation a microcomputer with $384 \mathrm{~K}$ bytes of memory and $15 \mathrm{M}$ bytes of hard disc storage (with magnetic cartridge tape back-up) has been installed in the Union office at Chester. This computer enables the progress of all papers throughout the journal production process to be monitored, duplications identified, status reports listed and subject index, chemical name index, author index and formula indexes maintained. An engraved wall plaque commemorating the Japanese gift had been placed in the Chester office, with the following wording: "The first IUCr office computer, purchased with the help of a generous donation from the Japanese crystallographic community, was formally placed in service on 1 January 1984".

The General Assembly unanimously passed a motion recording its appreciation of this generous donation.

\section{(11) Reports of the Commissions}

The reports of the Commissions and their activities since the Twelfth General Assembly had been distributed to the National Committees and the Commissions in May 1984, in accordance with Statute 8.4. They are reprinted as Annex I, Appendix D to these Minutes; the Statutes and By-Laws are printed as Annex II to these Minutes. The reports were taken as read, but the Chairman of each Commission, or his alternate, was invited to say a few words about any further developments and to answer any questions. These verbal reports are summarized in Minutes 12-18, only the report on the Commission on Structure Reports being considered at the present session, the remainder being considered at the session on Friday 10 August (Minutes 13-18).

The Chairmen of the Commissions on Charge, Spin and Momentum Densities, Crystallographic Computing, Crystallographic Data, Crystallographic Nomenclature, Crystallographic Studies at Controlled Pressures and Temperatures, Electron Diffraction and Neutron Diffraction had nothing to add to their written reports and were not asked any questions by the delegates.

\section{(12) Commission on Structure Reports}

The Chairman of the Commission and Editor of Structure Reports, G. FERGUSON, reported that the editorial work on several new volumes was progressing satisfactorily. In response to questions, he confirmed that the Commission was in contact with the crystallographic databases and worked in cooperation with them.

The President adjourned the session at $7.50 \mathrm{p} . \mathrm{m}$.

Second Session, Friday 10 August 1984, 6.10 p.m.

\section{(13) Commission on Journals}

The Chairman of the Commission and Editor of Acta Crystallographica, S. C. ABRAHAMS, reported that the Commission had met for $2 \frac{1}{2}$ days earlier that week. It strongly reiterated that high-quality papers from all areas of crystallography were always welcome. Dr ABRaHams drew attention to the new Co-editors appointed in the last triennium, including C. E. Bugg and J. Drenth, both of whom represented the field of macromolecular crystallography. The Commission had decided to introduce a new set of articles in Acta, to be called Lead Articles, somewhat along the lines of the Lead Articles in J. Appl. Cryst. The Commission was somewhat concerned at the standards of some articles appearing in Acta Section C and the Commission hoped, by the January 1985 issues of the journal, to extract from Notes for Authors and give in tabular form some of the highlights which the Editors wished to bring to the attention of authors. A new short-format section would be introduced in Section C. Regarding the financial state of affairs of Acta, Dr ABRAHAMS observed that if one considered the final balance in the Acta account at the end of each year for the period 1978-1983, expressed in Swiss Francs, then the current position was very healthy.

D. M. BLOW (UK) asked if there was any possibility in the future of subscribing separately to Acta Section B. Dr ABRAHAMS said this had been considered very carefully by both the Finance Committee and the Executive Committee, and their feelings were that because Section C would change in character in 1985 it would be unwise financially to unbundle them in 1985, but this might be done in 1986 .

\section{(14) Commission on International Tables}

The Chairman of the Commission, A. J. C. Wilson, stated that Volume A, which had been edited by Th. Hahn and had been published in late 1983, was now sold out and was being reprinted. Volume II would shortly be sold out and he believed that the Executive Committee would authorize a reprint. Work on preparing new volumes of International Tables had been going along slightly different lines this time. A great deal of help had been received from those Commissions who were interested in the contents of the Tables and he thought that, in the course of the coming week, many of these Commissions would be meeting with the Editors of the Tables. There would be an Open Meeting of the Commission and Professor WiLson invited those interested in the general progress of International Tables to attend. There would also be a semi-closed session with the Commission on Electron Diffraction and he hoped there would be similar meetings with the Commission on Crystallographic Apparatus and the Commission on Neutron Diffraction later in the week. If Chairmen of any other Commissions would like to talk over ideas with the Editors, he would try to arrange a time.

J. P. GLUSKER (USA) asked when Volume B would be published, as there was nothing available on reciprocal space at the moment. Professor WILSON replied that the date by which the Editor was intending to finish the typescript was 31 January 1985 , but he could not say if this would be maintained. It was stated in the formal report that the time schedule had slipped by a few months. Completing the editorial work on a volume depended on receiving submissions from authors on time. He hoped it would appear in 1986 and hoped that Volume $C$ would be available a year later. He would welcome a reprint of Volume I but this would have to be referred to the Finance Committee. Dr GLUSKER had already written to the Executive Committee about this. What she really wanted was permission to reprint Volume $I$ or at least that part of it dealing with 
reciprocal space. Professor Wilson could see no editorial reason for not doing so, but for reasons of finance he must refer her to the Finance Committee. Dr GLUSKER asked the delegates if any of them also wanted this material reprinted but there was little support for the idea. Professor WILSON then asked Dr Abrahams if he could give a rough idea of the cost of 800 copies of a paper-bound reprint of the last third of Volume I. Dr ABRAHAMS guessed it might cost US $\$ 4000$. The President invited Dr GLUSKER to write to the Executive Committee again if she wished to pursue the idea suggested now, to reprint only that part of Volume I dealing with the reciprocal lattice.

Professor WILSON reported the possible production of an abbreviated version of Volume $A$ which would be useful for teaching purposes, and would contain enough space groups to cover $75 \%$ of organic structures and a rather smaller percentage of inorganic structures.

(15) Commission on Biological Macromolecular Crystallography (subsequently renamed Commission on Biological Macromolecules)

The General Secretary reported that there had been a proposal to change the name of the Commission to Commission on Biological Macromolecules. J. GARAJ (Czechoslovakia) cautioned that the proposed new name might be the same as an already-existing Commission of IUPAC. However, the proposal to change the name of the Commission was approved.

\section{(16) Commission on Crystal Growth and Characterization} of Materials

The Chairman of the Commission, E. KALdIS, observed that it was not normal for the Commission to organize or assist in so many schools in a triennium. The reason for this possibility was the very positive interest in materials science in developing countries.

\section{(17) Commission on Crystallographic Apparatus}

D. C. Creagh, acting Chairman of the Commission, reported that the Commission mourned the death of its Chairman, Sixten Abrahamsson, but was very grateful for the work done by P. Kierkegaard in taking over the organization of the Open Commission Meeting.

\section{(18) Commission on Crystallographic Teaching}

The Chairman of the Commission, P. KRISHNA, mentioned that, in addition to the Open Commission Meeting and the exhibition of books and teaching aids, films on crystallography would be screened during the Congress. Nine more teaching pamphlets had been published bringing the total to 19 .

\section{(19) Determination of the number of elected members of each Commission}

In accordance with Statute $5 \cdot 10(d)$, the Assembly had to determine the number of persons to be elected on the Commissions until the Fourteenth General Assembly; these numbers did not include Chairmen or ex officio members. Proposals had been received to increase the membership of the Commission on Crystal Growth and Characterization of Materials from 7 to 8 members, and that of the Commission on Electron Diffraction from 9 to 10 members. In both cases the motivation for such an increase was a broadening of the field. What had originally been set up as a
Commission on Crystal Growth was now also concerned with characterization of materials. Similarly, the range of activities under electron diffraction had increased. The Executive Committee recommended acceptance of these two proposals, and approval of the numbers of elected members of the other Commissions as set out in the General Assembly papers. This recommendation was approved.

The numbers of elected members approved by the General Assembly (Chairmen not included) are set out below:

1. Commission on Journals

2. Commission on Structure Reports

3. Commission on International Tables

4. Commission on Biological Macromolecules

5. Commision on Charge, Spin and Momentum Densities

6. Commission on Crystal Growth and Characterization of Materials

7. Commission on Crystallographic Apparatus

8. Commission on Crystallographic Computing

9. Commission on Crystallographic Data

10. Commission on Crystallographic Nomenclature

11. Commission on Crystallographic Studies at Controlled Pressures and Temperatures

12. Commission on Crystallographic Teaching

13. Commission on Electron Diffaction

14. Commission on Neutron Diffraction

(20) Proposal to establish a Commission on Small Organic Molecules (subsequently named Commission on Small Molecules)

The proposal to establish the Commission, together with the proposed terms of reference, was circulated with the Agenda papers. The General Secretary explained that the Assembly had now to decide whether to establish the Commission and, if so, determine the terms of reference and the number of elected members on the Commission. $\mathbf{R}$. ChIDAmbaram (India) said that this proposal had been discussed in his National Committee, who felt that the emphasis should be on small molecules of biological interest. The President felt that the Commission needed a shorter name. B. K. VAINSHTEIN (USSR) had no objection to the proposal but he would also like to have a Commission on Inorganic Crystals. D. M. BLow (UK) said the British National Committee was not convinced that there was a need for this new Commission. They thought that if a Commission was to be established it should be because there was felt to be a need for something specific to be done. They wanted to be convinced that there was a need for such a Commission, and they were also unhappy about increasing the number of Commissions without limit. They also wondered whether this interest was not one which should be considered in relation to IUPAC rather than IUCr, since the crystallography of such molecules was often now a rather routine matter. W. A. HENDRICKSON (USA) stated that there were many crystallographers in the USA working in this field who felt that the programmes of the IUCr did not cater for their needs. In the American Crystallographic Association (ACA) there were sub-groups of specific interest that had grown up over the last ten years and there was a very strong feeling that these sub-groups had improved the content of the ACA meetings. M. FONTAlTABA (Spain) suggested that, if this Commission was established, there should also be a Commission on 
Organometallic Crystals. He felt that the reasons put forward for the proposed Commission were not sufficient to justify its establishment.

H. C. FREEMAN (Australia) proposed an amendment to change the name to Commission on Small Molecules, and this was seconded by E. N. MASLEN (Australia). D. SAYRE (USA) proposed a second amendment to change the name to Commission on Biologically-active Small Molecules, and this was seconded by A. AUTHIER (France). After some discussion it was agreed to establish the Commission with the name of Commission on Small Molecules, with the following terms of reference:

(a) to advise the IUCr on organizing or sponsoring sessions on small-molecule structural analysis at Congresses and conferences.

(b) to promote and coordinate scientific exchange between countries in the field of small-molecule structural analysis.

(c) to cooperate with the Commissions of the Union on matters dealing with small-molecule structural analysis.

(d) to cooperate with other international bodies concerned in small-molecule structural analysis.

The size of the Commission approved by the Assembly was a Chairman and eight selected members. (However, see Minute 29 for a subsequent change in the number of elected members.)

(21) Reports of the Representatives on Scientific and Regional Associates

In accordance with Statute 8.5 , the reports of the representatives on Scientific and Regional Associates had been submitted to the National Committees and Commissions. The report on the International Organization for Crystal Growth (IOCG) had been circulated with the Agenda papers in May and the report on the European Crystallographic Committee (ECC) had been circulated in June. These reports are printed as Annex I, Appendix E to these Minutes. The reports were taken as read. The representative on the IOCG had nothing further to add. The representative on the ECC thanked the Executive Committee and $\mathbf{M}$. Nardelli for the help they had given.

(22) Reports of the Representatives on bodies not belonging to the Union

In accordance with Statute 8.5 the reports of the representatives on bodies not belonging to the Union had been submitted to the National Committees and Commissions in May; they are printed as Annex I, Appendix F to these Minutes. The reports were taken as read, but the representatives were invited to inform the Assembly of any further developments (see Minutes 23-25).

The representatives on the IUPAP Commission on the Structure and Dynamics of Condensed Matter, the Conference Committee of the European Physical Society, the ICSU Committee on Data for Science and Technology (CODATA), the ICSU Committee on Space Research (COSPAR), and the ICSU Scientific Committee on Problems of the Environment (SCOPE) had nothing further to add and were not asked any questions by the delegates.

\section{(23) ICSU Abstracting Board}

A. J. C. WILSON reported that the ICSU AB had held the predicted extraordinary General Assembly, had accepted new Statutes and By-Laws, and now had the name of
International Council for Scientific and Technical Information (ICSTI). The matter of its relations with ICSU was still not resolved. S. C. ABRAHAMS (USA) observed there were obvious undertones of unhappiness, and asked if things were now looking a little happier. Professor WILSON confirmed this. In response to a question from $D$. W. J. Cruickshank (UK), Professor Wilson stated that the Union belonged to ICSTI and, if it continued as a member, it would pay dues of US $\$ 500$ as from 1 January 1985, an increase of about US $\$ 100$ on its present subscription.

\section{(24) ICSU Committee on Science and Technology in Developing Countries (COSTED)}

A. AUthiER suggested that it might be superfluous to have a representative on COSTED in view of the lack of information from COSTED. H. SCHENK (Netherlands) asked if it was possible for the Union to do something about the situation. Professor Authier replied that the problem was really with ICSU and therefore it was agreed that the Union representative on ICSU should in future be the Union representative on COSTED.

\section{(25) ICSU Committee on the Teaching of Science}

J. P. GLUSKER (USA) asked if there was any discussion at these meetings about having more crystallography taught in chemistry courses. P. KRISHNA replied that such problems were not really the concern of the Committee.

\section{(26) Sub-committee on the Union Calendar}

A summary of activities of the Sub-committee was distributed with the General Assembly papers in June and is given as Annex I, Appendix $G$ to these Minutes. The Chairman of the Sub-committee, TH. HAHN, said that three more satellite meetings had been approved for the next Congress, in Australia.

\section{(27) Clarification of voting procedures (continued)}

The President reopened this item of business, which had been postponed earlier (see Minute 7), to discuss the changes proposed by the Japanese delegates. The General Secretary repeated his summary of the background to these proposals and the reasons why the Executive Committee had not included them in the General Assembly Agenda papers (see the penultimate paragraph of Minute 7). He observed that this decision had caused some dissatisfaction amongst the Japanese delegation and their National Committee, as they were of the opinion that it should have been included in the Agenda.

The Japanese delegates therefore now proposed the following procedure for the present General Assembly only:

"In the present General Assembly any proposed amendments to increase the unit contribution above that proposed by the Executive Committee should be made known to delegates at least forty-eight hours before the start of the General Assembly session at which the unit contribution will be considered."

The General Secretary explained that it was intended to consider the unit contribution at the third session, on 14 August.

After some discussion of the implications of such a procedure the General Assembly approved the proposal. 
(28) Determination of the general policy and the timetable for the period to the Fourteenth General Assembly

The Australian delegates proposed that the General Assembly requested the Executive Committee, when planning the budget for the General Fund, to give high priority to the provision of scholarships to enable talented young people to attend the Congresses of the Union. In making this proposal they informed the delegates that the International Union for Pure and Applied Biophysics offered scholarships of this type for its recent Congress. Scholarships equivalent to minimum air fares plus the Congress registration fee were awarded on the basis of (i) the abstract of a poster to be presented at the Congress and (ii) a supporting statement from the Head of the student's laboratory.

The President deferred the decision on this proposal until the third session of the General Assembly (see Minute 30).

The President then adjourned the session at 8.45 p.m.

\section{Third Session, Tuesday 14 August 1984, 6.30 p.m.}

(29) Number of elected members of the Commission on Small Molecules

The General Secretary reported that a proposal had been received from delegates to increase the number of elected members of this Commission. For this proposal to be considered by the General Assembly it had to be added to the Agenda, which required two-thirds of the votes represented at the General Assembly. In response to a request from the President, a motion was therefore proposed and approved to reopen the Agenda item on the Commission on Small Molecules (Minute 20) to reconsider the number of elected members of the Commission.

The General Assembly then discussed the proposal to increase the size of the Commission. The originally determined size was eight elected members. However, L. E. RENDÓN DÍAZMIRón (Mexico) understood there to be two nominations, in addition to the eight nominated by the Executive Committee. He therefore suggested the size should be increased to ten elected members. D. W. J. CRUICKSHANK (UK) agreed with other speakers that once the number of members of a Commission had been decided, it should not be changed except for grave reasons. This was a new Commission and therefore no-one knew how it would work, but there seemed to be keen support for it and so the Commission should be allowed to have the size of membership it wished. However, the Commission should understand that, should the motion be carried, this membership was fixed for the coming triennium only, and that in three years' time the Executive Committee might wish to recommend reverting to the originally proposed size.

It was agreed to increase the membership of the Commission to a Chairman plus ten elected members.

(30) Determination of the general policy and the timetable for the period to the Fourteenth General Assembly (continued)

The President invited discussion of this item which had been deferred from the previous session (Minute 28). There was no discussion and the proposal regarding scholarships was approved.
No other points were raised regarding the general policy or timetable to the Fourteenth General Assembly.

(31) Preliminary consideration of activities for the period 1987-1990

The General Secretary remarked that there was very little to be said on this subject, and he had nothing to add to what was in the Agenda papers. The President asked if there were any further comments. There were none.

(32) Budget estimates for the period to the Fourteenth General Assembly: determination of the unit contribution

The Treasurer referred to the budget distributed with the Agenda, and printed as Annex I, Appendix $H$ to these Minutes. He asked delegates to note that the amount for scientific meetings should read Sw Fr 306800 and not Sw Fr 296000 . The budget was based on the assumption that the unit subscription from Adhering Bodies remained unchanged at Sw Fr 890 . The budget was larger by Sw Fr 200000 than for the last triennium, partly because the unit contribution was increased as from 1982, giving an increase in income of Sw Fr 70000 . Also, in 1981 the Executive Committee had budgeted to receive Sw Fr 190000 as the yield from investments and banking accounts, but this in fact had been Sw Fr 350 000. The latter figure was included in the present budget. These were the most important changes on the income side. On the expenditure side all the increase had been in the item "Scientific Meetings".

The President said that he would eventually ask for approval of the budget but, as the unit contribution and the budget were tied, it would be inappropriate to approve the budget without approving the unit contribution first. He reminded delegates that the recommendation of the Executive Committee for the unit contribution was that it should remain the same, i.e. Sw Fr 890.

The General Assembly approved a unit contribution of Sw Fr 890 for the years 1985, 1986 and 1987. The General Assembly then approved the budget estimates without further discussion.

\section{(33) Confirmation of the date and place of the Fourteenth General Assembly}

The President said that everyone was well aware of the generous invitation from their Australian colleagues, and that the dates of the Fourteenth General Assembly and Congress would be 12-20 August 1987 at Perth, Western Australia.

The invitation, which had been preliminarily accepted in 1981, was formally accepted unanimously.

\section{(34) Date and place of the Fifteenth General Assembly}

The President said that in accordance with By-Law 1.3 the General Assembly might give preliminary consideration to the place of the next but one General Assembly, namely the Fifteenth General Assembly to be held in 1990. Four offers had been received, from the People's Republic of China, France, India and Spain. He hoped that the question could be resolved now as six years was not a long lead time these days. He suggested the following procedure. Representatives from the four countries would be asked to speak briefly, for about five minutes, highlighting the main points such as accommodation and facilities, etc. This would be followed by a ballot, using the same voting procedure as for the elections. All four countries would be 
on the first ballot form. There would be a secret vote and each delegate would vote for one of the four countries. If, at the end of the first ballot, one country had a majority of the votes, i.e. more than half, then the matter would be finished. If there was no majority then the one with the lowest number of votes would be eliminated and another ballot would be held, and so on until the question was resolved.

The President then invited speakers to address the General Assembly on behalf of the four invitations, in alphabetical order of country, suggesting that discussion should be deferred until all four speakers had had the chance to make their presentations.

Y.-Q. TANG (People's Republic of China) addressed the Assembly first. He said that every year since having been admitted in 1978 China had wanted to host the Congress. Crystallography had benefited greatly from the open-door policy. Accommodation and conference facilities had improved over the last few years. The China Association for Science and Technology (CAST) was closely related to Academia Sinica and adhered to ICSU. On behalf of these organizations he extended an invitation to hold the Fifteenth IUCr Congress in the People's Republic of China in 1990. CAST had told him that they could provide adequate facilities and personnel for the Congress and they would gladly organize sightseeing tours. University dormitories would be used for accommodation, and they were looking forward to welcoming everyone to Beijing in six years' time, if the General Assembly approved.

A. AUTHIER (France) then addressed the Assembly. He said that his colleagues had already started planning for the possibility of the Congress being held in France in 1990. They had obtained the support of the Académie des Sciences, which only supported the General Assembly of one Union per year, and this support had been reserved for the IUCr, if the General Assembly accepted the invitation. It was proposed to hold the meeting on a university campus, which would have many advantages including that of keeping the registration fees low. The university they had chosen was Bordeaux, the site of the first European Crystallographic Meeting in 1973, which many people would remember. The same team that organized the 1973 meeting would be involved in the Congress, headed by Dr M. Hospital. The support of the municipality of Bordeaux, the region and the university had been obtained. All the university facilities would be available, including the dormitories. There would be about 600 beds available cheaply (about US \$6-7 per night at today's prices). There were many hotels in the centre of Bordeaux, and bus services were good. There was also a Congress Centre with many hotels round it. The organizers might use the Congress Centre for special occasions, but in principle the Congress would be held at the University.

R. ChIDAMBaraM (India) then addressed the Assembly. He said that the crystallographers in India had been looking forward to the possibility of hosting a General Assembly for a long time. There was enthusiastic support from the Indian National Committee. They appreciated that it would be hard work, but felt it would benefit young crystallographers in India. They were thinking of holding the Congress and satellite meetings in New Delhi, where there was a Congress Centre and all facilities. Excellent accommodation was available, including hotels and university dormitories. They did not anticipate any problems with accommodation or transport and assured delegates of very warm hospitality, an excellent scientific meeting and the opportunity to visit many tourist attractions.

M. FonT-AlTABA (Spain) then addressed the Assembly. He said that the meeting would be in Barcelona, and that the Spanish crystallographers wanted to have the chance to be host to the big crystallographic family. Their reasons included the facts that they had been waiting since 1972 for this opportunity, when they first invited the Union to hold a Congress in Spain, and also that Spain was the only country involved in founding the Union which had not hosted an IUCr Congress. Barcelona had been chosen because it was on the coast in the middle of a tourist area and it would be easy to arrange visits to other parts of Spain. It was planned to hold the meeting at the Palacio des Congresos, which would be familiar to those people who attended the 1980 European Crystallographic Meeting. Hotels and student accommodation would be available in August. They had the support of the University of Barcelona, the city of Barcelona, the Catalan Government and the Government of Spain. However, should delegates decide to accept an invitation outside Europe for 1990, then the Spanish crystallographers would maintain the invitation to hold the Congress in Spain in 1993 or 1996.

The President thanked the four representatives for addressing the Assembly so enthusiastically and said that the matter was now open for discussion. In reply to a question from T. I. MALINOVSKY (USSR) he said that the first invitation received had been from India. The General Secretary presented a list of locations of previous Congresses with geographical distribution. G. S. D, KING (Belgium) said that geographical considerations were important. A Congress would not have been held in Europe for six years. It was a long way to travel to Australia and it would be a pity if participants had to travel so far again in 1990. On the other hand, the Australians had had to travel a long way for 13 Congresses. Another point to bear in mind was the desire to encourage crystallography in developing countries. One way to maximize the IUCr's service to crystallography world-wide would be to hold a Congress in Asia. In response to questions about the temperature in New Delhi and Beijing in August, the representatives assured delegates that it would be no hotter than at some previous Congresses, e.g. Stony Brook in 1969. Delegates were also assured that there would be no visa problems for a Congress in China.

The invitations were then voted on. Each ballot was very close. The final ballot resulted in the invitation from France being accepted.

\section{(35) Confirmation of the appointments of the Editors of the publications of the Union}

In accordance with Statute $7 \cdot 1$, the initial appointments and reappointments of the Editors of the publications of the Union were made by the Executive Committee and were subject to confirmation by the General Assembly. The Assembly unanimously confirmed the following appointment and reappointments for the period of three years:

Editor of Acta Crystallographica: S. C. Abrahams (USA) Editor of Journal of Applied Crystallography: M. Schlenker (France)

Editor of Structure Reports: G. Ferguson (Canada) 
Editor of International Tables and Editor of Volume C: Editor of Volume B: U. Shmueli (Israel)

A. J. C. Wilson (UK)

\section{(36) Election of Chairmen and members of Commissions}

The nominations made by the Executive Committee for the Chairmen and members of Commissions had been notified to the delegates and alternates.

For the Commission on Small Molecules, eight members had been originally nominated by the Executive Committee. Subsequently the Assembly increased the number of members to ten and two nominations were received from delegates. In the absence of other nominations being made by delegates, all persons nominated as Chairmen and members of Commissions were considered as elected. According to Statute $7 \cdot 3$, the Editors and Co-editors were automatically members of the Commissions set up for the publications concerned. The General Secretary explained that the Commission on Crystallographic Nomenclature consisted of the Editors of Acta Crystallographica, Journal of Applied Crystallography, Structure Reports and both Editors of International Tables with the Editor of Acta Crystallographica as chairman. He also explained that, for the Commission on Journals, in addition to the list of Co-editors given in the Agenda papers three more Co-editors had been appointed to replace Co-editors who had recently resigned.

Regarding the membership of the Commission on International Tables, the General Secretary informed delegates that in addition to A. J. C. Wilson (UK), who was Chairman of the Commission and Editor of Volume C, and U. Shmueli (Israel), who was Editor of Volume B (see Minute 35), at the request of the Chairman the Executive Committee had decided to nominate as ex officio members the Chairmen of the Commissions on Charge, Spin and Momentum Densities, Crystallographic Apparatus, Crystallographic Computing, Crystallographic Teaching, Electron Diffraction and Neutron Diffraction.

The full memberships of the Commissions including $e x$ officio members, together with the addresses of the Chairmen, are given in Annex III.

(37) Election of Representatives on bodies not belonging to the Union and on Regional and Scientific Associates

The nominations made by the Executive Committee for those representatives to be elected by the General Assembly had been notified to the delegates and alternates. No other nominations had been made.

The President drew attention to the fact that the Executive Committee had not nominated a Union representative on the ICSU Committee on Data for Science and Technology (CODATA). Normally the Chairman of the Commission on Crystallographic Data would be the respresentative. I. D. BRown (Canada), the retiring Chairman of the Commission, had requested discussion of this point in the General Assembly. He explained that he had been representative to CODATA for the last three years and had attended two of their General Assemblies during that period. CODATA was started some years ago, primarily to ensure that there were well-determined values of important data, mainly in the physical sciences. It now took a much greater interest in the publication of data, particularly using new technologies of computer databases. The IUCr had been one of the leaders in this technology. Our representative for many years, D. Watson, now the Treasurer of CODATA, had made some considerable contributions. CODATA was now trying to help the Unions concerned with geosciences and biological sciences to develop the same kinds of data systems as those available to crystallographers. CODATA had a new dynamic President who was very anxious both to gain more national members and to collaborate with various scientific Unions. When he had discussed CODATA with the IUCr Executive Committee, Professor Brown had agreed that, whilst the Union might not gain much by continuing membership of CODATA, he considered the Union had a lot to give CODATA. If we were to withdraw from CODATA, this could be seen as a vote of no confidence in it by a leading Union in the field of computer dissemination of data. Financial considerations were small, the only expenses being those of the delegate attending the General Assemblies. He recommended retaining membership, for at least the next three years. If the Executive Committee then wished to recommend withdrawal, then the Union representative and other interested parties should be given advance notice, to enable a case for continued membership to be made if appropriate. He had only heard of the decision of the Executive Committee not to recom. mend continuation of membership of CODATA about two days ago, and he had only managed to contact the President just before the present session of the Assembly. Neither he nor CODATA had been given time to consider the implications of withdrawal.

At the suggestion of the President it was agreed to continue representation on CODATA, the Union's representative being the new Chairman of the Commission on Crystallographic Data.

The President drew attention to the fact that the Executive Committee had also not nominated a Union representative on the ICSU Scientific Committee on Problems of the Environment (SCOPE). This decision had been made in agreement with the Union's present representative on SCOPE. The President explained that for many years the Executive Committee had hoped to see evidence of some rapport between the problems of the environment as handled by SCOPE and the possible contributions that crystallography could make to their activities. Because of the way SCOPE had been run over the years there had never been any opportunity whatsoever, and so it seemed there was neither any virtue for the Union to continue membership of SCOPE, nor any benefit that would accrue to SCOPE from IUCr membership. E. N. MASLEN (Australia) asked if SCOPE would be given reasons for the Union's nonrepresentation. The President replied that this had not been considered but that, if the Union was asked, a reply would be given but not otherwise.

The nominations made by the Executive Committee for these representatives were accepted by the General Assembly. S. C. ABRAHAMS (USA) suggested that, whilst representatives of the Union on bodies not belonging to the Union do a great service, there are cases where such representation is quite expensive in terms of travel expenses. He proposed that, whilst the Union continued to support the closest possible cooperation, if the representative had to travel large distances and incur great expense, it would be possible for another person nearer the location to represent the Union if appropriate. It was agreed that, in cases where high travel costs would be involved, a substitute closer to the meeting could be sent instead, as a representative of the elected representative. The decision would be 
made by consultation between the elected representative and the Treasurer.

The names and addresses of the representatives of the Union, including those appointed ex officio, are given in Annex III.

\section{(38) Election of Officers of the Union}

In accordance with By-Laws $2 \cdot 2$ and $7 \cdot 1$, the nominations made by the Executive Committee for Officers of the Union had been notified to delegates and alternates. These nominations had been included in the Agenda papers.

S. Amelinckx had resigned as a member of the Executive Committee. According to Statute 6.4 and By-Laws $2 \cdot 2$ and $7 \cdot 7$, the Executive Committee was required to present a nomination to fill the vacancy thereby created until the Fourteenth General Assembly and had nominated Y.-q. Tang.

As no counter-nominations had been made the Officers nominated were considered elected, as follows:

President:

Th. Hahn (Federal Republic of Germany)

Vice-President:

V. I. Simonov (USSR)

General Secretary and Treasurer:

K. V. J. Kurki-Suonio (Finland)

Ordinary Members (six years):

A. Authier (France)

A. Kálmán (Hungary)

E. N. Maslen (Australia)

Ordinary Members (three years):

R. Diamond (UK)

Y.-q. Tang (People's Republic of China)

There being no other business, the President declared the Thirteenth General Assembly concluded at 8.45 p.m. and thanked everyone for the good order and good spirit in which it had taken place.

\section{Closing Ceremony, Saturday 18 August 1984, 1.30 p.m.}

Professor H. Burzlaff took the chair.

\section{Votes of thanks}

The following votes of thanks were approved with Acclaim:

(a) S. Hoshino (Japan), speaking on behalf of the participants at the Congress, thanked the Organizing Committee and their colleagues for the excellent organization and arrangements which had contributed so much to a highly successful meeting. The meeting had helped to develop a deepening interest in crystallography as well as contributing to improved international understanding and friendship.

(b) S. RAMASESHAN, the retiring Vice-President, extended particular thanks to the international Programme Committee who had developed such an interesting and stimulating scientific programme.

(c) H. SAALFELD, Chairman of the Organizing Committee, responded on behalf of the German hosts. He expressed appreciation of the assistance given by the Deutsche Forschungsgemeinschaft, the Freien und Hansestadt Hamburg and the Union. He looked forward to the next Congress and wished the Australian organizers every success, with the advice to start at once.

(d) U. BONSE, Chairman of the Programme Committee, replied on behalf of his Committee. He thanked the Chairmen and Co-Chairmen of the microsymposia and main lectures, and gratefully acknowledged the support of many co-workers and his family.

(e) J. KARLE, the retiring President of the Union, introduced his successor Th. Hahn and the five new ordinary members of the Executive Committee. He recalled the loss of several colleagues in the last triennium, including $\mathrm{N}$. V. Belov, I. Nitta, W. H. Taylor and S. A. Bryant. He was delighted to see so much evidence that crystallography was flourishing, and suggested some fields which might develop rapidly in the near future. He, too, believed that the meetings and arrangements had been excellent. His only regret was that his presidential duties had given him little time to attend the scientific sessions. He and the Executive Committee were deeply grateful to the Programme and Organizing Committees and to their colleagues from the Federal Republic of Germany. He had been honoured to serve the Union as its President and thanked the Executive Committee and Finance Committee for their support. He wished the Union a successful future and was sure that it would be so under the leadership of Professor Hahn.

(f) TH. HAHN, the new President, thanked Dr Karle on behalf of all crystallographers for his leadership in the financial recovery of the Union, with the assistance of the Finance Committee. This Congress had shown many developments in our science, including an increasing awareness of the contribution of crystallography to applied research. He hoped that the Union would continue to serve the scientific community and contribute to what Dr Karle called 'good works'. He wished everyone goodbye and looked forward to meeting them again in Perth in 1987.

Professor Hahn then declared the Thirteenth General Assembly and Congress officially closed. 


\section{ANNEX I \\ Appendices to the Agenda of the Thirteenth General Assembly}

\section{Appendix A: Report of the Executive Committee}

\section{Meetings}

Since the Twelfth General Assembly and International Congress of Crystallography in Ottawa, many meetings have been held, or will be held prior to or immediately after the Thirteenth Congress, which have received Union sponsorship. These meetings are given below (* denotes financial support from the Union):* International School on Synthesis, Crystal Growth and Characterization of Materials for Energy Conversion and Storage, New Delhi, India, 12-23 October 1981; Meeting on Neutron Scattering and Diffraction Techniques for Macromolecular Structure Determination, Brookhaven, USA, 31 May-4 June 1982; *Workshop on the Crystallography of Molecular Biology, Erice, Italy, 7-19 June 1982; Sagamore VII Conference on Charge, Spin and Momentum Densities, Nikko Kanaya Hotel, Japan, 25-30 August 1982; Seventh European Crystallographic Meeting, Jerusalem, Israel, 29 August-3 September 1982; *International School on Materials Science and Solar Energy, Cairo and Alexandria, Egypt, 18 March1 April 1983; *International School on Teaching Crystallography for Materials Science, Brasilia, Brazil, 18-27 July 1983; Eighth European Crystallographic Meeting, Liège, Belgium, 8-12 August 1983; *International Summer School on Crystallographic Computing, Kyoto, Japan, 18-27 August 1983; *Fifth International Summer School on Crystal Growth and Materials Science, Davos, Switzerland, 3-10 September 1983; VII International Conference on Crystal Growth, Stuttgart, Federal Republic of Germany, 12-16 September 1983; Fifth European Meeting on Ferroelectricity, Torremolinos, Spain, 26 September-1 October 1983; International Course on Direct Methods of Solving Crystal Structures, Erice, Italy, 7-19 April 1984; *Conference on Crystal Growth and Characterization of Polytype Structures, Marseille, France, 3-6 July 1984; *International Summer School on Crystallographic Computing, Mulheim/Ruhr, Federal Republic of Germany, 30 July-8 August 1984; *Symposium on Neutron Scattering, West Berlin, Federal Republic of Germany, 6-8 August 1984; *Symposium on Small-Angle Scattering and Related Methods, Hamburg, Federal Republic of Germany, 20-23 August 1984; *Symposium on Metals and Intermetallic Compounds, Aachen, Federal Republic of Germany, 20-24 August 1984; *International Summer School on SymmetryRelated Crystal Structures: Group-Subgroup Relations, Marburg, Federal Republic of Germany, 20-24 August 1984.

The Executive Committee met in Ottawa in August 1981 before and during the XII General Assembly, in Frodsham, near Chester, England, in July 1982 and in Liège, Belgium, in August 1983. The Finance Committee met in Chester in the spring of 1982 and 1983 and prior to the Executive Committee meetings in those years.

At the Executive Committee meeting in 1982 the most important items of business were (1) approval of the audited accounts for 1981 ; (2) subscription rates and other matters concerning the Union's journals, including new arrangements with the publishers and the division of Acta Crystallographica into three sections; (3) other publications of the Union; (4) publication of macromolecular crystallography; (5) appointment of Editors for the new series of International Tables; (6) approval of membership of the Programme Committee for the XIII Congress; (7) sponsorship of meetings and possible financial support for satellite meetings at Congresses; (8) computer system for the Chester office; (9) problems experienced by Adhering Bodies in paying their subscriptions.

At the Executive Committee meeting in 1983 the most important items of business were (1) the arrangements for the XIII General Assembly and Congress with the Programme Committee; (2) consideration of subscription rates and other matters concerning the Union's journals; (3) other publications of the Union, in particular International Tables for Crystallography; (4) sponsorship of meetings; (5) approval of the audited accounts for 1982; (6) the General Fund estimates and the level of the unit contribution for 1985-1987; (7) suggestions from National Committees for membership of the Executive Committee and the Commissions.

More detailed reports of the activities of the Union are contained in the annual reports of the Executive Committee, which are published in Acta Crystallographica, Section A.

\section{Publications}

Acta Crystallographica was divided into three sections from 1 January 1983; Section A (Foundations of Crystallography), Section B (Structural Science) and Section C (Crystal Structure Communications). In 1981 the number of pages in Section A of Acta Crystallographica was 944 and in Section B was 2250, making a total of 3194 pages, excluding the joint index and the supplement containing 428 pages of abstracts communicated to the Twelfth Congress. In 1982 and 1983 the total number of pages were 4056 (Section A, 880; Section B, 3176) and 3434 (Section A, 950; Section B, 770 and Section C, 1714) respectively.

In 1981 the Journal of Applied Crystallography consisted of 502 pages, excluding indexes. In 1982 the number was 688 pages and in 1983672 pages. For Structure Reports, Volumes 36 (Ten-Year Index for 1961-1970), 46A, 47A (Ten-Year Index for 1971-1980), 48A, 44B and 45B were published in the triennium. Volumes 12,13 and 14 of Molecular Structures and Dimensions were also published.

The major work, Volume A in the new series International Tables for Crystallography, entitled Space-Group Symmetry, was published in 1983; Volume III of the old series was also re-printed. Other new publications include Fifty Years of Electron Diffraction, edited by P. Goodman, the first ten teaching pamphlets on crystallography, edited by C. A. Taylor with the support of the Commission on Crystallographic Teaching, and the sixth edition of the World Directory of Crystallographers. 


\section{Commissions of the Union}

Each Commission Chairman is required to provide a written triennial report to the General Assembly. These reports are given as Appendix D.

\section{Scientific and Regional Associates}

The reports of the representatives on these bodies are given as Appendix E.

\section{Union Representatives on Other Bodies}

The reports of the representatives of the Union on other bodies are given as Appendix $F$.

\section{International Council of Scientific Unions (ICSU)}

Professor Kato represented the Union at the 1981 and 1982 meetings of the ICSU General Committee and the 1982 meeting of the ICSU General Assembly, which was also attended by Dr King. Professor Magnéli represented the Union at the 1983 meeting of the General Committee. Dr King attended an informal meeting of Executive Secretaries of Unions and other ICSU bodies.

In 1982 the China Association for. Science and Technology was accepted as a National Member and the International Union of Microbiology and the International Union of Psychology were accepted as Scientific Union Members.

Also during the triennium the International Union of Food Science and Technology was accepted as a Scientific Associate and representative bodies from the Upper Volta and the Seychelles were accepted as National Associates.

The creation of an ICSU Press was authorized, in principle, and it has published the proceedings of a COGENE conference on genetic manipulation. No decision has been received from Unesco on the ICSU proposal for an International Institute for Crystallography, to be established in a developing country. The proposal was submitted to Unesco for inclusion in its Medium Plan for 1984-1989. Proposals to change the representation and voting power of the Unions in ICSU were again rejected by the General Assembly.

Two booklets have been published by the Committee on the Safeguard of the Pursuit of Science concerning the Florence Agreement on Importation of Educational, Scientific and Cultural Materials and Human Rights Laws, and a small booklet entitled ICSU:A Brief Review has been prepared by the ICSU Executive Secretary in both English and French. These are available free of charge from the ICSU Secretariat.

The Union continues to take part in the activities of several ICSU bodies. The triennial reports of the Union's representatives on these and other bodies are given as Appendices $\mathrm{E}$ and $\mathrm{F}$.

\section{Union Staff}

The present staff in Chester is: Dr J. N. King (Executive Secretary), Miss A. Whitley (Secretary), Dr D. W. Penfold (Technical Editor and Computer Manager), Dr J. E. Derry (Deputy Technical Editor), Mr M. H. Dacombe (Assistant Technical Editor), Miss S. E. Lowe and Miss A. J. Sharpe
(Editorial Assistants), Mrs J. I. Heywood and Mrs M. J. Robinson (Secretaries).

\section{Acknowledgements}

On behalf of the Union, the Executive Committee wishes to express its deep gratitude to the Arbeitsgemeinschaft für Kristallographie for the invitation to hold the Thirteenth General Assembly and International Congress of Crystallography in Hamburg. It particularly wishes to thank the Chairman of the Programme Committee, Professor U. Bonse, and the Chairman of the Organizing Committee, Professor H. Saalfeld.

The continuing support shown by Unesco in the form of its annual subvention received by the Union through ICSU, and the support of ICSU itself, is gratefully acknowledged.

Finally, the Executive Committee wishes to thank all crystallographers who have assisted in the work of the Union in so many ways. This cooperation between crystallographers of different nationalities constitutes a most valuable aspect of the Union's activities.

\section{Appendix B: Financial Report}

The accounts of the Union for the calendar years 1981 and 1982 have already been published [Acta Cryst. (1983), A39, 481-499 and (1984), A40, 68-85]. The accounts for 1983 have been audited and will be published in Acta Crystallographica, Section A, in due course [Acta Cryst. (1985). A41, 91-109].

The accounts for the three years 1981, 1982 and 1983 are summarized in Tables 1-12, in which all the amounts are expressed in Swiss Francs. Negative quantities are indicated by parentheses. The balance in each Fund Account at $\mathbf{3 1}$ December 1983 is given in Table 14. As a consequence of fluctuations in rates of exchange, a profit or a loss arose each year in terms of Swiss Francs. This gain or loss was divided amongst the Fund Accounts with credit balances, in direct proportion to the balances on these accounts at the end of the year in question. The fluctuation in exchange rates gave rise to a loss of Sw Fr 180942 in 1981, a gain of Sw Fr 25786 in 1982 and a loss of Sw Fr 27197 in 1983, leading to an overall loss of Sw Fr 182353 on fluctuations in exchange rates during the triennium. The exchange rates in operation at 1 January 1981 were Swiss Franc $1=$ Netherlands guilder $1 \cdot 36=$ Danish kroner $4 \cdot 03=$ pound sterling $0.289=\mathrm{US}$ dollar 0.568 . The exchange rates at 31 December 1983 were Swiss Franc $1=$ Netherlands guilder $1 \cdot 39=$ Danish kroner $4 \cdot 50=$ pound sterling $0 \cdot 314=$ US dollar 0.459 .

When the Acta Crystallographica and Journal of Applied Crystallography accounts (Tables 1 and 2) are examined, it should be noted that it was necessary to reduce the number of pages published in 1981 to limit the deficit due to the rapid change in the sterling/Danish kroner exchange rate. The subscription rates are increased substantially for 1982 and the backlog of papers was published during the year, thereby increasing the sizes of the journals. In 1983 Acta was divided into three sections, with a new Section $C$, Crystal Structure Communications, which was agreed to be a continuation of the Italian journal of the same title. However, the initial size of Section $C$ was smaller than estimated. The numbers of pages published in each section 


\author{
Income \\ Subscriptions \\ Sale of back numbers and single copies \\ Airfreight charges to subscribers \\ Royalties, copyright fees \\ Less Publisher's commission

\section{Expenditure} \\ Printing and binding \\ Distribution and postage \\ Airfreight costs \\ Indexes \\ Congress Supplement \\ Cancellation of computerized typesetting \\ facility \\ Editorial expenses \\ Transfer to Special Publications Fund \\ Administration expenses
}

Excess of income over expenditure

Gain on fluctuations in rates of exchange

Accumulated balance at the end of the year
Table 1. Acta Crystallographica

\begin{tabular}{|c|c|c|c|c|c|}
\hline \multicolumn{2}{|c|}{1981} & \multicolumn{2}{|c|}{1982} & \multicolumn{2}{|c|}{1983} \\
\hline 883,309 & & $1,239,589$ & & $1,511,324$ & \\
\hline 29,031 & & 48,810 & & 24,772 & \\
\hline 10,401 & & 20,049 & & 24,517 & \\
\hline 362 & & 253 & & 198 & \\
\hline 923,103 & & $1,308,701$ & & $1,560,811$ & \\
\hline 90,237 & 832,866 & 90,188 & $1,218,513$ & 107,527 & $1,453,284$ \\
\hline 529,976 & & 579,057 & & 433,183 & \\
\hline 50,868 & & 55,149 & & 67,061 & \\
\hline 22,871 & & 25,987 & & 29,394 & \\
\hline 18,599 & & 32,098 & & 30,453 & \\
\hline 22,506 & & - & & - & \\
\hline 93,446 & & 5,991 & & - & \\
\hline 294,128 & & 286,417 & & 294,015 & \\
\hline- & & - & & 8,194 & \\
\hline 32,100 & $1,064,494$ & 31,208 & $1,015,907$ & 31,511 & 893,811 \\
\hline & $r(231,628)$ & & Fr 202,606 & & w Fr 559,473 \\
\hline & $(25,082)$ & & 6,508 & & $(12,141)$ \\
\hline & Fr 108,515 & & Fr 317,629 & & w Fr 864,961 \\
\hline
\end{tabular}

Table 2. Journal of Applied Crystallography

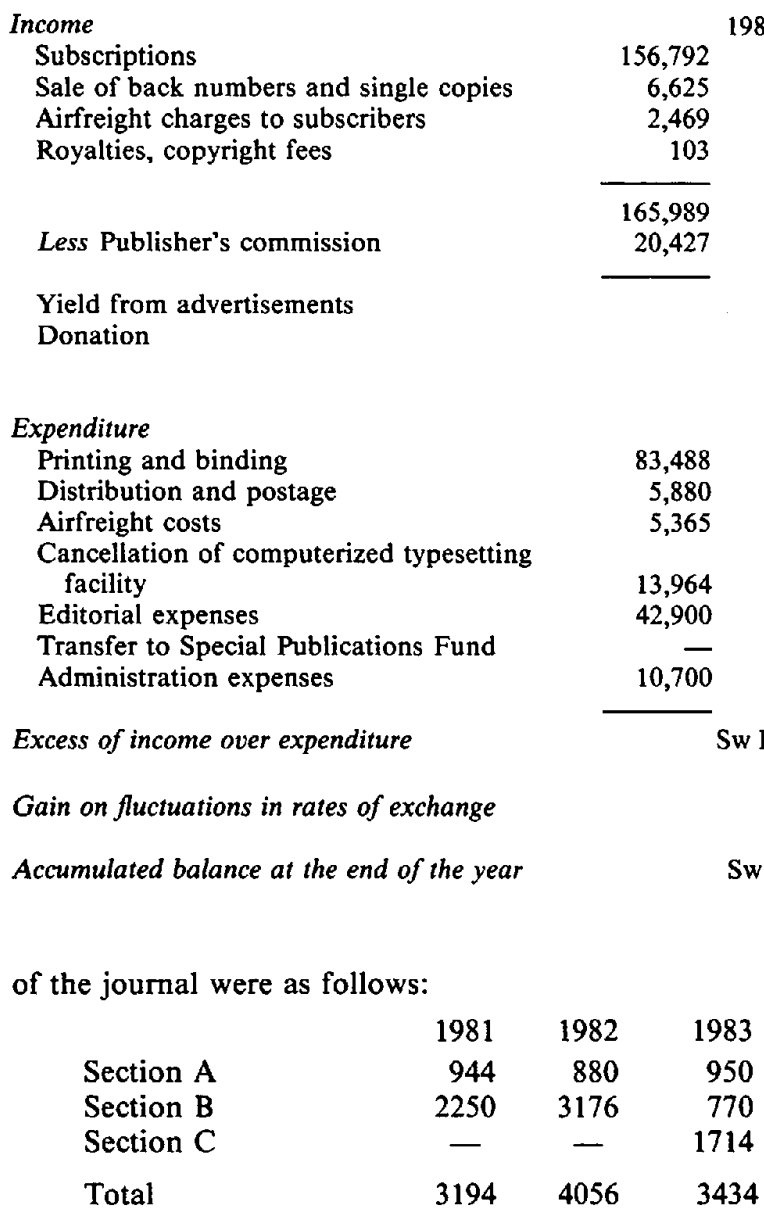
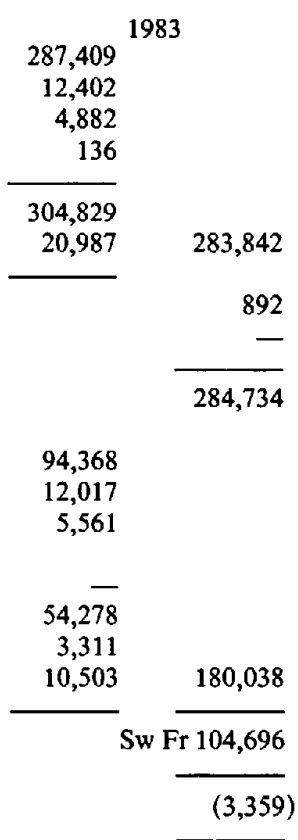

Sw Fr 239,292

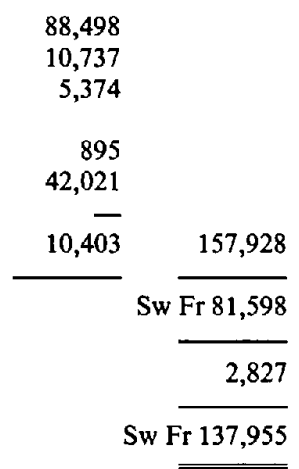

In addition, Section $\mathrm{A}$ included 428 pages of Congress Abstracts in 1981.

For Acta Crystallographica (Table 1) the full-rate subscription was Dkr 2720 in 1981, Dkr 4100 in 1982 (for Sections A and B combined) and Dkr 5125 in 1983 (for Sections A, B and C combined). The numbers of paid subscriptions to one or more Sections of the journal were 
Table 3. Structure Reports

\author{
Income \\ Sale of copies \\ Less Publisher's commission \\ Expenditure \\ Printing and binding new volumes \\ Typing of manuscripts \\ Editorial expenses
}

Excess of income over expenditure

Gain on fluctuations in rates of exchange

Accumulated balance at the end of the year
1981

\begin{tabular}{r}
129,000 \\
34,475 \\
\hline \\
11,062 \\
8,554 \\
71,763
\end{tabular}

Sw Fr 3,146

$(43,249)$

Sw Fr 187,113
1982

\begin{tabular}{r}
162,405 \\
43,049 \\
\hline \\
44,304 \\
7,916 \\
59,897
\end{tabular}

119,356

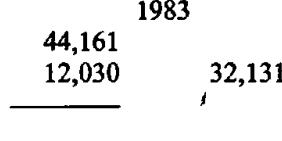

32,131

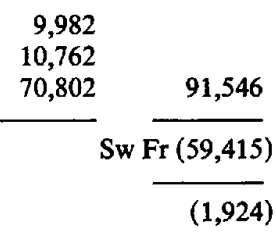

Sw Fr 137,079 as follows:

$\begin{array}{lrrr} & 1981 & 1982 & 1983 \\ \text { Sections A, B (and C) } & 1319 & 1295 & 1197 \\ \text { Section A only } & 258 & 254 & 271 \\ \text { Section B (and C) } & 145 & 140 & 142\end{array}$

Included in these numbers were the following numbers of personal subscriptions at reduced prices:

$\begin{array}{lrrr} & 1981 & 1982 & 1983 \\ \text { Sections A, B (and C) } & 126 & 132 & 145 \\ \text { Section A only } & 58 & 57 & 62 \\ \text { Section B (and C) } & 19 & 18 & 13\end{array}$

In spite of the restriction on the number of pages published and a $20 \%$ increase in the subscription rates in Danish kroner, the net subscription income in 1981 in Swiss Francs was less than for 1980 , because of the dramatic fall in the value of the kroner. In addition, a loss of Sw Fr 93446 was sustained from cancelling the computerized typesetter.

In 1982 a new agreement with Munksgaard, the publisher of Acta Crystallographica and the Journal of Applied Crystallography, led to large interim payments to the Union during the year, the payment of interest on the Union's money held by the publisher and a reduction of Munksgaard's commission on sales to $7 \%$. The journal accounts are now less susceptible to exchange-rate fluctuations because the publication expenses are incurred in Danish kroner and the subscriptions are received in the same currency. This arrangement, together with the large increase in subscription rates, led to a profit for that year.

The division of Acta into three sections in 1983 created large uncertainties in planning the budget. The subscription rates were determined to yield a surplus comparable to that of the previous year. However, the number of pages printed was substantially less than estimated and the fall in the number of subscriptions was also less than expected. A further economy was made in 1983 by terminating the $10 \%$ commission given to subscription agencies. The technical editorial expenses for 1983 include a charge of Sw Fr 8194 as a contribution towards the purchase of the office computer, which was made possible by the generous donation from the Japanese crystallographic community.

The Journal of Applied Crystallography accounts are given in Table 2. The full subscription rates were Dkr 640, Dkr 1030 and Dkr 1225 for 1981, 1982 and 1983, respectively. The number of paid subscriptions were 1126,1105 and 1072 including 96,98 and 115 personal subscriptions at reduced prices, and the numbers of published pages were 492,676 and 661 in 1981,1982 and 1983, respectively. The increases in the subscription rates for 1982 and 1983, as for Acta Crystallographica, led to excesses of income over expenditure for both these years. The termination of the commission to subscription agencies and the smaller than expected size of the journal in 1983 led to a higher surplus than estimated. The editorial expenses include a charge of Sw Fr 3311 to technical editing towards the cost of the computer.

The costs of the technical editing office are divided between Acta Crystallographica and Journal of Applied Crystallography accounts in percentages based on the number of text pages published during the year. For Journal of Applied Crystallography this was 13\% in 1981 and 1982 and $17 \%$ in 1983.

The Structure Reports accounts are shown in Table 3. Volume 45A was published in 1981, Volumes 44B, 46A and 47A in 1982 and Volume 36 (the Ten-Year Index 1961-1970) in 1983. Small profits were made in 1981 and 1982 but a substantial loss was incurred in 1983, because sales were very low, with no annual volumes being published, and there were still considerable editorial expences for new volumes to be published in the near future.

The International Tables for $X$-ray Crystallography accounts are shown in Table 4. In late 1981, the publisher of International Tables, Kynoch Press, ceased to trade and D. Reidel Publishing Company, who have handled other IUCr publications since 1980 , took over. It had been expected that Volume A on Space-Group Symmetry would be published in 1982 but there were delays in the final stages of production, and it was not available until late 1983. In addition to the cost of printing, about half the editorial expenses in 1983 related to Volume $A$ (the remainder being for preparatory work for Volumes $B$ and $C$ ). There have also been substantial editorial expenses over the many years of preparation of this volume. With the publication of Volume $A$ these expenses have been recovered and the accumulated balance was positive at the end of 1983, for the first time for many years.

Table 5 summarizes the accounts for Fifty Years of X-ray Diffraction. Table 6 shows the accounts for Symmetry Aspects of M. C. Escher's Periodic Drawings, for which royalties continue to be received from the commercial publisher of the Japanese edition published in 1980. 
Table 4. International Tables

Income

Sale of Volume A

Sale of Volumes II, III \& IV

Less Publisher's commission

Copyright fees

\section{Expenditure}

Printing Volume A

Reprinting Volume III

Editorial expenses

Excess of income over expenditure

Gain on fluctuations in rates of exchange

Accumulated balance at the end of the year

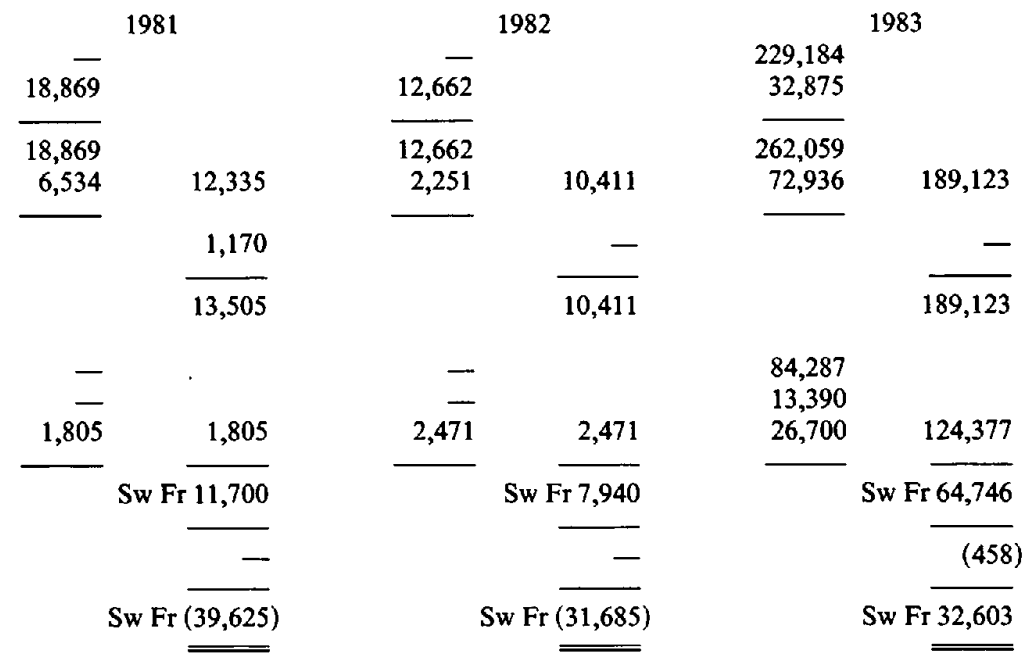

Table 5. Fifty Years of X-ray Diffraction

Income
Sale of copies
Less Publisher's commission

Excess of income over expenditure

Gain on fluctuations in rates of exchange

Accumulated balance at the end of the year

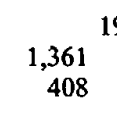

1981

408

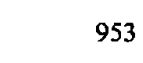

Sw Fr 953

$(1,045)$

Sw Fr $\overline{4,520}$

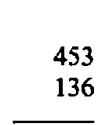

1982

136

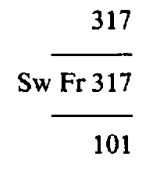

Sw Fr 4,938
1983

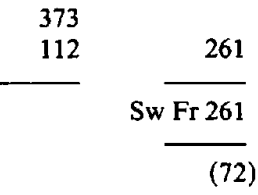

Sw Fr $\overline{5,127}$

Table 6. Symmetry Aspects of M. C. Escher's Periodic Drawings

Income
Sale of copies
Less Publisher's commission

Royalties

Excess of income over expenditure

Gain on fluctuations in rates of exchange

Accumulated balance at the end of the year

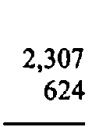

1981

\begin{tabular}{l}
1,683 \\
2,214 \\
\hline 3,897
\end{tabular}

Sw Fr 3,897

$(4,500)$

Sw Fr $\overline{19,469}$
1982

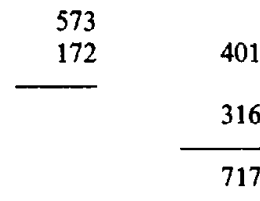

$\begin{array}{r}653 \\ 196 \\ \hline\end{array}$

1983

457

$\frac{326}{783}$

Sw Fr 783

(296)

Sw Fr 21,095
The Early Papers on Diffraction of $X$-rays by Crystals accounts are shown in Table 7. No expenses were incurred and the deficit on this fund account has been reduced over the triennium.

The Molecular Structures and Dimensions accounts are shown in Table 8. Volumes 12,13 and 14 were published in 1981,1982 and 1983 respectively. The net sales income was used to reimburse the University of Cambridge for the publication costs and as much of the editing costs incurred by the Crystallographic Data Centre as possible. However, under the terms of the agreement between the Data Centre and the Union, the Union is not required to stand any financial losses which might arise. This is why the income and expenditure shown in the accounts balance exactly.
Table 9 summarizes the accounts for Fifty Years of Electron Diffraction which was published in 1981.

The Special Publications Fund accounts are given in Table 10. This fund was established in 1981 with the donation from the Japanese crystallographic community. This donation, together with small transfers from the General Fund and the journals accounts, has been used for the purchase of the computer. The fund account has now been closed.

Table 11 gives the accounts for the President's Fund, which was established in 1977. The fund was set up in memory of past Presidents. It is intended for use in emergencies and under special or difficult circumstances to help crystallographers to take part in the activities of the Union. 
Table 7. Early Papers on Diffraction of X-rays by Crystals

Income

Sale of copies

Less Publisher's commission

Excess of income over expenditure

Gain on fluctuations in rates of exchange

Accumulated balance at the end of the year

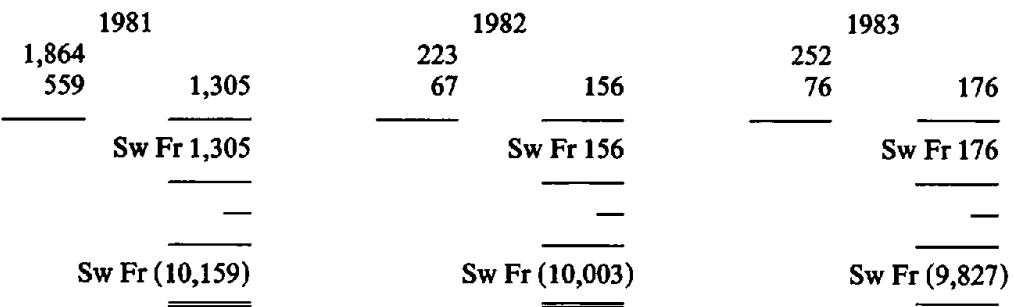

Table 8. Molecular Structures and Dimensions

Income
Sale of copies
Less Publisher's commission
Expenditure
Printing and binding
Miscellaneous expenses
Salaries
Administration expenses

Excess of income over expenditure

Gain on fluctuations in rates of exchange

Accumulated balance at the end of the year

\begin{tabular}{|c|c|c|c|c|c|}
\hline \multicolumn{2}{|c|}{1981} & \multicolumn{2}{|c|}{1982} & \multicolumn{2}{|c|}{1983} \\
\hline $\begin{array}{l}38,107 \\
10,373\end{array}$ & 27,734 & $\begin{array}{l}64,778 \\
17,450\end{array}$ & 47,328 & $\begin{array}{l}53,604 \\
14,296\end{array}$ & 39,308 \\
\hline $\begin{array}{r}14,384 \\
755 \\
11,384 \\
1,211\end{array}$ & 27,734 & $\begin{array}{r}30,325 \\
1,010 \\
14,790 \\
1,203\end{array}$ & 47,328 & $\begin{array}{r}36,237 \\
886 \\
1,230 \\
955\end{array}$ & 39,308 \\
\hline & nil & & nil & & nil \\
\hline & $(1,572)$ & & 142 & & (96) \\
\hline & 6,800 & & 6,942 & & 6,846 \\
\hline
\end{tabular}

Table 9. Fifty Years of Electron Diffraction

\section{Income \\ Sale of copies \\ Less Publisher's commission \\ Expenditure \\ Publication expenses}

Excess of income over expenditure

Gain on fluctuations in rates of exchange

Accumulated balance at the end of the year

Income

Donation from Japanese crystallographic community

Transfer from Acta Crystallographica lography

Expenditure

Cost of computer

Excess of income over expenditure

Gain on fluctuations in rates of exchange

Accumulated balance at the end of the year
Transfer from General Fund

Transfer from Journal of Applied Crystal-
1981

$$
\begin{array}{r}
10,519 \\
2,735 \\
\hline
\end{array}
$$

7,784

$$
14,314
$$$$
3,722
$$

1982

10,592
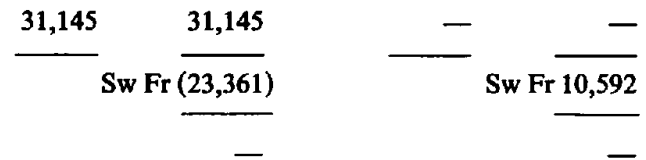

Sw Fr $\overline{(23,361)}$

Sw Fr $\overline{(12,769)}$

Sw Fr $\overline{(10,515)}$

1983

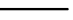

Table 10. Special Publications Fund
1981

59,821

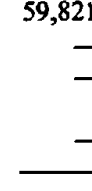

1982

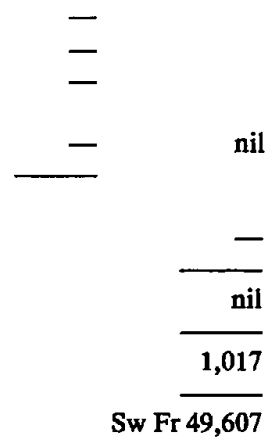

Sw Fr 49,607
1983

$$
\begin{array}{r}
11,505 \\
8,194 \\
3,311 \\
\hline
\end{array}
$$

Sw Fr $\overline{(49,607)}$

Sw Fr 59,821

$$
(11,231)
$$

nil nil 
Table 11. President's Fund

Income

Donations

Transfer from General Fund Account

\section{Expenditure}

Grants

Excess of income over expenditure

Gain on fluctuations in rates of exchange

Accumulated balance at the end of the year

Income

Subscriptions from Adhering bodies

Yield from investments and bank accounts

Grant from Unesco to ICSU

ICSU grant

Sale of sundry publications

Donation

Amount charged to:

Acta Crystallographica

Journal of Applied Crystallography

Molecular Structures and Dimensions

\section{Expenditure}

Administration

Subscriptions to ICSU/ICSU bodies

Executive Committee

Finance Committee

12th General Assembly \& Congress:

Travel grants

Commissions

Incidental expenses

Executive Committee

Publication of Report

13th General Assembly \& Congress:

Programme Committee

IUCr Representatives on other bodies

Expenses of Commissions

Sponsorship of meetings

Sundry publications

Transfer to Special Publications Fund

Transfer to President's Fund

Excess of income over expenditure

Gain on fluctuations in rates of exchange

Accumulated balance at the end of the year
1981

791

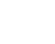

$$
791
$$

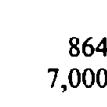

1982

7,000

1,611

Sw Fr 820

$(1,259)$

Sw Fr 5,448

$\underline{\underline{5,448}}$

Table 12. General Fund

\begin{tabular}{|c|c|c|c|c|c|}
\hline \multicolumn{2}{|c|}{1981} & \multicolumn{2}{|c|}{1982} & \multicolumn{2}{|c|}{1983} \\
\hline 89,114 & & 131,941 & & 129,940 & \\
\hline 131,382 & & 97,115 & & 137,180 & \\
\hline 20,680 & & 21,382 & & 30,714 & \\
\hline 15,710 & & 4,060 & & 4,260 & \\
\hline 22,179 & & 2,857 & & 538 & \\
\hline - & & 38,662 & & - & \\
\hline 32,100 & & 31,208 & & 31,511 & \\
\hline 10,700 & & 10,403 & & 10,503 & \\
\hline 1,211 & 323,076 & 1,203 & 338,831 & 955 & 345,601 \\
\hline 142,666 & & 138,703 & & 128,542 & \\
\hline 3,615 & & 3,817 & & 4,723 & \\
\hline- & & 16,333 & & 17,640 & \\
\hline - & & 7,641 & & 8,557 & \\
\hline 29,400 & & - & & - & \\
\hline 615 & & - & & - & \\
\hline 190 & & - & & - & \\
\hline 19,744 & & - & & - & \\
\hline - & & - & & 11,756 & \\
\hline - & & - & & 16,203 & \\
\hline 3,436 & & 6,106 & & 3,101 & \\
\hline - & & 4,354 & & 213 & \\
\hline 32,435 & & 4,836 & & 30,247 & \\
\hline 18,740 & & - & & - & \\
\hline - & & - & & 11,505 & \\
\hline - & 250,841 & 7,000 & 188,790 & - & 232,487 \\
\hline & Fr 72,235 & & r 150,041 & & r 113,114 \\
\hline & $(63,408)$ & & 9,024 & & $(7,565)$ \\
\hline & 274,330 & & 433,395 & & 538,944 \\
\hline
\end{tabular}

In 1982 it was decided to increase the balance in the fund by a contribution of Sw Fr 7000 from the General Fund.

Table 12 summarizes the accounts for the General Fund of the Union. This is the fund which is available for the support of scientific activities other than publications. In 1981 Sw Fr 29400 was given in travel grants to the XII Congress, with a further Sw Fr 32435 in support of other meetings. In 1982 only Sw Fr 4836 was needed for support of meetings, and donations totalling Sw Fr 38662 were gratefully received from the organizers of the XII Congress and the associated School on Crystallographic Computing and Meeting on Crystalline Deposits in Human Tissues. In 1983, Sw Fr 30247 was used for the support of meetings. Additional funds were spent on support of Union representatives on other bodies. The expenses of the Finance Committee, established in 1981, were Sw Fr 7641 in 1982 and Sw Fr 8557 in 1983. The 1983 meeting of the Programme Committee for the XIII Congress cost Sw Fr 16 203. In 1982 the Commission on Charge, Spin and Momentum Densities received financial support to enable them to meet. Other 
Table 13. Comparison of budget and accounts for the years 1981-1983 inclusive

\begin{tabular}{|c|c|c|c|c|c|c|}
\hline Income & \multicolumn{2}{|c|}{ Budget } & \multicolumn{2}{|c|}{ Accounts } & \multicolumn{2}{|c|}{ Difference } \\
\hline Subscriptions from Adhering bodies & 319500 & & 350.995 & & +31495 & \\
\hline Yield from investments and bank accounts & 191,700 & & 365,677 & & $+173,977$ & \\
\hline Subventions from Unesco and ICSU & 68,160 & & 96,806 & & $+28,646$ & \\
\hline Sale of sundry publications & 46,860 & & 25,574 & & $-21,286$ & \\
\hline Donations & - & 626,220 & 38,662 & 877,714 & $+38,662$ & $+251,494$ \\
\hline Expenditure & & & & & & \\
\hline Administration & 361,248 & & 291,622 & & $-69,626$ & \\
\hline Subscriptions to ICSU and bodies of ICSU & 11,289 & & 12,155 & & +866 & \\
\hline Scientific meetings & 102,240 & & 118,493 & & $+16,253$ & \\
\hline Administrative meetings & 112,890 & & 94,314 & & $-18,576$ & \\
\hline Sundry publications & 42,600 & & 18,740 & & $-23,860$ & \\
\hline Transfer to President's Fund & - & & 7,000 & & $+7,000$ & \\
\hline Loss on fluctuations in rates of exchange & - & 630,267 & 61,949 & 604,273 & $+61,949$ & $-25,994$ \\
\hline Favourable variant from budget & & & & & Fr 277,488 & \\
\hline Estimated deficit & & & & & 4,047 & \\
\hline Excess of income over expenditure & & & & & Fr 273,441 & \\
\hline
\end{tabular}

Commissions were able to meet at various scientific conferences without the need for financial assistance from the Union.

Table 13 compares the General Fund accounts for the triennium with the budget approved by the Twelfth General Assembly, converted to Swiss Francs at the exchange rate in operation at the time of that General Assembly (US \$1 = Sw Fr 2-13). It shows a favourable variant of Sw Fr 277488 from the budget.

Allowing for the budgeted loss of Sw Fr 4047, the actual excess of income over expenditure was Sw Fr 273 441. The major difference was the yield from bank deposits and investments which was much higher than estimated, mainly because the substantial income received from the journals, for the reasons stated earlier in this report, enabled the Union to place substantial funds on deposit with its banks. It has therefore been possible to re-establish a reasonable reserve against the liabilities of the Union's large publishing commitments. Since virtually all these funds are in currencies other than Swiss francs, the yield from bank accounts is very prone to influence by fluctuations in exchange rates. The extra subscription income arose from the General Assembly's decision to increase the unit contribution to Sw Fr 890.

Additional funds were received from the Unesco Subvention and grants from ICSU. The sales income and the cost of incidental publications were much lower than in the budget because only one edition of the World Directory of Crystallographers was published. The administrative expenses of the Union have not increased as much as estimated mainly because of the dramatic fall in the rate of inflation in the UK since 1980. It has been possible to increase the support for scientific meetings whilst restricting the costs of administrative meetings. The main variation in the expenditure was the Sw Fr 61949 loss on fluctuations in rates of exchange, sustained mainly in 1981.

Tables 14 and 15 give a comparison of the Balance Sheet of the Union at the beginning and the end of the triennium. Table 14 shows the fund accounts, whilst Table 15 shows the distribution of the assets. The value of the stocks of unsold copies of the journals and other publications is not included in the assets.

In spite of losses on fluctuations in rates of exchange, the total assets of the Union have nearly doubled over the triennium.

The assets at 31 December 1983 include an amount of Sw Fr 413694 for debtors. The largest parts of this relate to amounts due at that date in respect of the publishing operations during 1983, from Munksgaard for the journals and from Reidel for the other publications including Structure Reports and International Tables. These amounts, due in 1984, and the great majority of the other amounts under debtors and creditors, have since been settled.

The Union's bank accounts are held with the Union Bank of Switzerland in Geneva, the Amsterdam-Rotterdam Bank NV in Groningen, the Bankers Trust Company in New York and the National Westminster Bank in Manchester and Chester. Substantial amounts in US dollars and pounds sterling have been placed on high-yield deposit with the banks in the Netherlands, the UK and the USA. The investments are government bonds of Sw Fr 18000 and $£ 100000$.

As an association incorporated in Switzerland, the Union is exempt from Swiss Federal and Geneva Cantonal Tax. Under the terms of the United Kingdom Switzerland Double Taxation Agreement 1967, whilst present circumstances obtain, all income arising within the United Kingdom is not subject to United Kingdom tax.

\section{Appendix C: Use of the donation from the Japanese crystallographic community}

As reported at the previous General Assembly in Ottawa, the Japanese crystallographic community had collected 7000000 Yen (about $\$ 35000$ ) as a donation towards the Union's publications. With the help of this generous donation a microcomputer with 384 Kbytes of memory and 15 Mbytes of hard disc storage (with magnetic cartridge tape back-up) has been installed in the Union office at Chester. This computer enables the progress of all papers 
Table 14. Balance Sheet, Fund Accounts

Acta Crystallographica

Journal of Applied Crystallography

Structure Reports

International Tables

Fifty Years of $X$-ray Diffraction

Escher Drawings

Early Papers

Molecular Structures and Dimensions

Fifty Years of Electron Diffraction

Special Publications Fund

General Publications

Total of publication accounts

General Fund

President's Fund

Total accumulated balance

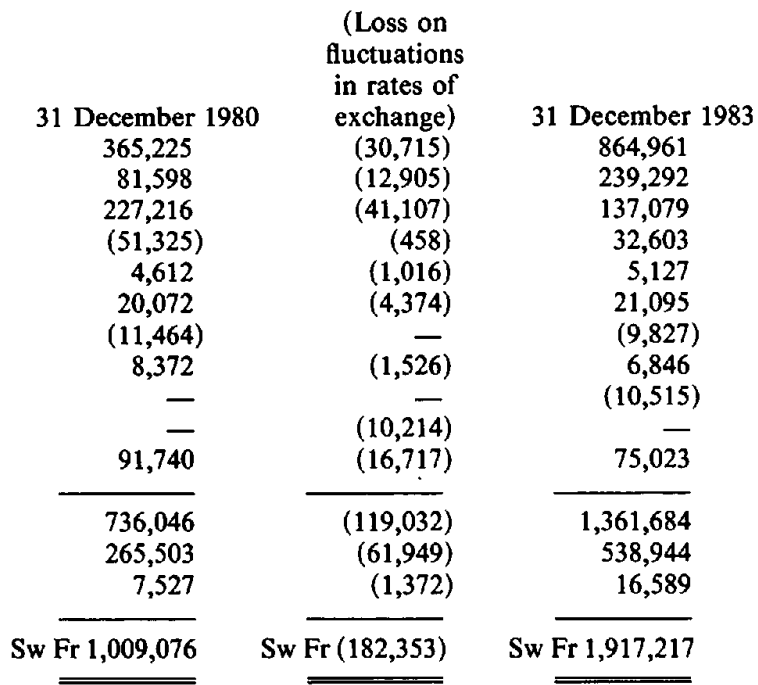

(Loss on

$41,107)$

$(458)$

$(4,374)$

$(1,526)$

$10,214)$

$(16,717)$

$(19,032$

$(61,949)$

w Fr $(182,353)$ from the Japanese crystallographic community, was formally placed in service on 1 January 1984'.

\section{Appendix D: Reports of the Commissions of the Union}

\section{(a) Commission on Journals}

Acta Crystallographica and the Journal of Applied Crystallography have been published on schedule throughout the last triennium. A major change was the division in 1983 of Acta Crystallographica, Section B, into two new Sections with new subtitles for all three. Section A, Foundations of Crystallography, welcomes papers concerned with basic developments in all areas of crystallography; Section B, Structural Science, is for structurally based papers from disciplines throughout the natural sciences; Section $\mathrm{C}$, Crystal Structure Communications, is for reports of crystal structure determinations. The total number of papers in Acta Crystallographica was $18.5 \%$ fewer than in the previous triennium, that in Journal of Applied Crystallography was $17 \cdot 2 \%$ fewer. Papers from 65 different countries have been published. Mean publication times between published acceptance and nominal publication dates are now at or below their historical minima and range from 4.3 months for Section C to $5 \cdot 3$ months for Section B and the Journal of Applied Crystallography.

An increase of $126 \%$ in regular and $48 \%$ in individual subscription rates for Acta Crystallographica and the Journal of Applied Crystallography, together with a series of measures to reduce unnecessary expenditures, was required in this triennium in order to place the production of our journals on a sound economic basis. This large increase was matched or exceeded by several other major publishers. Our total number of subscribers decreased in the triennium by $15.6 \%$ for Acta Crystallographica and $8.2 \%$ for the Journal of Applied Crystallography. Comparable decreases have been reported by other publishers. The regular subscription rate in 1982 for Acta Crystallographica corresponds to $2 \cdot 6$ US cents/ 1000 characters and for the Journal of Applied Crystallography to 4.0 US cents/ 1000 characters: a recent survey, by the American Mathematical Society in office, with the following wording: 'The first IUCr office computer, purchased with the help of a generous donation

roughout the journal production process to be monitor index, chemical name index, author index and formula of a balance sheet and accounts, comparable to those published in the annual Executive Committee reports [cf. Acta Cryst. (1984), A40, 78-85]. An engraved wall plaque commemorating the Japanese gift has been placed in the Chester

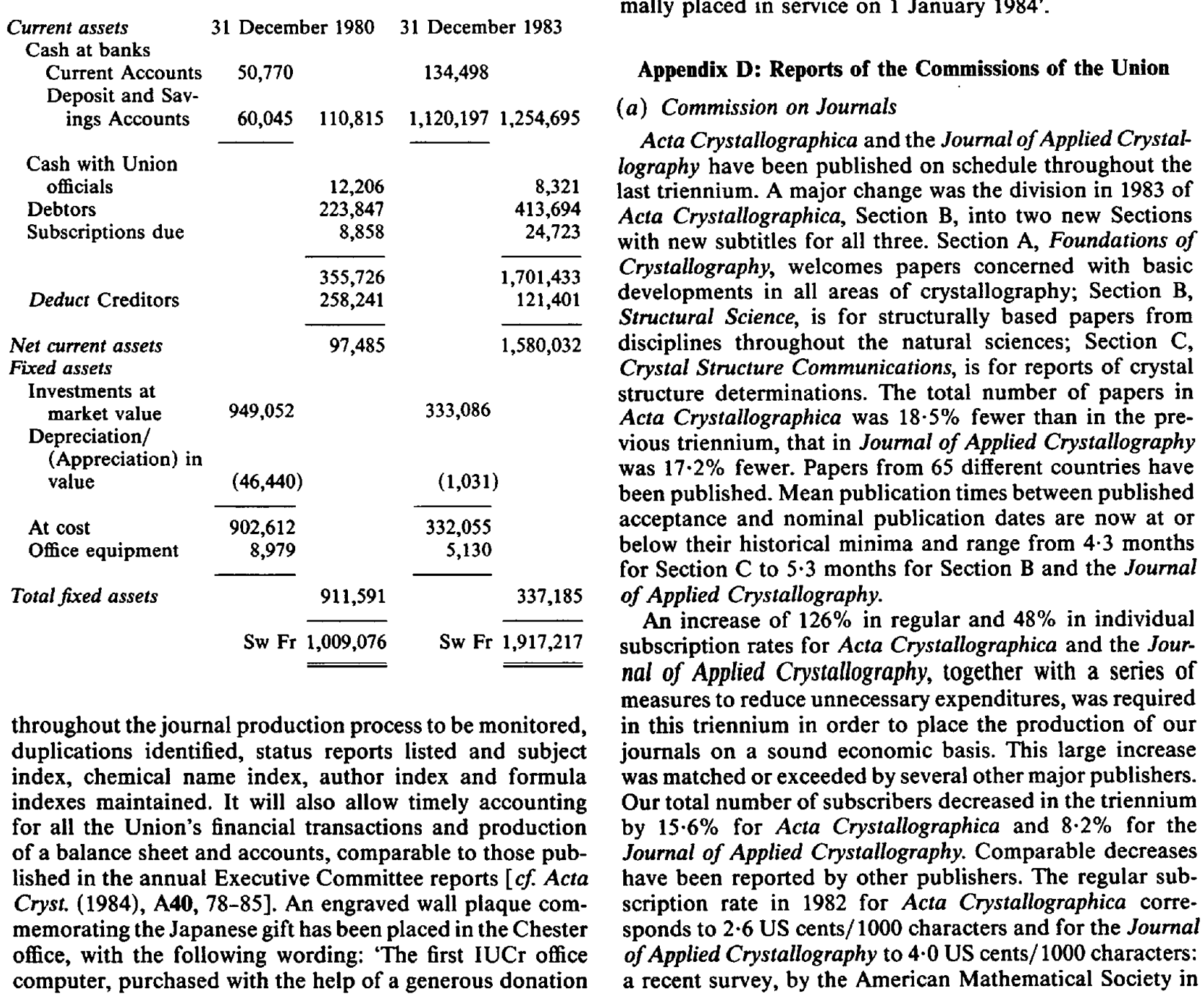


Table I. Sales of International Tables

\author{
Volume \\ Date of publication \\ Dates of reprinting \\ Number of copies sold: \\ up to 31 December 1983 \\ between 1 January 1981 and 31 December 1983 \\ Stock at 31 December 1983
}

$\begin{array}{ccccc}\text { I } & \text { II } & \text { III } & \text { IV } & \text { A } \\ 1952 & 1959 & 1962 & 1974 & 1983^{*} \\ 1965,1969,1977 & 1967,1972 & 1968,1983 & - & - \\ & & & & \\ 9501 & 8497 & 7755 & 3319 & 1186 \\ \text { nil } & 247 & 312 & 391 & 1186 \\ \text { nil } & 120 & 310 & 648 & 179\end{array}$

* A reprint is scheduled for the spring of 1984. their Notices [(1983). 30, 715-719], of primary typeset mathematical research journals without page charge in 1982 shows a range from $1 \cdot 1$ to 35.0 with an average subscription rate of 6.5 US cents/ 1000 characters.

A minicomputer with $384 \mathrm{Kbytes}$ of memory and 15 Mbytes of hard disc storage, cartridge tape back-up, six VDU terminals and two printers has been installed in the IUCr offices at Chester. In addition to handling the accounts of the IUCr, it will be used initially in maintaining journal production records, in checking for the possible submission of duplicate structures, and in producing the journal indexes. The first quinquennial index thus produced will save approximately the total cost of the minicomputer.

G. A. Jeffrey retired and D. H. Templeton resigned from the Commission during this triennium, while appointments included C.E. Bugg, J. Drenth, J. A. Ibers, M. Nardelli, C. E. Nordman, R. Norrestam, S. E. Rasmussen and $\mathrm{H}$. Steinfink. The Commission was most ably supported throughout the period by the dedicated work of $\mathrm{D}$. W. Penfold, Technical Editor and Computer Manager, J. E. Derry, Deputy Technical Editor, M. H. Dacombe, Assistant Technical Editor, S. E. Lowe and A. J. Sharpe, Editorial Assistants, and J. I. Heywood and M. J. Robinson, Secretaries.

18 April 1984.

S. C. ABRAHAMS, Chairman

M. HART, Co-Chairman

\section{(b) Commission on Structure Reports}

The three-year period has once again involved steady co-editorial and editorial work in both $A$ and $B$ volumes.

The following volumes have been published: Volume 36 (Ten-Year Index for 1961-1970), Volumes 46A, 47A (TenYear Index for 1971-1980), 48A, 44B, 45B. Volume 46B should appear later in 1984. Co-editorial work is near completion on Volumes $49 \mathrm{~A}$ and $48 \mathrm{~B}$, and continues on $49 \mathrm{~B}, 50 \mathrm{~A}, 50 \mathrm{~B}, 51 \mathrm{~A}$ and $51 \mathrm{~B}$.

The number of organic reports in the $B$ volumes continues to increase, and is now more than 2500 papers a year.

27 April 1984.

G. FERGUSON, Chairman

(c) Commission on International Tables for Crystallography

At the General Assembly of the International Union of Crystallography held in 1981, the Chairman of the outgoing Commission, Professor Th. Hahn, announced the completion of the editorial work on Volume A: Space-Group Symmetry. After selection of a publisher (D. Reidel, Dordrecht, The Netherlands) and a final check it went to press in June 1982. No new Commission was elected in 1981, but Pro- fessor Hahn and his colleagues continued the complex task of seeing Volume A (xvi +854 pages) through the press; it was published in November 1983. Both the old Volumes II-IV and Volume A have sold well (Table I). The stock of Volume I has been exhausted (much of it has been superseded by Volume A); Volume A will be reprinted; and it may be necessary to reprint Volume II.

In 1982 the Executive Committee discussed the problem of producing further volumes, and appointed Professor U. Shmueli as Editor of Volume B: Reciprocal Space, and Professor A. J. C. Wilson as Chairman of the Commission and Editor of Volume C: Mathematical, Physical and Chemical Tables. No further members of the Commission were appointed, so that during 1982-1984 the Commission has consisted only of the Editors and the ex-officio members.

The Editors began work officially on 1 January 1983, though unofficially a great deal of preparatory work had already been done. This included, in particular, development of much of the software required for automated generation of tables for the Chapter Symmetry in Reciprocal Space in Volume B and correspondence concerning computerized typesetting methods. During April/May 1983 the Editors met in Tel Aviv and prepared a lengthy memorandum, including draft Tables of Contents for the two volumes, which was circulated to the Executive Committee, the National Committees, and widely elsewhere. This circulation generated much constructive criticism and offers of help, particularly from several of the Commissions of the Union.

The Editors met again in Cambridge in August 1983, revised the Tables of Contents, and began issuing invitations to prospective authors of the various Parts, Chapters, and Sections. Discussions by the Editor of Volume $B$ in the course of ECM-8 at Liège were of considerable help in choosing authors. In September, however, the Editors were asked to suspend invitations until the proposed authors had been approved by the Executive Committee; obtaining this approval is introducing delays of some months. At the time of writing this report (February 1984) authors have been approved and have accepted invitations to contribute rather more than half the bulk of the Volumes; several outlines and a couple of draft sub-sections have been received.

The Commission intends to hold both open and closed sessions during the XIII Congress. It is hoped to have outlines from all authors so far invited ready for discussion at that time. The Editors have received a proposal that there should be a further Volume D (Physical Properties of Crystals), and this proposal will be considered at the open sesssion.

19 March $1984 . \quad$ A. J. C. WILson, Chairman 
(d) Commission on Biological Macromolecular Crystallography (subsequently renamed Commission on Biological Macromolecules)

The Commission was established by the XII General Assembly in August 1981 at Ottawa and held its first meeting there on 21 August. It was decided that, at this time, the Commission should concern itself primarily with the quality of suitable scientific meetings and journals.

The enormous change in the representation of biological work at the Ottawa Congress as opposed to the Warsaw Congress was greatly appreciated. In order to assure a continuation of this trend, T. L. Blundell agreed to have his name proposed to the Programme Committee for the Hamburg Congress.

The Commission met during the workshop on Crystallography of Molecular Biology in Erice in June, when most of the time was dedicated to topics for the XIII Congress. At the workshop there was also an open discussion on the merits of starting a new journal but the consensus was that there were already sufficient other journals covering the field.

The current problems with publication in Acta Crystallographica of material relevant to the concerns of the Commission were recognized. A lengthy proposal for changes to Acta Crystallographica policy was drawn up and subsequently sent to the Commission on Journals. The major thrust was for the appointment of a special editor with knowledge and experience of macromolecular biology to Acta Crystallographica.

The Commission was pleased to note a variety of excellent international meetings devoted to macromolecular structure and its function.

Compiled by the Executive Secretary from annual reports by $M$. Rossman, Chairman.

May 1984.

\section{(e) Commission on Charge, Spin and Momentum Densities}

The Commission has continued to sponsor and coordinate studies of many aspects of electron-density distributions relevant to the activities of the crystallographic community.

\section{Sagamore VII Conference}

Traditionally, one of the primary functions of the Commission is the organization of the triennial Sagamore research conferences. Sagamore VII was held in Nikko, Japan, in August 1982 under the chairmanship of Professor Y. Saito. It attracted approximately 120 active participants, one third of whom came from outside Japan. The six-day conference was a healthy mixture of formal plenary lectures, poster presentations and informal discussions.

The Commission met during the conference to consider, among other things, the next conference in this series. It was resolved that Sagamore VIII will be held in Sweden, 28 July-3 August 1985, at Sanga-Saby, under the chairmanship of Professor I. Olovsson.

\section{Projects}

(a) Oxalic acid. Four sets of X-ray measurements and five sets of neutron data taken on different crystals of oxalic acid dihydrate have been analysed. Thermal parameters, atomic positions and difference density maps have been compared with three theoretical models. All the data sets show chemically significant features, although the theories show larger deformations associated with the lone pairs. A report has been prepared by Professor P. Coppens who, along with Professor E. N. Maslen, coordinated the project; it is now in print [Acta Cryst. (1984), A40, 184-195].

(b) Vanadium. Metallic vanadium was chosen for a comprehensive electron-density study with $X$-ray and neutron diffraction techniques and $\gamma$-ray Compton scattering. It was chosen because there was early evidence of a difference between the electron-density anisotropy in position and momentum space and uncertainty about the orbital contribution to the neutron magnetic scattering cross section. The experimental phase of this project, which is being coordinated by Dr P. J. Brown, is now complete and the results will be reviewed in open forum at the XIII Congress. It is hoped that a consistent interpretation of the different density distributions can be attempted.

(c) Data bank. Following the Commission's initiative, a data bank for X-ray diffraction data used in charge-density studies has been established by Professor M. Burzlaff at the University of Erlangen-Nurnberg. An Advisory Committee, which includes three members of the Commission, has been set up and first met in 1981.

(d) Correlated form factors. Calculations principally for the first-series transition elements are being performed by Professor P. Coppens, Professor V. H. Smith and others. The Commission believes that it is important for correlated form factors to be available to crystallographers.

(e) Publications on charge density. The Commission has, upon request, provided the Editors of Acta Crystallographica with an initial set of guidelines for the acceptance of charge-density studies for publication. An ad hoc committee under the chairmanship of Professor P. Coppens has been set up to consider the matter further.

(f) Hamburg Congress. The Commission is directly involved in planning two microsymposia for the meeting, one on vanadium [see (b) above] and another on charge, spin and momentum densities.

The Commission has had preliminary discussions on charge-density projects concerned, for example, with the topics of light metals and the techniques of electron coincidence spectroscopy. It is hoped to launch projects in these areas after further discussions at the XIII Congress.

8 February 1984.

M. J. CoOPER, Chairman

\section{(f) Commission on Crystal Growth and Characterization of Materials}

The main activities of the Commission in the last three years have been the organization of two international schools on materiats science and energy conversion in third world countries. The aim of these activities was the active participation of the IUCr in the science and technology transfer to the third world and the expansion of the field of crystallography to the materials science of electronic materials. Both schools were successful and one can only hope that, although a very strong commitment from the Commission is necessary, it will be possible to continue this scientific policy in the future.

The two schools organized by the Commission were:

(a) 'International School on Synthesis, Crystal Growth and Characterization of Materials for Energy Conversion and Storage', New Delhi, 12-23 October 1981. The school 
was co-directed by E. Kaldis and Krishan Lal. The Commission acted as programme committee, selecting the 28 lecturers. The lectures were attended by 140 participants from university and industrial laboratories. An optimal selection of lecturers, the superb local organization and the high scientific standard and great interest of the participants contributed to a very successful school.

(b) 'International School on Materials Science and Solar Energy', Cairo and Alexandria, 18 March-1 April 1983. Director of the school was E. Kaldis and the General Secretary and Chairman of the Egyptian Organizing Committee in Cairo was S. Arafa, who succeeded in doing an excellent job. Although the scientific needs of Egypt are quite different from those of India, the lecturers were able to adapt to the needs of the audience and the school was very successful.

Further to these activities, the Commission supported the 'Fifth International Summer School on Crystal Growth', Davos, Switzerland, 3-10 September 1983, and 'ICCG-7', which took place immediately after in Stuttgart, also the 'International Conference on Crystal Growth and Characterization of Polytype Structures' to be held in Marseille, 3-6 July 1984.

18 May 1984.

E. Kaldis, Chairman

\section{(g) Commission on Crystallographic Apparatus}

The Commission mourns the death of its Chairman, Sixten Abrahamsson. Commission activities for the triennium are outlined below.

\section{Microdensitometer Project (S. Abrahamsson,}

\section{P. Kierkegaard, O. Lindqvist and L. Sjolin)}

The results of the first phase of this project have been published [J. Appl. Cryst. (1981). 13, 318-337] and the second phase of the experiment, a comparison between data from the same crystal recorded using film and diffractometer techniques, was reported at the XII Congress. The preparation of a paper on this comparative study is in hand.

2. Survey of Film Characteristics (M. Elder and O. S. Mills)

The final report of this survey was reported as paper 16.X-02 at the XII Congress. An analysis was made of 23 films which exhibited relative speeds ranging from 1.4 to 0.1 compared with the previously available Ilford Industrial $G$ as $1 \cdot 0$. No written report has been produced.

\section{X-ray Attenuation Project (D. C. Creagh)}

This project involved the cooperation of 23 laboratories situated in 15 countries. These laboratories performed measurements on three sets of sample material, singlecrystal silicon, polycrystalline copper and pyrolytic graphite. The detailed photon scattering from each sample is different and the responses of the different experimental techniques to sample type have been correlated. Details of the project will be contained in papers being prepared at present in collaboration with J. H. Hubbell of the US National Bureau of Standards. A paper on the project will be presented as paper 06.06 at the XIII Congress.

\section{Polarization Radiation Survey (L. D. Jennings)}

The results of this survey have been published [Acta Cryst. (1984). A40, 12-16]. It is recommended that the polarization ratio $K$ of an apparatus be measured directly wherever possible, although methods for estimating $K$ are also given for those situations in which a direct measurement is not possible.

\section{Radiation Safety (S. Martinez Carrera)}

The extremely diverse set of regulations which pertain in the many countries adhering to the IUCr makes the formulation of a universal set of rules which will satisfy the legal requirements for each country extremely difficult. The closed meeting of the Commission will discuss this problem when it meets at the XIII Congress.

\section{Accurate Determination of Diffractometer Intensities (H. Hope)}

A disappointing response of laboratories to collaborate in this project has caused modifications to be made to the project plan. Analyses of data arising from preliminary investigations indicate that far too much time is taken for intensity measurements in routine structure determinations, a conclusion which has some significance for those structures subject to radiation damage.

\section{Profile Analysis (J. Črmák)}

This project is considered by Commission members to be of some importance because of recent improvements in $\mathrm{X}$-ray source and $\mathrm{X}$-ray detector technology. There have been, however, some difficulties in the organization of the project but it is hoped that the project may be commenced in the forthcoming year.

\section{Intensity Meeting (P. Kierkegaard)}

An open Commission meeting on 'Determination of Accurate Intensities and Structure Factors' has been arranged for the XIII Congress. The meeting will address the problems of the production of accurate data and the use of accurate structure factors.

16 May 1984.

D. C. Creagh, Chairman

\section{(h) Commission on Crystallographic Computing}

\section{Closed Meetings of the Commission}

The Commission met at two separate sessions during the triennium. A series of meetings were held at the XII Congress in Ottawa to plan Commission activities for the triennium. These included plans for the locality and dates of future computing schools (see below), and for finding better methods of informing users on the availablity and status of crystallographic software. Some members of the Commission were also available at the 1983 Kyoto Computing School to discuss plans for a 1984 computing school, a proposed Computer Program Abstract section for Journal of Applied Crystallography (see below), and to select topics for the open Commission meeting at the XIII Congress.

\section{Publication of 1981 Ottawa Computing School Proceedings}

The proceedings of the 1981 'International Summer School on Crystallographic Computing' held at Ottawa have been published by Oxford University Press under the title Computational Crystallography. Dr D. Sayre, who organized the Ottawa school, is the editor of the proceedings. The Commission greatly appreciates the work of Dr Sayre in running this school. He demonstrated that it is possible to hold a successful school, publish its proceedings, and still return revenue to the IUCr. 


\section{The 1983 Kyoto Computing School}

The 1983 'International Summer School on Crystallographic Computing' was held in Kyoto, Japan, 18-26 August 1983. The school was organized by the Commission and the Crystallographic Society of Japan, and run under the auspices of the IUCr and ICSU. The school was supported financially by a large number of professional and commercial agencies.

This was the first IUCr computing school to be held in the Asian/Pacific area and the second to be run independently from an IUCr Congress (the first was in Bangalore in 1980). The lecture programme covered a broad range of crystallographic applications, most with a strong macromolecular flavour. Major topics included data measurement and error treatment, solution methodology (direct and indirect), software packages and databases, refinement and phase extension, computer graphics, powder analysis, precision electron-density studies and electron diffraction.

The programme structure placed particular emphasis on the use of work sessions. The approximately 30 lectures were given in the mornings, leaving most afternoons for parallel 90-minute work periods. These were limited to groups of 10-20 participants. Since English was not the first language of most participants these sessions were of particular importance. The work sessions proved to be the real kernel of the school and the level of effort input by both lecturers and participants ensured their success. Language considerations also necessitated a particularly high level of lecture presentation and documentation. This is reflected in the detailed lecture notes which are due to be published shortly as a book entitled Methods and Applications in Crystallographic Computing by Oxford University Press.

With over 150 participants and 30 lecturers from 15 different countries, the school organization involved considerable local support. Participants were housed at two hotels within walking distance of each other and these also served as the lecture venues. Professor T. Ashida was the Chairman of the Local Organizing Committee and deserves special credit for the smooth running of the school. All Commission members are to be thanked for their assistance in organizing the school programme.

\section{The 1984 Mulheim Computing School}

The 1984 pre-Congress 'International Summer School on Crystallographic Computing' will be held at the Max Planck Institute in Mulheim, 30 July-8 August. Professor H. Burzlaff is the Programme Chairman. The Commission is not directly responsible for the organization of the school but has assisted in the selection of school topics and lecturers. The school has placed particular emphasis of the application of crystallographic techniques and will employ the extensive computer facilities at the Institute for the workshop sessions.

\section{Appointment of a Consultant to the Commission}

Dr A. Larsen was appointed as a consultant to the Commission for the specific purpose of assisting invited lecturers to the Kyoto Computing School with their funding applications. Dr Larson has had considerable experience in this area and was responsible for organizing travel funds for North American lecturers to the 1980 Bangalore School.
6. Proposed Computer Program Abstract Section for Journal of Applied Crystallography

The Commission has been concerned for some time at the lack of a convenient and up-to-date method of communicating information on crystallographic computer software to users. The World List of Crystallographic Programs is no longer available because it proved too difficult to maintain. The concept of an IUCr Clearing House of crystallographic software (along the lines of the now-defunct NRCC project in North America) was considered but deemed to be unworkable without independent funding and a large manpower effort. The Commission is currently considering a special abstract format for publishing software information in the Journal of Applied Crystallography. A draft abstract has been circulated and it is expected that a recommendation will be made to the Executive Committee following the Commission meetings in Hamburg.
7 February 1984.
S. R. HALL, Chairman

\section{(i) Commission on Crystallographic Data}

The Commission sponsored two open Commission meetings at the Congress in Ottawa in 1981 and is planning two others for the Hamburg Congress in 1984 ('Obtaining Structural Data from Computer Databases' and 'The Role of Crystallographic Data in Systematic Chemistry'). Several closed Commission meetings were held during the Ottawa Congress and others are planned for Hamburg.

The Commission, jointly with the Commission on Crystallographic Computing, has approved a Standard Crystallographic File Structure to permit the easy transfer of crystallographic data between programs and laboratories. The standard has been published [Acta Cryst. (1983). A39, 218-224] and has already been adopted by a number of programmers (e.g. it is available in $X T A L)$.

A task force has been established to recommend the correct use and meaning of various key words that might be used in crystallographic data retrieval and it will report in Hamburg.

A set of recommendations for the publication of crystal structures has been circulated to the editors of non-Union journals that frequently publish crystal structures and has been favourably received.

The Commission is recommending the use of the reduced cell adopted by Crystal Data as a useful means of determining the proper space group and cell during preliminary investigations of a crystal structure.

Under current discussion are a number of ideas and problems related to the dissemination of crystallographic data. These involve new methods of publishing crystal data (unit cells) (jointly with the Commission on Journals), standardized descriptions for crystal structures to make comparison easier, direct computer transfer of structural data between authors, journals and databases, improving the accessibility to deposited data, and ensuring adequate accessibility to the structural databases that are becoming an important crystallographic tool.
14 February 1984.
I. D. BROWN, Chairman

\section{(j) Commission on Crystallographic Nomenclature}

The primary activity of the Commission during the last three years has been its interaction with the two $A d$ hoc Committees appointed under the procedures outlined in Acta Cryst. (1979). A35, 1072. The first report, on the 
Nomenclature of Polytype Structures, has been accepted both by the Commission and the Executive Committee and will appear in Acta Cryst. (1984). A40, 399-404. The second report, on the Nomenclature for Bravais Lattice Types, Crystal Families and Arithmetic Classes, is now at an advanced stage of preparation [Acta Cryst. (1985). A41, 278-280]. Membership of the Ad hoc Committees is given in Acta Cryst. (1980). A36, 1077; (1981). A37, 928. The nomenclature proposed by these reports, on publication in our journals, is thereafter binding on all IUCr publications. Correspondence has been exchanged with a number of international bodies, including the IUPAC Commission on Nomenclature of Inorganic Chemistry and their Interdivisional Committee on Nomenclature and Symbols, the Committee of Editors of the Biochemical Journals of IUB and several National Committees.

March 1984.

S. C. Abrahams, Chairman

(k) Commission on Crystallographic Studies at Controlled Pressures and Temperatures

The Commission planned an open Commission meeting for the Hamburg Congress. After discussions it was decided to devote the whole session to the use of synchrotron radiation for crystallographic studies at controlled pressures and temperatures. Four invited speakers were selected to review the general problems concerning the use of synchrotron radiation for these studies as well as the activity in this field around the world.

16 May 1984.

B. BURAS, Chairman

\section{(l) Commission on Crystallographic Teaching}

The activities of the Commission during the last three years can be classified under the following headings:

\section{Commission Meetings}

During the XII Congress in 1981, the Commission held three business meetings and organized an open session on 'Teaching Crystallography for Materials Scientists'. Similar meetings are scheduled during the XIII Congress in August 1984, including an open Commission meeting on 'Teaching Crystallography for Today's Sciences'.

\section{The Pamphlet Project}

The Commission has undertaken to produce inexpensive pamphlets on different topics in crystallography, to assist in teaching the subject under different parent disciplines. Professor C. A. Taylor is the editor for the project. The first ten pamphlets produced by the Commission have sold more than 6000 copies in aggregate making the project selfsufficient. Another nine pamphlets on different crystallographic topics, duly refereed and edited, are presently in the press and should be available at the Hamburg Congress. The pamphlets are published for the Union by the University College Cardiff Press, PO Box 79, Cardiff CF1 1XL, UK, and cost $£ 0.95$ each. Two hundred sets of the first ten pamphlets have been made available for distribution in developing countries through Unesco.

\section{Crystallographic Booklist}

In collaboration with the Commission on Journals a comprehensive list of crystallographic books published the world over during 1970-1981, in different languages, was prepared by Dr J. H. Robertson and has been published in J. Appl. Cryst. (1982). 15, 640-676. Classified into different subject areas, the list contains nearly 1200 titles and adds to the earlier lists published by the Commission in 1965 (edited by Helen Megaw) with supplements published during 1966 and 1972.

\section{International Schools}

After its initial experience of two schools on teaching of crystallography, held at Erice, Sicily, in 1977 and 1980, the Commission decided to embark on a programme of conducting international schools in developing countries of Latin America, Asia and Africa. The first such school on 'Teaching Crystallography for Materials Science' was organized by the Brazilian National Research Council (CNPq) at the University of Campinas, São Paulo, Brazil, 18-27 July 1983, with Professor S. Caticha Ellis as the Director of the school. The Commission acted as the International Programme Committee. Seventeen lecturers drawn from 10 different countries and 127 participants drawn mostly from the Latin American countries participated. It was the first such school organized in Latin America on the teaching of crystallography and evinced great interest and enthusiasm among the participants. The Commission is now looking for suitable venues for similar schools in Africa and Asia.

\section{Exhibition of books and teaching aids}

On behalf of the Commission, Professor H. von Philipsborn is helping to organize such a non-commercial exhibition at the XIII Congress.

\section{Historical Atlas of Crystallography}

On behalf of the Commission, Professor J. Lima-de-Faria has compiled a historical atlas of the development of crystallography, for the use of teachers as well as historians of science. Since the atlas is too large to be printed as a pamphlet, it is proposed to consider alternative avenues for its publication in consultation with professional historians.

12 April 1984.

P. KRISHNA, Chairman

\section{(m) Commission on Electron Diffraction}

This Commission traditionally consists of three groups based on the disciplines of HEED (high-energy electron diffraction) GED (gas-phase electron diffraction) and LEED (low-energy electron diffraction), with four, three and two Commission members respectively. It seems very likely, at the time of writing this report, that an application will be made to increase the membership from 9 to 10 to take into account new topics which have come into prominence during this triennium. There are also five consultants, four of whom were appointed during the triennium, in order to obtain a broader subject representation, and to obtain help with Commission projects. These new consultantships have been very successful.

The work of the Commission has continued to be directed towards two goals. One is to provide an exchange of information, between disciplines and between countries or research centres, of current progress and new developments in the subject of electron diffraction, and the other is to publicize the capabilities of electron diffraction to the crystallographic community. Part of the need for this activity is due to the very rapid growth, particularly in the subject loosely defined as HEED, with respect to applications and technical advances in equipment. It is also worth 
mentioning that the subject as practised in the USSR has a slightly different emphasis, and it is hoped that the Commission has helped mutual understanding in this regard.

Specific activities during the triennium have related to Commission projects, evaluation of new topics and of recommendations with regard to standardizing notation and units, submissions to the Commission on International Tables and preparations for the XIII Congress. The main vehicle for communication within the Commission has been by means of the Chairman's Newsletters, of which there have been on average five or six annually at irregular intervals, as business demands.

\section{The Gas Electron Diffraction Information Service} (GEDIS)

This continues as the main newsletter of the GED, providing a comprehensive listing of authors and publications (compiled by Mutter, Seiter and Stark, Ulm/Donnau, Federal Republic of Germany).

\section{Commission Projects}

(a) Space-Group Project. This project has stimulated several review and research articles on the subject of spacegroup determination by electron diffraction, in particular from three participating laboratories in Bristol, Sendai and Melbourne. Since the subject has been advancing both theoretically and experimentally during the course of the project, the original idea of producing a definitive Commission document has been replaced by these review articles from laboratories, and has resulted in the substance for half a combined open Commission meeting at Hamburg, and to some input towards the planned volumes of International Tables.

(b) Electron Energy-Loss Spectroscopy (EELS). This topic has come into prominence, particularly during this past triennium, as an analytical tool, and is sufficiently established to be presented as a topic in Volume $\mathrm{C}$ of International Tables.

\section{Signs and Units in Electron Diffraction}

At the invitation of the Editor, A. J. C. Wilson, the Commission is responsible for a section on electron scattering in the forthcoming Volume $\mathrm{C}$, and for certain chapters in Volume B. A certain moral victory has been achieved in that the new series of volumes has dropped the specific word 'X-ray' from the traditional title.

\section{Preparations for Hamburg}

These preparations include two open Commission meetings on HEED and LEED, and an ad hoc meeting on GED. It is noted with some regret, however, that some other meetings clash with the IUCr Congress, including: 27th International Geological Congress (Moscow, 4-14 August); 8th European Congress on Electron Microscopy (Budapest, 13-18 August); 1st International Conference on the Structure of Surfaces (San Francisco, 13-16 August). These in particular cut across certain Commission interests. It may be to some extent avoidable in the future. It is obviously in our interests for members, thus warned, to take an early note of meetings planned for August in years of IUCr Congresses.

25 April 1984.

P. GoOdman, Chairman

\section{(n) Commission on Neutron Diffraction}

The Commission continues to sponsor a series of activities aimed at the collection and dissemination of information.

An important part of this has been the revival of the Newsletter in a new format, where the role of editor is taken in turn by members of the Commission. The first issue of this kind occurred at the end of 1982, the editor was Dr W. B. Yelon, and it contained updated values for scattering lengths and thermal neutron cross sections. This was followed by an issue in April 1983, which was edited by Drs G. H. Lander and M. H. Mueller, and which treated neutron scattering in North America. Then in October Dr Hicks edited an issue on Australia, Indonesia, Japan and China and a newsletter about the European activities is expected by early summer 1984 , this time with Dr B. T. M. Willis as editor.

In 1982 the compilation of magnetic form factors was reorganized by Dr J.-X. Boucherle, and a computer-based version has now been created. This contains, in concentrated form, references and comments on all known magnetic form factors obtained from neutron scattering techniques. Presently the list has been sent to all authors of papers in this field for comments, and it is then planned to update it at regular intervals. It has, however, not been possible to continue a similar compilation on magnetic structures. Another traditional activity of the Commission is the publication of an updated list of scattering lengths, and this was undertaken in a newsletter as mentioned above. Finally a new project concerning the comparison of singlecrystal diffractometers has been started, and is presently coordinated by Dr G. Heger.

An important part of the Commission activity has been the organization of the scientific programme for a 'Symposium on Neutron Scattering' in Berlin prior to the Hamburg Congress and which has Professor W. Saenger as local organizer. The programme will cover a diverse range of subjects such as magnetism, biology, chemistry and materials research, and there will be sessions on instrumentation and new sources. The Commission is also engaged in an open Commission meeting at the Hamburg Congress on spallation sources, and a microsymposium on crystal-structure solution and analysis by neutron powder techniques.

Finally, the Commission gave help to Professor A. J. C. Wilson in suggesting a series of subchapters concerning neutron techniques in the new Volume $\mathrm{C}$ of International Tables.

13 March $1984 . \quad$ M. S. LehMANN, Chairman

Appendix E: Reports of the Representatives on Scientific and Regional Associates

\section{(a) International Organization for Crystal Growth (IOCG)}

A new council has been elected by postal ballot. The new President of IOCG for the years 1983-1986 is Professor Kern, Director of the Institut de Cristallographie, Université Aix-en-Provence III and of the Centre des Mecanismes de la Croissance Cristalline (CNRS) in Marseille. In the same ballot an amendment of the constitution was accepted which underlines that the national meetings are subject to the laws and regulations of the host countries. This has 
been a formal obstacle for the participation of some countries in IOCG.

ICCG-7 was successfully held in Stuttgart in September 1983. The large European and Japanese participation overcompensated for the decreased participation from USA and USSR. The proceedings have been published by NorthHolland Publishing Company.

18 May 1984.

E. KALDIS, Representative

\section{(b) European Crystallographic Committee}

Report on the European Crystallographic Committee meetings held in Jerusalem on 1 September 1982 (during ECM-7), and in Liège, held on 9 August (during ECM-8).

Professor M. Nardelli deputized for Professor S. Ramaseshan, who was unable to attend either meeting. This is a summary of his reports to the Executive Committee. The Committee meetings were held as luncheon meetings, at Mount Scopus Campus in Jerusalem and at the University Campus, Liège.

1. A report on the organization of ECM-7 was presented by J. Bernstein and F. L. Hirshfeld at Jerusalem, which had 240 active participants and 50 accompanying members. There were no participants from Eastern Europe.

In Liège, a detailed report on ECM-8 was presented by L. Dupont and J. L. Toussaint, which had about 410 active participants and 40 accompanying participants. The scientific activity at ECM-8 was classified as 7 plenary lectures, 43 oral papers and 313 posters. The organizing committee had 15 members each with a specific responsibility.

2. At both the meetings, plans for future meetings were discussed. In Jerusalem, L. Dupont presented a report on the plans for the organization of ECM-8 in Liège. Similarly, G. Ferraris reported on plans for ECM-9 in Torino in 1985.

The Committee accepted the Polish Academy of Sciences' invitation to hold ECM-10 in Wroclaw in August 1986, subject to the condition that the Polish Government should guarantee visas for all those desiring to participate in the meeting.

G. Ferraris presented a progress report on ECM-9 at Liège. M. Nardelli was proposed as Chairman of the Programme Committee. Five main scientific topics are being planned for this meeting. They are: Fundamental crystallography, Crystallography and biology, Crystallography and chemistry, Crystallography and earth sciences, Crystallography and materials sciences. In addition, microsymposia or ad hoc meetings may also be organized.

ECM-10 (Wroclaw) was discussed in Liège where the Polish representative informed the committee that an official letter from the Polish Government was expected, assuring that visas will be guaranteed for all people desiring to participate, regardless of their country of origin. If such a letter was not received by 31 December 1983, the President would decide whether a new decision would be taken by the Committee.

The possibility of holding ECM-11 in Austria and ECM12 in the UK was discussed at both the meetings. In Liège, the Czechoslovakian representative informed the committee that he would investigate the possibility of hosting a meeting in his country in 1988 or 1989.

3. The cooperation scheme was discussed at both meetings. At the Jerusalem meeting the discussion on this item was centred upon how the crystallographers in the developing countries could be helped.
4. ECC financial matters came up for discussion in the Liège meeting where it was felt that, though the ECC does not have financial means, the present policy need not change. However, it was pointed out that the possibility of giving financial help to young crystallographers to attend ECM meetings should be pursued.

5. While discussing the item 'Officers for 1984-1987' in Liège, the principle of equal East and West participation in all aspects of European crystallography was taken into account.

6. In Jerusalem it was agreed that if an ECC representative or his alternative is not able to represent his country at a meeting, another active participant of his country may be asked to participate in the meeting.

7. In Liège the possibility of participation of other European countries in the ECC was discussed. It was agreed that several countries could, in principle, join the ECC, but there was no urgency in this. It was suggested that crystallographers living in countries which have no national organization in the field should be kept informed by the national committees of nearby countries.

18 June 1984. S. RAMASESHAN, Representative

Appendix F: Reports of the Representatives on bodies not belonging to the Union

(a) IUPAP Commission on the Structure and Dynamics of Condensed Matter

The change in the scientific direction of the Commission was approved by the General Assembly of the IUPAP and, ipso facto, the corresponding change of its name and composition. Formerly it was the Commission on the Solid State.

Each year the Commission studies the applications for conferences to be sponsored and supported by IUPAP, and makes appropriate recommendations. Recently, the scientific content of these conferences has differed to some extent from the conferences in the past, and their content was closer to the interests of crystallographers.

10 April 1984.

A. LÍNEK, Representative

(b) Conference Committee of the European Physical Society

The European Physical Society is a society with much activity in the field of conferences and similar meetings of physicists in Europe. Its Conference Committee meets once a year in different European cities. It is concerned that all meetings approved or sponsored by the EPS have a high scientific quality, with unrestricted participation of all scientists.

At its meetings, the Committee discussed various possibilities to help the organizers of the conferences.

The information about European physics meetings is passed on for inclusion in the Forthcoming Meetings section in Journal of Applied Crystallography.
10 April 1984.
A. LÍNEK, Representative

\section{(c) ICSU Abstracting Board}

Two matters have preoccupied the ICSU Abstracting Board during the triennium: its restructuring to meet the current needs of the users, producers and distributors of scientific and technical information; and its relation with ICSU. In recent years, the distinction between primary producers and secondary and tertiary services, once sharp, 
has tended to become blurred or even to disappear. At the General Assembly in 1980, therefore, the Board decided that its membership classifications (member countries, member unions, member [secondary] services) no longer reflected current needs, and set up a committee to consider revision of the purposes and structure of the Board. In parallel with this, the Board's Sub-Committee on Statutes and By-Laws was asked to prepare a thorough revision of the Statutes and By-Laws, eliminating as far as possible ambiguities, repetitions and obsolete provisions. Both committees reported to the regular triennial General Assembly of the Board held in May 1983 and, as a result of full discussion, it was decided to hold an Extraordinary General Assembly in June 1984 to consider and vote on a new set of Statutes and By-Laws that incorporated the recommendations of the committees. The draft proposes three major changes from the current Statutes:

(i) The name of the organization would become the International Council for Scientific and Technical Information (ICSTI).

(ii) There would be two Classes of Full Members, Class A consisting of bodies primarily concerned with the production and utilization of information, and Class B of bodies primarily concerned with the distribution of information. (The IUCr would fall into Class A.)

(iii) In each Class there would be three Categories of dues (on a basis similar to that of the five IUCr categories). On major financial matters the number of votes would depend on the dues Category; on other matters each Full Member would have one vote. The dues for Class B members would be about twice as great as those for Class $A$ in each Category.

In addition to the Full Members, there is provision for Associate Members (organizations) and Honorary Members (persons). Such members would have the right to participate in meetings of ICSTI, but would have no vote. Union and Country membership, as such, would disappear, but all existing members in these classes would automatically become members in Class $A$.

For several years, ICSU has been expressing dissatisfaction with the ICSU Abstracting Board, though the reasons for the dissatisfaction have never been made clear. This dissatisfaction was known to the Sub-Committes on Statutes and By-Laws, and fully discussed in various contexts by the Executive Committee. However, the Board saw no reason from its side to propose substantial changes in its relations with ICSU, and the draft Statutes described above would retain ICSU as the Sponsoring Body of ICSTI and as a Member in Class A. On the other hand, at the meeting of the General Committee of ICSU in Warsaw in September 1983 the following resolution was adopted:

[The General Committee] recommends to the 20th General Assembly that the status of the ICSU Abstracting Board as a Permanent Service of ICSU be terminated and further recommends that the appropriate modes of cooperation between the Abstracting Board and the ICSU family be determined after the Abstracting Board has established its new structure and objectives.

The resolution originally proposed was much harsher in tone, and the help given by the IUCr representative on the General Committee of ICSU (Professor A. Magnéli) in obtaining a more moderate wording is greatly appreciated by the Board. The Statutes of ICSU make no provision for the status of 'Permanent Service of ICSU', so the effect of the recommendation, if adopted at the ICSU General Assembly in 1984, is not clear. One of the difficulties experienced by the Board in this matter was the reluctance of ICSU to reply to correspondence. In 1984, under the new officers of ICSU, communications have improved, but the situation remains unresolved.
16 May 1984.
A. J. C. Wilson, Representative

\section{(d) ICSU Committee on Data for Science and Technology} (CODATA)

CODATA will have held two General Assemblies during the present triennium. The first in 1982 was held at Jachranka near Warsaw. It was a small meeting and much of the discussion focused on the changing role of CODATA. Originally founded to encourage the scientific Unions to take seriously the importance of accurate data measurements and of ensuring their accessibility, CODATA has gradually changed its focus toward the new technologies of numeric computer databases. A special conference on the future of CODATA held in 1983 recommended that it concentrate on:

(a) Computerized data management (standards for the structure of databases, management and manipulation techniques).

(b) Preparation of computer-searchable directories of data sources.

(c) Joint projects with the Unions.

(d) Projects in which CODATA can play a coordinating role.

(e) Pilot data projects.

These recommendations will be discussed at the XIV General Assembly in Jerusalem in June 1984. I shall be able to give a verbal report on that meeting at our General Assembly in Hamburg in August 1984.
14 February 1984.
I. D. BROWN, Representative

\section{(e) ICSU Committee on Science and Technology in Develop- ing Countries (COSTED)}

One of the main activities of COSTED is to provide funds to help participants from developing countries to attend summer schools and, indeed, scholarships were promised to the summer schools organized by the IUCr in Cairo, Brasilia, Kyoto and Erice. However, there have been extreme difficulties concerning the payment of these scholarships. Not only has the correspondence and the coordination been practically nil with the Union representative and the officers of the Union but also with the schools organizers themselves, creating very great difficulties for them. It is very strongly to be hoped that this situation will improve in the future.
14 May 1984.
A. AUthier, Representative

\section{(f) ICSU Committee on Space Research (COSPAR)}

The meeting of COSPAR in Ottawa in May 1982 included a very successful symposium on 'Materials Science in Space'. Both theoretical and experimental aspects have been discussed, indicating interesting subjects for future experimentation. Also in this meeting, the enormous technological effort for material research in space was clearly visible. Unfortunately, there are many aspects of the various space programmes which are strongly criticized by the scientific community. The major drawback is that the national space organizations mainly finance equipment and 
flight expenses but neglect to some degree the ground-based scientific investigations. The USA and the Federal Republic of Germany are exceptions among the western countries. For smaller countries in particular, this situation sometimes leads to very expensive experiments which are inadequately prepared from the scientific point of view.

In the framework of ESA-NASA collaboration, the first space laboratory flight took place in November 1983. The results, as far as they could be evaluated up to now, seem to bring a breakthrough for the crystallization of proteins and enzymes. Dr Littke was able to grow under microgravity $1.3 \mathrm{~mm}$ single crystals of lysozyme. Compared to earth growth for the same period, these crystals were $1000 \times$ larger in volume. For $\mathrm{C}$-galactosides, the volume was $27 \times$ larger under microgravity conditions. Apart from the practical importance, the strong increase of the rate of crystal growth of proteins under microgravity conditions is very interesting from the point of view of the growth mechanisms.

18 May 1984.

E. KALDIS, Representative

\section{(g) ICSU Committee on the Teaching of Science}

The committee met twice during this period. On behalf of the IUCr, H. Schenk attended the meeting held in Paris on 28-29 November 1981 and P. Krishna attended the one held in Malvern, UK, 26-27 March 1983. The Committee is planning a major World Education Conference, 8-15 August 1985, at Bangalore, India, entitled 'Science and Technology Education and Future Human Needs'. The conference is being organized by the Indian National Science Academy and several Unions under ICSU, including the IUCr, are to contribute to the event. The main aim of this conference is to identify the future needs of humanity and evolve a strategy for the development and planning of education in various branches of science that would enable society to fulfil these needs in the following broad areas: Health, Food and agriculture, Energy, Mineral resources, Industry and technology, Environment, Information technology and Ethics. All participating Unions have been asked to consider possible inputs they can make under any of the above headings.

The Committee on the Teaching of Science is also interested in promoting the training of technicians in developing countries to assist in the maintenance and use of costly scientific equipment. The IUCr Commissions on Crystallographic Teaching and Crystallographic Apparatus can usefully collaborate in this programme to train technicians for crystallographic equipment. The person to contact is Professor D. J. Waddington, Chairman, CTS Sub-Committee on Technician Training, Department of Chemistry, University of York, York YO1 5DD, UK.

14 April 1984. P. KRISHNA, Representative

\section{(h) ICSU Scientific Committee on Problems of the Environment (SCOPE)}

During the triennium the General Assembly of SCOPE met in Ottawa, 30 May-5 June 1982, and the Executive Committee held an open meeting in New Delhi in February 1984. The ongoing SCOPE projects were reviewed and the guidance given by the General Assembly for the coming years was formulated. The scientific work has involved activities terminated according to plan, as well as continuing projects and new projects under way. Among the terminating activities are projects on noise pollution, the nitrogen cycle and modelling of ground-water ecology. Extensive reports have been published. The continuing projects concern the biogeochemical cycles of carbon and sulfur. The interactions that interconnect the major biogeochemical cycles of carbon, nitrogen, sulfur and phosphorus are dealt with in a major report, SCOPE 21. Among other continuing projects are land transformation and studies of the interaction between climate and society, as well as of wetlands and the coastal zone.

Among the new projects which have just started or are proposed are environmental consequences of nuclear war, ecology of biological invasions, response of ecosystems to climate change, cycling of metals and acid precipitation. Besides the meetings mentioned above, the SCOPE activities are also demonstrated by a large number of meetings for specialists which are held in different countries.

The involvement of crystallographers in the SCOPE projects has so far been rather limited. The use of applied crystallography as a tool for the study of solids should be recognized. It is important that crystallographers who are in a position to do so make the possibilities of applied crystallography known to their colleagues engaged in SCOPE projects.

4 May $1984 . \quad$ P. KIERKEGAARD, Representative

\section{Appendix G: Summary of the activities of the Sub-committee on the Union Calendar}

This Sub-committee is a Sub-committee of the Executive Committee and therefore, according to Statute $8 \cdot 1$, has no obligation to report to the General Assembly. However, a summary of its activities is given in this Appendix for the information of delegates.

During the period since the Twelfth General Assembly, the Sub-committee has considered many requests for sponsorship and financial support by the Union, and has made recommendations accordingly to the Executive Committee. The following meetings and schools on topics of crystallographic significance have received Union sponsorship. Those which also received financial support from the Union are indicated by an asterisk. The list includes meetings which were awarded Union sponsorship by the Executive Committee before the Twelfth General Assembly. The Union also provided financial support for the Thirteenth International Congress of Crystallography.

*International School on Synthesis, Crystal Growth and Characterization of Materials for Energy Conversion and Storage, New Delhi, India, 12-23 October 1981.

Meeting on Neutron Scattering and Diffraction Techniques for Macromolecular Structure Determination, Brookhaven, USA, 31 May-4 June 1982.

*Workshop on the Crystallography of Molecular Biology, Erice, Italy, 7-19 June 1982.

Sagamore VII Conference on Charge, Spin and Momentum Densities, Nikko Kanaya Hotel, Japan, 25-30 August 1982.

Seventh European Crystallographic Meeting, Jerusalem, Israel, 29 August-3 September 1982. 
*International School on Materials Science and Solar Energy, Cairo and Alexandria, Egypt, $18 \mathrm{March}-1$ April 1983.

*International School on Teaching Crystallography for Materials Science, Brasilia, Brazil, 18-27 July 1983.

Eighth European Crystallographic Meeting, Liège, Belgium, 8-12 August 1983.

* International Summer School on Crystallographic Computing, Kyoto, Japan, 18-27 August 1983.

* Fifth International Summer School on Crystal Growth and Materials Science, Davos, Switzerland, 3-10 September 1983.

VII International Conference on Crystal Growth, Stuttgart, Federal Republic of Germany, 12-16 September 1983.

Fifth European Meeting on Ferroelectricity, Torremolinos, Spain, 26 September-1 October 1983.

International Course on Direct Methods of Solving Crystal Structures, Erice, Italy, 7-19 April 1984.

*Conference on Crystal Growth and Characterization of Polytype Structures, Marseille, France, 3-6 July 1984.

*International Summer School on Crystallographic Computing, Mulheim/Ruhr, Federal Republic of Germany, 30 July-8 August 1984.

*Symposium on Neutron Scattering, West Berlin, Federal Republic of Germany, 6-8 August 1984.

* Symposium on Small-Angle Scattering and Related Methods, Hamburg, Federal Republic of Germany, 2023 August 1984.

*Symposium on Metals and Intermetallic Compounds, Aachen, Federal Republic of Germany, 20-24 August 1984.

*International Summer School on Symmetry-Related Crystal Structures: Group-Subgroup Relations, Marburg, Federal Republic of Germany, 20-24 August 1984.

Sixth International Meeting on Ferroelectricity, Kobe, Japan, 12-16 August 1985.

Sagamore VIII, Sanga-Saby, Sweden, 28 July-3 August 1985.

A list of meetings of interest to crystallographers is published in each issue of the Journal of Applied Crystallography. Attempts to make this list as comprehensive as possible depend to a large extent on the Executive Secretary being informed of relevant meetings by National Committees and individual crystallographers.

Appendix H: Budget estimates for the period to the Fourteenth General Assembly: determination of the unit contribution

\section{(a) Budget estimates}

As previously, an estimated budget for the period until the next General Assembly has been prepared for the General Fund only. Since the budget estimates had to be prepared at a time when the decisions on many activities had still to be made, these estimates should be considered with due reserve. With this proviso, and in accordance with Statute $9 \cdot 3$, the Executive Committee presents to the Thirteenth General Assembly the following estimates for the three-year period 1 January 1984-31 December 1986.

\begin{tabular}{lr} 
Income & \multicolumn{1}{c}{ Sw Fr } \\
Subscriptions from Adhering Bodies & 389,820 \\
Yield from investments and banking & \\
accounts & 350,000 \\
Subventions from Unesco through ICSU & 75,000 \\
Sale of incidental publications & 22,000 \\
\cline { 2 - 2 } & \\
& \\
Expenditure & 351,400 \\
Administration & 12,000 \\
Subscriptions to ICSU and ICSU bodies & 144,000 \\
Administrative Meetings & 306,800 \\
Scientific Meetings & 22,000 \\
Cost of incidental publications &
\end{tabular}

836,820

51,400

2,000

306,800

22,000

Estimated profit

The income from subscriptions from Adhering Bodies has been determined on the basis of a unit contribution of Sw Fr 890 for 1984, 1985 and 1986. As in the past, the above budget assumes that part of the expenses of the administration (Sw Fr 150600) will be charged to the publication accounts. Thus the total expenses of administration are estimated at Sw Fr 502000.

Expenses included under 'Administrative Meetings' are those of the Executive Committee and Finance Committee meetings, Union representation on other bodies and the printing of the report of the General Assembly. The heading 'Scientific Meetings' includes financial support for scientific meetings organized or sponsored by the Union as well as the expenses of the non-publishing Commissions, the Commission Chairmen and the Scientific Programme Committee for the triennial Congresses of Crystallography. The expenses of the publishing Commissions are charged to the relevant publication.

The Executive Committee is conscious of the need to keep administrative expenses to a minimum. However, the Executive Committee is required to meet at least twice during the period between the General Assemblies (By-Law $2 \cdot 1$ ), and it is felt that these annual meetings and the meetings of the Finance Committee are necessary if effective control is to be maintained over the financial affairs of the Union, particularly with regard to the very large publishing activities.

\section{(b) Unit contribution}

According to Statute $5 \cdot 10(k)$ the General Assembly has to determine the unit contribution from the Adhering Bodies for the period to the next General Assembly.

The Executive Committee appreciates that some Adhering Bodies had experienced difficulties with the increase adopted by the last General Assembly. The Executive Committee was therefore against any further increase in the next triennium. It was decided that the unit contribution should continue to be expressed in Swiss Francs but should be equivalent to US $\$ 400$ at the time of preparing the Agenda papers. However, it should not be more than the present level of Sw Fr 890. The Treasurer was authorized to make the final decision. He proposes therefore that the unit contribution should be Sw Fr 890 for the years 1984, 1985 and 1986. (At the end of March 1984 this was equivalent to US \$397.) 


\section{ANNEX II}

\section{Statutes and By-Laws of the International Union of Crystallography}

as Adopted by the Fourth General Assembly in 1957 and Amended by the Fifth General Assembly in 1960, the Sixth General Assembly in 1963, the Seventh General Assembly in 1966, the Eighth General Assembly in 1969, the Ninth General Assembly in 1972, the Tenth General Assembly in 1975, and the Eleventh General Assembly in 1978

\section{Statutes}

\section{Objects of the Union}

1.1. The objects of the Union are

(a) to promote international cooperation in crystallography;

(b) to contribute to the advancement of crystallography in all its aspects, including related topics concerning the non-crystalline states;

(c) to facilitate international standardization of methods, of units, of nomenclature and of symbols used in crystallography;

(d) to form a focus for the relations of crystallography to other sciences.

1.2. For these purposes the Union shall have the power

(a) to adhere to the International Council of Scientific Unions;

(b) to organize international meetings and conferences on subjects falling within the purview of the Union;

(c) to promote international publication of crystallographic research and of crystallographic works;

(d) to set up Commissions or other bodies for special objects;

(e) to initiate, promote and coordinate crystallographic research requiring international cooperation;

$(f)$ to organize Special Projects which shall be financed independently of the regular operations of the Union;

(g) to participate in Joint Commissions with other Unions or other scientific bodies in matters of interest to the Union;

(h) to perform all such other legal acts as are essential for or conducive to the objects of the Union including the constitution or organization of separate or independent bodies having an appropriate legal status;

(i) to receive into association existing regional organizations of crystallographers having substantially the same aims and objects as the Union; these organizations shall be known as Regional Associates of the Union;

$(j)$ to receive into association existing international scientific organizations whose interests overlap with the aims and activities of the Union; these organizations shall be known as Scientific Associates of the Union.

\section{Organization and Legal Domicile}

2.1. Under the name of International Union of Crystallography an Association has been organized and incorporated; it is governed by Articles 60 and following of the Swiss Civil Code and by the present Statutes of Incorporation.
2.2. The duration of the Union is not limited.

2.3. The legal domicile of the Union is in Geneva, Switzerland.

\section{Membership}

3.1. The members of the Union are its Adhering Bodies.

$3 \cdot 2$. There shall be only one member for each Country.

3.3. In a Country the Adhering Body can be a National Academy, National Research Council or similar body, or a scientific society or group of such societies. Each Adhering Body shall form a National Committee for Crystallography to represent it in the Union.

3.4. Any number of Countries may agree to form a group in order to name or establish a single Adhering Body. This Body shall form a joint National or Regional Committee for Crystallography. Wherever the terms Country and National Committee for Crystallography are used in these Statutes or in the By-Laws, they shall be taken to include such groups of Countries and joint National or Regional Committees for Crystallography.

3.5. Membership in the Union shall be fully effective when the nature of the Adhering Body and the membership of the National Committee have been reported to and accepted by the General Assembly. Any replacement of an Adhering Body is subject to the approval of the Executive Committee and acceptance by the General Assembly. Any major change in the nature of an Adhering Body shall be considered valid only after it has been reported to and accepted by the General Assembly.

3.6. Adherence to the Union shall be in one of five Categories I-V with corresponding voting powers and contributions as set out in Statutes 5.5 and 9.4. A Body applying for adherence to the Union shall specify in which Category it wishes to adhere; this choice of Category, or any desired change in the Category, is subject to the approval of the Executive Committee and confirmation by the General Assembly.

3.7. Any extension of a joint adherence formed in accordance with Statute 3.4 is subject to the approval of the Executive Committee and acceptance by the General Assembly.

3.8. Participation in Special Projects [Statute 1.2( $f)$ ] shall not be obligatory. The extent of financial participation shall be a matter for special negotiation for each such project, except that the relationship between contribution and voting power within the project shall be that of the Category scheme defined in Statutes 5.5 and 9.4 to determine this relationship in the General Assembly. 
3.9. Each National Committee has the right to submit to the Union through the General Secretary questions within the competence of the Union.

3.10. Any Adhering Body may withdraw from the Union if it has given notice of withdrawal at least six months before the end of the current financial year; it is required to fulfil its obligations relating to the time period when it was a member of the Union. Its membership and any further obligations shall then be suspended by the Executive Committee at the expiry of the notice of withdrawal. The withdrawal shall take effect when it has been reported to the General Assembly.

3.11. An Adhering Body which withdraws from the Union in accordance with Statute $3 \cdot 10$, or any Adhering Body whose membership is cancelled in accordance with Statutes $5 \cdot 12$ or $9 \cdot 6$, loses all rights in connexion with the Union.

$3 \cdot 12$. If the Countries of a group formed in accordance with Statute 3.4 agree that the group should be dissolved, or if a Country wishes to withdraw from such a group, with or without the agreement of the other Country or Countries of the group, the adherence of the original group shall be suspended by the Executive Committee at the expiry of an appropriate notice, provided that the original group has fulfilled its obligations. The termination of the original adherence shall take effect when the matter has been reported to the General Assembly. Pending this report, the Countries of the group, or any of them, may submit proposals for the continuation of their representation in the Union. In each of such proposals the nature of the Adhering Body, the membership of the National Committee and the desired Category of adherence shall be specified. These proposals are subject to the approval of the Executive Committee, which shall then make ad interim arrangements concerning these adherences. These arrangements are subject to acceptance by the General Assembly.

\section{Administration}

4.1. The work of the Union shall be conducted by

(a) the General Assembly;

(b) the Officers of the Union, constituting the Executive Committee;

(c) the Commissions as defined in Statute $8 \cdot 1$.

The composition and function of these bodies are defined in the following paragraphs, whose application is governed by the By-Laws.

\section{General Assembly}

$5 \cdot 1$. The work of the Union shall be directed by the General Assembly which is composed of delegates appointed by the Adhering Bodies.

5.2. The Executive Committee is responsible to the General Assembly and shall participate in its deliberations. Members of the Executive Committee have no voting power in the General Assembly, except for the casting vote of the Chairman [Statute 5.8].

5.3. The General Assembly shall, as a rule, hold an ordinary meeting once every three years. The date and the place of the meeting, unless determined by the previous General Assembly, shall be determined by the Executive Committee. The General Secretary shall communicate the date and the place of the meeting to the National Commit- tees and to the Commissions at least twelve months in advance.

5.4. In special cases, the President of the Union, with the consent of the Executive Committee, may call an extraordinary meeting of the General Assembly. He shall do so at the request of one-fifth of the Adhering Bodies. The routine business of a General Assembly prescribed in Statute $5 \cdot 10$ shall normally be omitted, unless specifically included in the agenda; but an extraordinary General Assembly shall have the same powers, and be subject to the same rules, as an ordinary General Assembiy, except where otherwise is stated in the Statutes and By-Laws. The General Secretary shall communicate the date and the place of the extraordinary General Assembly to the National Committees and to the Commissions at least eight months in advance if amendment of the Statutes is contemplated, or at least four months otherwise.

5.5. The voting power of an Adhering Body at General Assemblies shall be in accordance with its Category of adherence, as follows

$\begin{array}{lccccc}\text { Category } & \text { I } & \text { II } & \text { III } & \text { IV } & \text { V } \\ \text { Number of votes } & 1 & 2 & 3 & 4 & 5 .\end{array}$

5.6. Each Adhering Body, through its National Committee, shall make known to the General Secretary before the opening of each General Assembly the names of its delegates (and of their alternates, if any), and also the name of the chairman of the national or regional delegation. No Officer of the Union may be a member of any delegation, nor shall any person serve as a member of more than one delegation.

5.7. Normally each of the delegates present at a General Assembly shall have one vote only, but when for special reasons an Adhering Body cannot be fully represented at a General Assembly it may distribute its votes among a number of delegates smaller than the number of votes which that Adhering Body has in accordance with the Category in which it adheres; such a decision has to be made known to the General Secretary before the opening of the General Assembly concerned. Any Adhering Body not represented at a General Assembly may forward its views to the General Secretary by letter, and such views shall be made known to the General Assembly if received before voting takes place.

5.8. Except where otherwise provided in the Statutes and By-Laws, decisions of the General Assembly are taken by a majority of the votes cast. In the event of an equal division of votes the Chairman shall take the final decision.

5.9. No question which has not been placed on the agenda of business to be transacted at the General Assembly shall be discussed or put to the vote unless a proposal to that effect be approved by at least two-thirds of the votes there represented.

5·10. The General Assembly shall

(a) take appropriate action on any matters concerning membership in the Union [Statutes $3 \cdot 5,3 \cdot 6,3 \cdot 7,3 \cdot 10$, $3 \cdot 12$ and $5 \cdot 12]$;

(b) elect the President, the Vice-President, the General Secretary, the Treasurer and the other Officers of the Union [Statutes 6.1 and 6.3];

(c) consider, and make decisions regarding, the confirmation of the appointments of Editors of publications of the Union [Statute $7 \cdot 1$ ]; 
(d) determine the number of elected members of each Commission set up by the General Assembly [Statutes $5 \cdot 11(c)$ and $8 \cdot 2]$

(e) elect the Chairmen and members of the Commissions [Statute 8.2];

( $f$ ) elect representatives of the Union on Joint Commissions with other Unions, and on other scientific bodies [Statutes $1 \cdot 2(\mathrm{~g})$ and $8 \cdot 5$ ];

(g) receive the reports on the activities of the Union and of its Commissions [Statutes 6.8 and 8.4 ];

(h) receive the audited accounts for the years elapsed since the previous General Assembly [Statute 9.1];

(i) on receipt of satisfactory reports or accounts, release the Treasurer, or any other Officer, or the Chairman or any member of any Commission or other body, from financial or other liability to the Union;

(j) determine the budget for general expenditure for the period to the next General Assembly, on the basis of the estimate prepared by the Executive Committee [Statutes $\mathbf{9 \cdot 2}$ and $9 \cdot 3$ ];

(k) determine the unit contribution for the period to the next General Assembly [Statute 9.5];

(l) determine the general policy and the timetable for the period to the next General Assembly;

$(m)$ give preliminary consideration to the activities of the Union for the three-year period following the next General Assembly.

5.11. The General Assembly shall have the power

(a) to amend these Statutes in accordance with Statute 13.1;

(b) to formulate and amend By-Laws on any matters not covered by these Statutes;

(c) to set up any Commission or other body it may deem necessary for the administrative and scientific work of the Union, and to determine the terms of reference of such a body [Statute $1 \cdot 2(d)$ ];

(d) to dissolve any Commission or other body set up in accordance with Statute $5 \cdot 11(c)$ when its existence is deemed no longer necessary;

(e) to determine the nature of Special Projects which shall be financed independently of the regular operations of the Union [Statute $1 \cdot 2(f)]$;

$(f)$ to accept Regional Associates, to determine the nature of the association in each case, and to determine any mutual financial commitments;

(g) to accept Scientific Associates, to determine the nature of the association in each case, and to determine any mutual financial commitments;

(h) to decide on all other questions falling within the competence of the Union.

5.12. The General Assembly may cancel the membership of any Adhering Body of the Union for any serious cause; such a decision may only be taken after the member in question has been previously given an opportunity to furnish an explanation to the Executive Committee for forwarding to the General Assembly. At least three-fourths of the total number of the votes of all Adhering Bodies are required for cancellation.

\section{Executive Committee}

6.1. The Officers of the Union constituting the Executive Committee are (a) the President;

(b) the Vice-President;

(c) the General Secretary;

(d) the Treasurer;

(e) the immediate Past President;

$(f)$ six ordinary members.

6.2. The election of Officers of the Union shall be arranged in such a way that there will not be more than two Officers from any one Country. A person is regarded as belonging to the Country in which he is normally resident and where he conducts the main part of his work. In cases of doubt the General Assembly shall decide to which Country a person is considered to belong.

If during the period between General Assemblies the number of Officers from a Country is increased above two because of any change of Country of residence, the Officer or Officers who changed his or their Country of residence may continue his or their service until the close of the next General Assembly. If at that time the number of Officers from the Country concerned would remain above two, one or more of the Officers who changed his or their Country of residence shall be considered to have resigned.

6.3. The offices of General Secretary and Treasurer may be combined and shall then be considered as a single office. Otherwise no person shall hold more than one office simultaneously. The voting power of the Officer holding the combined office of General Secretary and Treasurer shall not be more than that of either the General Secretary or the Treasurer.

6.4. The President holds office as President until the close of the ordinary General Assembly following his election, and continues as a member of the Executive Committee until the close of the ordinary General Assembly next but one following that of his election. He is not then eligible for immediate re-election to the office of President, nor to any other office in the Executive Committee.

The Vice-President holds office until the close of the ordinary General Assembly following his election. He is not eligible for immediate re-election to the same office.

The General Secretary and the Treasurer hold office until the close of the ordinary General Assembly following that of their election. They are eligible for immediate re-election to the same office, but shall not serve in that office for more than three full consecutive terms.

Three ordinary members are elected at each ordinary General Assembly and hold office until the close of the ordinary General Assembly next but one following that of their election. They are not eligible for immediate re-election to the same office.

In the event of a vacancy, through resignation, death or other cause, any Officer elected by the General Assembly to fill the unexpired term of office shall serve only to the end of the normal term of the Officer he replaces; at the end of this service he may be nominated for re-election for a full term to the same office.

6.5. The Executive Committee shall carry out the decisions of the General Assembly and give effect to the general policy of the Union as determined by the General Assembly.

6.6. During the periods between General Assemblies the Executive Committee shall have full power to carry on the business of the Union in all matters not specifically assigned by the Statutes, the By-Laws or the General Assembly to individuals or to Commissions or other bodies. If necessary, 
it may make ad interim arrangements in all matters assigned by the Statutes and By-Laws to the General Assembly.

6.7. In the event of an individual, a Commission or another body of the Union failing to act in any matter assigned to him or it by the Statutes, By-Laws or the General Assembly, the Executive Committee may, after reasonable notice to the individual or body in question, take action on behalf of the Union.

6.8. The Executive Committee shall report on its activities to the General Assembly. The action taken by the Executive Committee in accordance with Statutes $3 \cdot 5,3 \cdot 6$, $3 \cdot 7,3 \cdot 10,3 \cdot 12,6 \cdot 6,6 \cdot 7,7 \cdot 1,7 \cdot 2,8 \cdot 2,9 \cdot 6$ and $9 \cdot 9$ shall be included in this report. The report to the General Assembly shall be dispatched by the General Secretary to the National Committees and to the Commissions at least ten weeks before the meeting.

\section{Publications of the Union}

7.1. The Editors of the publications of the Union are appointed by the Executive Committee for initial terms extending through not more than six years beyond the ordinary General Assembly following the appointment. Each initial appointment is subject to confirmation by that General Assembly. Reappointments may be made by the Executive Committee for terms of not more than three years, and are subject to confirmation by the ordinary General Assembly following the reappointment.

7.2. Co-editors and Assistant Editors are appointed by the Editors for terms of not more than three years, but they may be reappointed immediately for terms of the same length. The appointments and reappointments are subject to the approval of the Executive Committee.

7.3. Editors and Co-editors are members of the Commissions set up for their respective publications.

\section{Commissions and Joint Commissions}

$8 \cdot 1$. The term 'Commission' shall be understood to include all Commissions, Committees, and other bodies of the Union with the exception of National Committees for Crystallography, and the Executive Committee and its subcommittees.

8.2. The Chairmen and members of the Commissions are elected at each General Assembly. Subject to the approval of the Executive Committee, Commissions may co-opt further members during the periods between General Assemblies, and may fill vacancies arising from resignation, death or other cause. Members (but not Chairmen) may be nationals of or residents in a Country not adhering to the Union.

8.3. The Commissions shall be responsible to the General Assembly. They shall generally have full freedom in arranging their internal structure and work. They may formulate their own Rules of Procedure within the framework of the Statutes and By-Laws of the Union, and within their terms of reference.

$8 \cdot 4$. The Chairmen shall report on the activities of the Commissions to the General Assembly. These reports shall reach the General Secretary at least fourteen weeks before the General Assembly and shall be dispatched by him to the National Committees and the Commissions at least ten weeks before the meeting.
8.5. The representatives of the Union on Joint Commissions and on other scientific bodies [Statute $1 \cdot 2(g)$ ] are elected at each General Assembly. For each such body one representative shall be designated as the chief representative of the Union. His obligations to report are the same as those of the Chairmen of the Commissions.

\section{Finance}

9.1. The Executive Committee shall be responsible to the General Assembly for all the financial affairs of the Union.

9.2. The Chairman of each Commission (or other member approved by the Executive Committee) shall be responsible to the Executive Committee for any expenditure of funds by his Commission. Five months before each General Assembly he shall submit to the Executive Committee an estimate of the budget of his Commission for the period between that General Assembly and the one following it. $\mathrm{He}$ shall submit annually to the Executive Committee a revised budget for the ensuing year and a statement of accounts for the preceding year. His accounts shall be available for audit by the Executive Committee or its appointees.

9.3. The Executive Committee shall prepare an estimate of the budget for the period between the next General Assembly and that following it. This estimate shall be dispatched by the General Secretary to the National Committees and to the Commissions at least ten weeks before the meeting.

9.4. Each Adhering Body shall pay an annual subscription in accordance with its Category of adherence, as follows:

$\begin{array}{lccccc}\text { Category } & \text { I } & \text { II } & \text { III } & \text { IV } & \text { V } \\ \text { Number of unit contributions } & 1 & 3 & 6 & 10 & 15 .\end{array}$

The annual subscriptions are payable during the calendar year to which they apply.

9.5. The unit contribution, stated in terms of a currency to be designated by the Executive Committee, shall be determined by the General Assembly for the period to the next General Assembly.

9.6. Any Adhering Body which is in arrears with its subscription for two years shall be warned and shall be deprived of its voting power. The membership of any Adhering Body which is in arrears for four years shall be automatically suspended and may be cancelled by the General Assembly under Statute 5.12. An Adhering Body whose membership has been suspended shall receive no privileges of the Union and incur no further responsibility for dues; it may be reinstated by action of the Executive Committee.

9.7. The financing and management of publications of the Union shall be kept distinct from general expenditure. Editors and Co-editors shall be responsible to the Executive Committee for any receipts or expenditure of funds by them with respect to their publications.

9.8. The financing and management of Special Projects of the Union shall be kept distinct from the regular operations of the Union.

9.9. No funds may be solicited or accepted on behalf of the Union or any of its Commissions from any international, governmental or other agency or person without the prior approval of the Executive Committee. Any National Committee for Crystallography may however solicit funds within 
its own Country for the support of its own activities or in its capacity as host for a General Assembly, Congress or other meeting sponsored by the Union. Any funds, in the form of donations, legacies, or grants, accepted by the Executive Committee shall be used so far as is possible in accordance with the wishes of the donors.

\section{Liability}

10.1. The Union is liable only to the extent of its assets, and the Adhering Bodies are not individually liable for its corporate debts and liabilities.

10.2. The liabilities of the Adhering Bodies are limited to the payment of their annual subscriptions and to such contributions to the Special Projects of the Union as they may have pledged.

10.3. No Officer of the Union shall be individually liable for the corporate debts and liabilities of the Union. The Union shall indemnify any Officer or former Officer in respect of any claims laid against him in respect to his authorized actions on behalf of the Union. At its discretion the Executive Committee may extend this indemnity to other persons in respect of their authorized actions on behalf of the Union.

10.4. The Union shall not accept any liability for any personal loss, damage or accident sustained by an individual, not being an employee of the Union, engaged in any activity, including travel, on behalf of the Union.

\section{Auditor and Representation of the Union}

11.1. The Auditor of the Union shall be a person or corporation authorized to act as a public accountant. The Auditor shall be appointed by the Executive Committee on the recommendation of the Treasurer and maintained thereafter subject to the approval of the General Assembly.

$11 \cdot 2$. With the exception of cheques, all contracts and formal agreements involving the Union shall be signed by two Officers of the Union. The Executive Committee may restrict the power to sign a particular document or type of document to specific persons among the Officers; and it shall determine rules for the signing of cheques.

11.3. The President shall be the official representative of the Union on all other civil and legal occasions and in dealing with other organizations. He may in this respect delegate his powers to another Officer of the Union, or, with approval of the Executive Committee, to any other person.

\section{Dissolution of the Union}

12-1. The Union shall not be dissolved except on a motion presented at a General Assembly. If a motion to dissolve is to be presented, the notice for that General Assembly as given under Statute 5.3 or 5.4 shall include a statement of the motion to dissolve and shall refer specifically to this Statute. Such a motion shall be presented to the General Assembly without amendment and at least three-fourths of the votes there represented shall be required for dissolution.

In the event that less than three-fourths of the total number of the votes of all Adhering Bodies are represented at the General Assembly, a postal ballot may be arranged, and in such a postal ballot at least three-fourths of the total number of the votes of all Adhering Bodies shall be required for dissolution.

$12 \cdot 2$. In the event of dissolution of the Union in accordance with Statute $12 \cdot 1$, the General Assembly shall appoint a special Committee, reporting to the International Council of Scientific Unions, for the liquidation of the assets of the Union. The net assets shall be given to one or more, preferably international, organizations or institutions which shall spend the assets for purposes so far as is possible in accordance with the objects of the Union.

\section{Statutes}

13.1. Amendments to the Statutes require action at a General Assembly. An amendment is adopted at such an Assembly only if (i) at least two-thirds of the votes represented at the General Assembly are affirmative and (ii) if these affirmative votes amount to more than half the total number of the votes of all Adhering Bodies. In the event that the vote on a proposed amendment satisfies condition (i) but not condition (ii), the Executive Committee may refer the proposed amendment to a postal ballot of the Adhering Bodies. If the proposed amendment then obtains affirmative votes amounting to more than half the total number of the votes of all Adhering Bodies, the amendment is adopted.

Proposals for amendments may be made by the Executive Committee or by any National Committee. Such proposals made by National Committees shall reach the General Secretary at least six months in advance of the General Assembly. The General Secretary shall dispatch these proposals, and those made by the Executive Committee, to the National Committees and to the Commissions at least four months before the meeting.

13.2. The present English text shall be considered the authoritative text in the interpretation of these Statutes. Where disputes arise concerning this interpretation, the matter shall be decided by the General Assembly, or, during the periods between General Assemblies, by a ruling of the President of the Union.

\section{By-Laws}

\section{Genfral Assembly}

1.1. The agenda of business to be transacted at a General Assembly shall be determined by the Executive Committee and shall be dispatched by the General Secretary to the
National Committees and to the Commissions at least ten weeks before the meeting.

$1 \cdot 2$. Any National Committee and any Commission the Union may propose business to be transacted at a General Assembly. Such proposals shall reach the General 
Secretary at least four months before the meeting, and shall be included in the agenda of the General Assembly.

1.3. The General Assembly may provisionally determine the date and the place of the next but one ordinary meeting of the General Assembly.

1.4. Chairmen of the National Committees and of the Commissions, and representatives of Regional Associates and Scientific Associates may attend the General Assembly and take part in the discussions but shall have no voting power. The President may invite representatives of scientific bodies, or individuals, to attend the General Assembly; such invited guests may take part in the discussions but shall have no voting power. Other interested persons may also attend the General Assembly but they shall not take part in the discussions, unless specifically invited or permitted to do so by the Chairman, and they shall have no voting power.

At the discretion of the Chairman any or all of the persons attending the General Assembly under this By-Law may be required to withdraw.

1.5. If a delegate to a General Assembly is absent from a session of the Assembly, his place may be taken by any of the alternates nominated to the Assembly under Statute 5.6 provided that the Secretary of the Assembly is notified before the beginning of the session of the name of the delegate and of the name of the alternate, either by the delegate or by the chairman of his delegation. In general no such substitution may take place during a session of the Assembly, but the Chairman of the Assembly may permit substitution to be made under special circumstances.

1.6. The names of the representatives of a Body whose application for adherence to the Union has been received and declared in good order by the Executive Committee under By-Law 2.9(a) shall be made known to the General Secretary as prescribed in Statute $5 \cdot 6$. These representatives shall be seated with the delegates of the Adhering Bodies during the preliminary ceremonies and the initial business of the General Assembly. At the discretion of the Chairman or by a vote of the Assembly, the representatives may be required to withdraw during the discussion of and voting on matters concerning adherence to the Union. The delegates of a new member may take their seats among the other delegates as soon as the General Assembly has accepted their Adhering Body as a member of the Union.

1.7. Unless decided otherwise by the General Assembly, matters concerning adherence to the Union shall take precedence over all other business at the first business session of the General Assembly, and shall normally precede the reading of the minutes and the discussions of matters arising therefrom.

1.8. Delegates of an Adhering Body may not vote on any matter concerning its membership in the Union.

1.9. In the event of the General Assembly considering a change in a group of Countries according to Statute $3 \cdot 12$, the delegates from the Countries belonging or previously belonging to the group may not vote on any matters concerning the representation in the Union of any of these Countries. After acceptance of the ad interim arrangements made by the Executive Committee under Statute $3 \cdot 12$, these delegates have full voting power.

1-10. The delegates of new members may not vote on any matters concerning adherence to the Union, nor on any matters concerning the adoption of the minutes of the previous General Assembly, during the General Assembly at which they themselves are admitted.

1.11. The General Secretary shall post on the official bulletin board of the General Assembly the names of the Chairmen and members (and alternates, if any) of the delegations and the numbers of votes represented by them.

1.12. During the General Assembly any delegate (or alternate) and any Officer of the Union is considered to have been notified of any action of the General Assembly, or of the Executive Committee, or of any Commission, if one of the two following procedures is adopted

(a) a notice is placed in the mail box or other location at which the delegate (or alternate) or the Officer is accustomed to receive his mail during the course of the General Assembly, or

(b) a notice is handed to the designated Chairman of each delegation with the specific request that he communicate its contents to his delegation, and to the General Secretary with the specific request that he communicate its contents to the Executive Committee,

provided that in either case a similar notice is posted on the official bulletin board.

1.13. Minutes of the meetings of the General Assembly shall be made. Copies of the draft minutes shall be communicated by the General Secretary to the National Committees, to the Officers of the Union and to the Chairmen of its Commissions. After approval at a subsequent General Assembly, two copies of the definitive minutes shall be signed by the Chairman and the Secretary of the session at which they are approved, and shall be kept by the President and the General Secretary.

\section{Executive Committee}

$2 \cdot 1$. The Executive Committee shall meet at each General Assembly. There shall be at least two additional meetings during the period between General Assemblies, unless the Executive Committee by a postal vote decides otherwise.

$2 \cdot 2$. The Executive Committee shall make nominations to the General Assembly for the Officers of the Union, for the Chairmen and members of the Commissions, and for representatives on Joint Commissions and on other scientific bodies. Normally these nominations shall be made after a preceding postal communication with the National Committees. In each case in which an Officer of the Union is nominated for another office, either by the Executive Committee or by delegates to the General Assembly [ByLaw 7.2], the Executive Committee shall also include a nomination for the office which would be vacated if the election to the other office occurs. If the election to the other office does not occur and if the Officer's term has not expired, the nomination to the office which would have been vacated shall not be considered.

$2 \cdot 3$. In the event of the resignation, death or disability of the President, the Vice-President shall assume the office of President until the close of the next ordinary General Assembly.

In the event of the resignation, death or disability of the Vice-President, the Executive Committee may appoint one of its members to serve as Vice-President until the close of the next ordinary General Assembly.

In the event of such circumstances that the General Secretary or the Treasurer cannot carry out his duties, the 
other shall assume those duties until the Executive Committee has considered the situation. In that event the Executive Committee may, but need not, appoint a new General Secretary or Treasurer to serve until the close of the next ordinary General Assembly.

In the event of the resignation, death or disability of an ordinary member of the Executive Committee, the Executive Committee may co-opt a new member to serve until the close of the next ordinary General Assembly.

The accession of an Officer of the Union to a new office under the conditions of this By-Law shall be accompanied by his resignation from the office to which he was previously elected, but service under this By-Law shall not affect his eligibility for immediate re-election to the new office.

2.4. Any Officer unable to attend a meeting of the Executive Committee may designate a deputy to attend that meeting. Such a deputy shall be named in writing to the President or the General Secretary. He shall have no voting power and shall not be counted as part of a quorum.

2.5. The President, on his own initiative or at the request of the Executive Committee, may invite any individual to be present at a meeting of the Executive Committee; such an invited guest may take part in the discussions but shall have no voting power.

2.6. At a meeting of the Executive Committee two-thirds (fractional parts neglected) of the Officers specified by Statutes $6 \cdot 1$ and $6 \cdot 3$, excluding any who have resigned or died, shall constitute a quorum; and decisions shall be taken by a simple majority of the Officers present and voting. The Chairman of the meeting shall not vote in open ballots; but in the event of an equal division of votes the Chairman may take the final decision. In secret ballots required by the Statutes or By-Laws or ordered by the Chairman he may vote at his discretion. If he does not vote and there is an equal division of votes he may take the final decision. If he has voted in a secret ballot he may not take the final decision, and must leave it to further discussion and ballot.

2.7. During the period between meetings of the Executive Committee, voting may take place by post. Adoption of a proposal shall require affirmative votes from two-thirds (fractional parts neglected) of the Officers specified by Statutes $6 \cdot 1$ and $6 \cdot 3$, excluding any who have resigned or died. No decision on any proposal other than calling or cancelling a meeting of the Executive Committee shall be made by postal vote in the event that at least two Officers express the wish that the matter concerned should first be given more or further consideration, either by correspondence or at a meeting of the Executive Committee.

2.8. Minutes of the meetings of the Executive Committee shall be made. Two copies of the minutes shall be signed by the Chairman and the Secretary of the meeting at which they are approved, and shall be kept by the President and the General Secretary. A summary of the draft minutes of meetings of the Executive Committee shall be despatched by the General Secretary to the National Committees within ten weeks of the conclusion of each meeting.

2.9. In addition to the obligations described in the Statutes and elsewhere in these By-Laws, the Executive Committee shall

(a) receive and report on applications for adherence to the Union if the nature of the applying Body and the membership of the National Committee have been duly reported to and considered to be in good order by the Executive Committee; pending the next General
Assembly the Executive Committee may in the case of such applications provide such services of the Union as it deems proper;

(b) consider and report on any other questions concerning adherence to the Union;

(c) present an annual report, including an audited statement of receipts and expenditure, to the National Committees;

(d) report to the Commercial Registry of Geneva any changes in the registered information concerning the Union;

(e) have the power to appoint representatives on scientific bodies not belonging to the Union.

\section{President}

3.1. The President of the Union is Chairman of the General Assembly and of the Executive Committee. In the absence of the President from a session or meeting, the Vice-President, or if he is not present another Officer of the Union designated by the Executive Committee, shall act as Chairman.

3-2. The President of the Union is an ex officio member, with voting power, of all Commissions of the Union.

\section{General Secretary}

4-1. The General Secretary of the Union is Secretary of the General Assembly and of the Executive Committee. In his absence from a session or meeting, another Officer of the Union designated by the Executive Committee shall act as Secretary.

4.2. The General Secretary of the Union is an ex officio member, with voting power, of all Commissions of the Union.

4.3. The General Secretary is responsible for conducting the ordinary business of the Union, with the exception of the financial administration, and for keeping its records.

\section{Treasurer}

5.1. The Treasurer of the Union is responsible for the financial administration of the Union and for keeping its accounts.

5.2. The Treasurer is an ex officio member of all Commissions of the Union, with voting power only for those questions which may involve the Union in financial commitments.

\section{Commissions of the Union}

6.1. The Chairmen of the Commissions and the chief representatives on Joint Commissions or other bodies shall forward records of all meetings of the Commissions to the President and the General Secretary. They shall report annually on the activities of these bodies to the Executive Committee.

$6 \cdot 2$. If funds are provided for the use of a Commission, it may make its own financial arrangements, with the prior approval of the Executive Committee and subject to the provisions of the Statutes and By-Laws. In cases where the Executive Committee has given prior approval, payments toward travelling expenses of Chairmen and members of 
Commissions may be made from the general funds of the Union.

6.3. No person who has served for three consecutive full terms of office on a Commission is eligible for nomination for a fourth consecutive term of service on the same Commission except as Chairman. In no case is any person eligible for more than four consecutive full terms of service on the same Commission. These limitations do not apply to Editors [Statute 7-1], Co-editors [Statute 7-2] and ex officio members. Any Commission, in its Rules of Procedure, may reduce the length of service specified here.

6.4 . In the event of the resignation, death or disability of the Chairman of any Commission, the Executive Committee shall appoint a member of that Commission to serve as Chairman until the close of the General Assembly following this appointment.

\section{Nominations and Elections}

7-1. All delegates (and alternates) shall be notified of the nominations presented by the Executive Committee under By-Law $2 \cdot 2$ for the Officers of the Union as early as possible and at least ninety-six hours before the scheduled commencement of the session of the General Assembly at which the vote is to be taken.

7.2. After the delegates have been notified of the nominations by the Executive Committee as prescribed in By-Law $7 \cdot 1$, other nominations for Officers of the Union may be made by any six or more delegates. Such nominations shall be made in writing to the General Secretary not less than thirty-six hours before the voting session and shall be accompanied by a written statement that the consent of the nominees has been obtained. These nominations shall be posted by the General Secretary on the official bulletin board not less than twenty-four hours before that session.

7-3. Recommendations from each Commission for the Chairman and members of the Commission shall be made in writing to the General Secretary not less than seventy-two hours before the voting session of the General Assembly. These recommendations shall be approved by a majority of the members of the Commission and shall be accompanied by a written statement that the consent of the persons recommended has been obtained. All delegates (and alternates) shall be notified of the nominations presented by the Executive Committee under By-Law $2 \cdot 2$ for the Chairman and members of each Commission at least forty-eight hours before the voting session.

7.4. After the delegates have been notified of the nominations by the Executive Committee as prescribed in By-Law $7 \cdot 3$, other nominations for the Chairman and members of each Commission may be made by any six or more delegates. Such nominations shall be made in writing to the General Secretary not less than twenty-four hours before the voting session and shall be accompanied by a written statement that the consent of the nominees has been obtained. These nominations shall be posted by the General Secretary on the official bulletin board not less than twelve hours before that session.

7.5. In voting for the President, Vice-President, General Secretary and Treasurer of the Union, each of these offices shall be taken separately and voting shall be by secret ballot. A simple majority of the votes represented by the delegates present at the voting session shall be required for election.
If there is only one candidate for one of these offices, his nomination shall be presented to the General Assembly and the candidate concerned shall be considered as elected. If there are two candidates or more, and an election is not achieved after two ballots, the candidate receiving the smallest number of votes in the second ballot shall be removed from the list. If an election is not achieved after $\left.\right|_{a}$ third ballot, this procedure shall be repeated until an election is achieved. Any ballot form showing more than one mark shall be invalid. Any contingency arising during the balloting shall be resolved by a ruling of the Chairman of the General Assembly.

7.6. The election of the ordinary members of the Executive Committee shall be by secret ballot, the ballot form showing the nominations presented by the Executive Committee and the nominations made by delegates. A simple majority of the votes represented by delegates present at the voting session shall be required for election. If there are not more candidates than vacancies, the nominations shall be presented to the General Assembly and the candidates shall be considered as elected. If there are more candidates than vacancies and all vacancies are not filled by election at the first ballot, a second ballot shall be arranged containing the names of the candidates not elected. If there are vacancies after the second ballot, the balloting procedure shall be repeated until all vacancies are filled; for each of these subsequent ballots the name of the candidate receiving the smallest number of votes on the preceding ballot shall be removed from the list. Any ballot form showing more marks than the appropriate number of vacancies shall be invalid. Any contingency arising during the balloting shall be resolved by a ruling of the Chairman of the General Assembly.

7.7. In the event that an election must be held to fill the unexpired term of an office vacated by an ordinary member [Statute 6.4], the nominations for this office shall be distinct from the nominations for ordinary members for full terms. A person may be nominated for both categories, but can be elected to only one office [Statute 6.3]. If ballots are required in the elections for both categories, the ballots for the full-term offices shall take place first. A person who has been elected to two consecutive non-full terms is not eligible, on completion of his second term, for immediate re-election as an ordinary member of the Executive Committee.

7.8. In voting for the Chairmen and members of the Commissions each Commission shall be considered separately. For the election of the Chairmen the procedure described in By-Law 7.5 shall be followed. For the election of the members of the Commissions the procedure described in By-Law 7.6 shall be followed except that no more than two ballots shall be held. Any vacancies still remaining may be filled as provided in Statute $\mathbf{8 \cdot 2}$.

7.9. The procedure for the nomination and election of representatives of the Union on Joint Commissions and on other scientific bodies is so far as is possible the same as that for the nomination and election of the Chairmen and members of the Commissions.

\section{By-Laws}

$8 \cdot 1$. These By-Laws may be amended or suspended at any General Assembly and at least two-thirds of the votes 
there represented are required for an amendment or suspension. A motion to amend or suspend, if not already included in the agenda of business of the General Assembly, may be placed there by the procedure of Statute $5 \cdot 9$. No notice is required for a proposal to suspend the time limits prescribed by By-Laws $7 \cdot 2$ and $7 \cdot 4$. Notification of any other motion to amend or suspend the By-Laws must be given by its originators to all delegates (and alternates) and to all Officers of the Union in accordance with the procedure prescribed in By-Law 1.12, at least forty-eight hours before the session of the General Assembly at which the motion is to be considered.

$8 \cdot 2$. Words importing the male sex in the Statutes and By-Laws shall include the female sex.

8.3. The present English text shall be considered the authoritative text in the interpretation of these By-Laws. Where disputes arise concerning this interpretation, the matter shall be decided by the General Assembly, or during the periods between General Assemblies, by a ruling of the President of the Union. 


\section{APPENDIX}

Timetable in Preparation for General Assembly

Statute By-Law

12 months Notice of date and place of ordinary General Assembly to National Committees and Commissions

8 months Notice of date and place of extraordinary General Assembly to National Committees and Commissions, if amendment of Statutes is contemplated

6 months

5 months

4 months

4 months

Proposals for amendments to Statutes to General Secretary

Estimated budgets from Commissions to Executive Committee

Proposals for agenda of General Assembly to General Secretary

Notice of date and place of extraordinary General Assembly to National Committees and Commissions, if amendment of Statutes is not contemplated

4 months

14 weeks

10 weeks

10 weeks

10 weeks

10 weeks

'Before'

Proposals for amendments to Statutes to National Committees and Commissions

Reports of Commissions to General Secretary

Report of Executive Committee to National Committees and Commissions

Reports of Commissions to National Committees and Commissions

Budget to National Committees and Commissions

Agenda to National Committees and Commissions

Timetable during General Assembly

96 hours

72 hours

48 hours

48 hours

36 hours

24 hours

24 hours

12 hours

Notice by National Committees to General Secretary of names of delegates, alternates and chairmen of delegations, and of distribution of votes if not one per delegate

Nominations by Executive Committee for Officers of Union

Recommendations by Commissions to General Secretary for Chairmen and members of Commissions

Nominations by Executive Committee for Chairmen and members of Commissions

Notification of motion to amend or suspend By-Laws

Notice to General Secretary of nominations by delegates for Officers of Union

Posting of nominations by delegates for Officers of Union

Notice to General Secretary of nominations by delegates for Chairmen and members of Commissions

Posting of nominations by delegates for Chairmen and members of Commissions

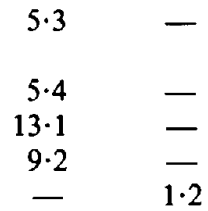

$5 \cdot 4$

$13 \cdot 1$

$8 \cdot 4$

$6 \cdot 8$

$8 \cdot 4$

$9 \cdot 3$

-

$1 \cdot 1$ 
ANNEX III

\section{Committees, Commissions, Regional and Scientific Associates and Representatives on Bodies not belonging to the Union}

\section{Membership of Bodies belonging to the Union}

\author{
EXECUTIVE COMMITTEE \\ President \\ Th. Hahn* \\ Inst. f. Kristallographie, \\ RWTH, Templergraben 55, \\ D-5100 Aachen, \\ Federal Republic of Germany
}

Vice-President

$$
\text { V. I. Simonov* (USSR) }
$$

General Secretary and Treasurer

K. V. J. Kurki-Suonio* Department of Physics, University of Helsinki, Siltavuorenpenger $20 \mathrm{D}$, SF-00170 Helsinki 17, Finland

\section{Immediate Past President \\ J. Karle* (USA)}

\section{Ordinary Members}

A. Authier $\dagger$ (France)

R. Diamond* (UK)

A. Kálmán† (Hungary)

E. N. Maslen† (Australia)

M. Nardelli* (Italy)

Y.-q. Tang* (People's Republic of China)

\section{Executive Secretary}

\section{J. N. King}

International Union of Crystallography, 5 Abbey Square, Chester CH1 2HU, England

COMMISSION ON JOURNALS

Chairman and Editor of Acta

Crystallographica

S. C. Abrahams

MH 6C-320, AT\&T Bell Laboratories, 600 Mountain Avenue, Murray Hill, New Jersey 07974, USA

* Until the close of the Fourteenth General Assembly (1987).

$\dagger$ Until the close of the Fifteenth Assembly (1990).
Co-Chairman and Editor of Journal of Applied Crystallography

M. Schlenker

Laboratoire Louis Néel du

CNRS, BP 166, F-38042

Grenoble Cedex, France

\section{Co-editors}

N. W. Alcock (UK; Acta) (as from December 1984)

C. E. Bugg (USA; Acta)

H. Burzlaff (Federal Republic of Germany; Acta)

R. Colella (USA; Acta)

J. Drenth (Netherlands; Acta)

A. Durif (France; Acta) (as from February 1986)

A. M. Glazer (UK; JAC) (as from January 1985)

T. A. Hamor (UK; Acta)

H. Hope (USA; Acta)

M. Hospital (France; Acta)

M. B. Hursthouse (UK; Acta) (as from January 1985)

H. Iwasaki (Japan; JAC) (as from January 1985)

G. Kostorz (Switzerland; JAC)

B. Morosin (USA; JAC) (as from February 1986)

M. Nardelli (Italy; Acta)

C. E. Nordman (USA; Acta)

R. Norrestam (Denmark; Acta)

E. Prince (USA; JAC) (as from February 1986)

S. E. Rasmussen (Denmark; $J A C)$

Y. Saito (Japan; Acta)

V. I. Simonov (USSR; Acta)

H. Steinfink (USA; Acta)

J. Trotter (Canada; Acta)

G. Will (Federal Republic of Germany; $J A C$ ) (as from April 1985)

B. T. M. Willis (UK; Acta)

\section{Book Review Editor}

J. H. Robertson (UK; Acta and JAC)
COMMISSION ON STRUCTURE

REPORTS

Chairman and Editor

G. Ferguson

Department of Chemistry, University of Guelph, Guelph, Ontario, Canada N1G 2W1

Co-editors

L. D. Calvert (Australia)

J. Iball (UK)

S. N. Scrimgeour (UK)

C. B. Shoemaker (USA)

J. Trotter (Canada)

\section{Ex officio member}

G. Bergerhoff (Federal Republic of Germany) (as Chairman of the Commission on Crystallographic Data)

\section{COMMISSION ON INTERNATIONAL} TABLES

Chairman and Editor

A. J. C. Wilson Crystallographic Data Centre, University Chemical Laboratory, Lensfield Road, Cambridge CB2 1EW, England

Co-editor

U. Shmueli (Israel)

Ex officio members

P. J. Brown (France) (as Chairman of the Commission on Charge, Spin and Momentum Densities)

D. C. Creagh (Australia) (as Chairman of the Commission on Crystallographic Apparatus)

K. Huml (Czechoslovakia) (as Chairman of the Commission on Crystallographic Computing)

C. J. Humphreys (UK) (as Chairman of the Commission on Electron Diffraction)

H. Schenk (Netherlands) (as Chairman of the Commission on Crystallographic Teaching)

B. T. M. Willis (UK) (as Chairman of the Commission on Neutron Diffraction) 
COMMISSION ON BIOLOGICAL

MACROMOLECULES

Chairman

C. I. Brändén

Department of Chemistry,

Div. 1, Agricultural College,

S-750 07 Uppsala 7, Sweden

\section{Elected members}

T. L. Blundell (UK)

S. Borisov (USSR)

P. M. Colman (Australia)

G. Dodson (UK)

W. A. Hendrickson (USA)

B. W. Matthews (USA)

D. Moras (France)

T. Tsukihara (Japan)

COMMISSION ON CHARGE, SPIN AND MOMENTUM DENSITIES

\section{Chairman}

P. J. Brown

Institut Laue-Langevin, Avenue des Martyrs, 156X Centre de Tri, 38042 Grenoble Cedex, France

\section{Elected members}

P. Becker (France) (Secretary)

S. Berko (USA)

J.-X. Boucherle (France)

D. E. Ellis (USA)

F. L. Hirshfeld (Israel)

F. Menzinger (Italy)

R. P. Ozerov (USSR)

J. R. Schneider (Federal Republic of Germany)

W. Shulke (Federal Republic of Germany)

E. D. Stevens (USA)

S. Wakoh (Japan)

\section{Ex officio member}

B. T. M. Willis (UK) (as Chairman of the Commission on Neutron Diffraction)

COMMISSION ON CRYSTAL GROWTH AND CHARACTERIZATION OF MATERIALS

\section{Chairman}

C. Paorici

Istituto MASPEC/CNR, Via Chiavari 18/A, 43100 Parma, Italy
Elected members

J. Barthel (German

Democratic Republic)

A. N. Christensen (Denmark)

H. C. Gatos (USA)

P. Hartman (Netherlands)

H. Komatsu (Japan)

A. R. Lang (UK)

S. O. Rundqvist (Sweden)

B. P. Sobolev (USSR)

\section{Ex officio members}

D. T. J. Hurle (UK) (as Representative of the International Organization for Crystal Growth)

M. Schlenker (France) (as Editor of Journal of Applied Crystallography)

COMMISSION ON CRYSTALLOGRAPHIC APPARATUS

\section{Chairman}

D. C. Creagh

Department of Physics, University College, University of New South Wales, Australian Defence Force Academy, Campbell, ACT 2600, Australia

\section{Elected members}

J. Čermák (Czechoslovakia)

R. Fourme (France)

H. Hashizume (Japan)

P. Kierkegaard (Sweden)

S. Martinez Carrera (Spain)

M. Materlik (Federal Republic of Germany)

\section{COMMISSION ON CRYSTALLOGRAPHIC} COMPUTING

Chairman

K. Huml

Institute of Macromolecular Crystallography, CSAV, Heyrovského nám 2, 16206 Praha 6, Czechoslovakia

\section{Elected members}

V. I. Andrianov (USSR)

H. Flack (Switzerland)

W. A. Hendrickson (USA)

N. Isaacs (Australia)

J. Rollett (UK)

H. Schenk (Netherlands)

D. Viterbo (Italy)

G. Bergerhoff (Federal Republic of Germany)
COMMISSION ON CRYSTALLOGRAPHIC DATA

Chairman

G. Bergerhoff

Anorganisch-chemisches

Institut der Universität Bonn,

Gerhard-Domagk-Str. 1,

D-5300 Bonn, Federal

Republic of Germany

\section{Elected members}

F. H. Allen (UK)

W. Jeitschko (Federal Republic of Germany)

T. Koetzle (USA)

K. Lukaszewicz (Poland)

P. Murray-Rust (UK)

K. Osaki (Japan)

Yu. Pushcharovski (USSR)

P. E. Werner (Sweden)

\section{Ex officio members}

S. C. Abrahams (USA) (as Chairman of the Commission on Journals)

G. Ferguson (Canada) (as Chairman of the Commission on Structure Reports)

K. Huml (Czechoslovakia) (as Chairman of the Commission on Crystallographic Computing)

COMMISSION ON CRYSTALLOGRAPHIC NOMENCLATURE

Chairman (ex officio as

Chairman of the Commission on Journals)

S. C. Abrahams MH 6C-320, AT\&T Bell Laboratories, 600 Mountain Avenue, Murray Hill, New Jersey 07974, USA

Ex officio members

G. Ferguson (Canada) (as Chairman of the Commission on Structure Reports)

M. Schlenker (France) (as Co-chairman of the Commission on Journals)

A. J. C. Wilson (UK) (as Chairman of the Commission on International Tables)

U. Shmueli (Israel) (as Editor of Volume B of Intermational Tables) 
COMMISSION ON CRYSTALLOGRAPHIC STUDIES AT CONTROLLED PRESSURES AND TEMPERATURES

Chairman

G. J. Piermarini

National Measurement

Laboratory, Center for

Materials Science, National

Bureau of Standards,

Washington, DC 20234, USA

Elected members

B. Buras (Denmark)

L. W. Finger (USA)

J. Ihringer (Federal Republic of Germany)

H. Iwasaki (Japan)

H. H. Schulz (Federal Republic of Germany)
A. K. Singh (India)
S. M. Stishow (USSR)
C. Vettier (France)

Ex officio members

D. C. Creagh (Australia) (as Chairman of the Commission on Crystallographic Apparatus)

C. J. Humphreys (UK) (as Chairman of the Commission on Electron Diffraction)

B. T. M. Willis (UK) (as Chairman of the Commission on Neutron Diffraction)

COMMISSION ON CRYSTALLOGRAPHIC

TEACHING

Chairman

H. Schenk

Department of Chemistry, University of Amsterdam, Nieuwe Achtergracht 166, 1018 WV Amsterdam, The Netherlands

\section{Elected members}

L. S. Dent Glasser (UK)

J. P. Glusker (USA) (Secretary)

E. Höhne (German Democratic Republic)

C. H. L. Kennard (Australia)

J. Lima-de-Faria (Portugal)

H. von Philipsborn (Federal Republic of Germany)

E. A. Pobedimskaya (USSR)

R. Srinivasan (India)

\section{COMMISSION ON ELECTRON} DIFFRACTION

\section{Chairman}

C. J. Humphreys

Department of Materials

Science and Engineering,

University of Liverpool,

PO Box 147,

Liverpool L69 3BX, England

\section{Elected members}

S. Amelinckx (Belgium)

C. Colliex (France)

J. M. Cowley (USA)

I. Hargittai (Hungary)

R. L. Hilderbrandt (USA)

P. Marcus (USA)

H. Oberhammer (Federal

Republic of Germany)

M. Prutton (UK)

M. Tanaka (Japan)

B. B. Zvyagin (USSR)

\section{COMMISSION ON NEUTRON}

DIFFRACTION

Chairman

B. T. M. Willis

Chemical Crystallography

Laboratory, 9 Parks Road,

Oxford OX1 3PD, England
Elected members

R. Chidambaram (India)

A. Delapalme (France)

G. Dolling (Canada)

T. Hicks (UK)

G. Lander (USA)

M. S. Lehmann (France)

I. Olovsson (Sweden)

W. Prandl (Federal Republic of Germany)

H. G. Smith (USA)

COMMISSION ON SMALL MOLECULES

Chairman

J. J. Stezowski Institut für Organische Chemie, Biochemie und Isotopenforschung der Universität Stuttgart, Pfaffenwaldring 55, D-7000 Stuttgart 80, Federal Republic of Germany

Elected members

P. W. Codding (Canada)

C. J. De Ranter (Belgium)

W. L. Duax (USA)

S. García Blanco (Spain)

M. Hospital (France)

A. Kálmán (Hungary)

S. Neidle (UK)

B. J. Oleksyn (Poland)

G. N. Tischenko (USSR)

M. Vijayan (India)

\section{Regional and Scientific Associates}

Regional Associate: EUROPEAN CRYSTALLOGRAPHIC COMMITTEE

Scientific Associate: INTERNATIONAL ORGANIZATION FOR CRYSTAL GROWTH

\section{Representatives on Bodies not bejlonging to the Union}

COMMISSION ON THE STRUCTURE AND DYNAMICS OF CONDENSED MATTER OF THE INTERNATIONAL UNION OF PURE AND APPLIED PHYSICS

\section{Representative}

M. Nardelli

Istituto di Chimica Generale ed Inorganica, Università di Parma, Viale delle Scienze, 43100 Parma, Italy
CONFERENCE COMMITTEE OF THE EUROPEAN PHYSICAL SOCIETY

\section{Representative}

M. Nardelli

Istituto di Chimica Generale ed Inorganica, Università di Parma, Viale delle Scienze, 43100 Parma, Italy
EUROPEAN CRYSTALLOGRAPHIC COMMITTEE

Representative

M. Nardelli

Istituto di Chimica Generale ed Inorganica, Università di Parma, Viale delle Scienze, 43100 Parma, Italy 
INTERNATIONAL ORGANIZATION FOR CRYSTAL GROWTH

Representative

C. Paorici

Istituto MASPEC/CNR,

Via Chiavari 18/A,

43100 Parma, Italy

INTERNATIONAL COUNCIL FOR SCIENTIFIC AND TECHNICAL

INFORMATION (FORMERLY ICSU ABSTRACTING BOARD)

Representative

A. J. C. Wilson

Crystallographic Data Centre, University Chemical Laboratory, Lensfield Road, Cambridge CB2 1EW, England

ICSU COMMITTEE ON DATA FOR SCIENCE AND TECHNOLOGY (CODATA)

Representative

G. Bergerhoff (Federal

Republic of Germany) ( $e x$ officio as Chairman of the Commission on Crystallographic Data)
ICSU COMMITTEE ON SCIENCE AND TECHNOLOGY IN DEVELOPING COUNTRIES (COSTED)

Representative

\section{J. Karle}

Code 6030, Laboratory for the Structure of Matter, Naval Research Laboratory, Washington, DC 20375, USA

ICSU COMMITTEE ON SPACE RESEARCH (COSPAR)

Representative

E. Kaldis

Laboratorium für Festkör-

perphysik, ETH-Hönggerberg, CH-8093 Zürich, Switzerland

ICSU COMMITTEE ON THE TEACHING OF SCIENCE

Representative

H. Schenk (Netherlands) ( $e x$ officio as Chairman of the Commission on Crystallographic Teaching)
INTERDIVISIONAL COMMITTEE ON NOMENCLATURE AND SYMBOLS OF THE INTERNATIONAL UNION OF PURE AND APPLIED CHEMISTRY

Representative

S. C. Abrahams (USA) (ex officio as Chairman of the Commission on Crystallographic Nomenclature) 


\section{ANNEX IV \\ Adhering Bodies}

\begin{tabular}{|c|c|c|}
\hline Country & Category* & Adhering Body \\
\hline Argentina & I & $\begin{array}{l}\text { Consejo Nacional de } \\
\text { Investigaciones Científicas y } \\
\text { Técnicas }\end{array}$ \\
\hline Australia & III & Australian Academy of Science \\
\hline Austria & I & $\begin{array}{l}\text { Österreichische Akademie der } \\
\text { Wissenschaften }\end{array}$ \\
\hline Belgium & II & $\begin{array}{l}\text { Académie Royale des Sciences, } \\
\text { des Lettres et des Beaux-Arts } \\
\text { de Belgique }\end{array}$ \\
\hline Brazil & III & $\begin{array}{l}\text { Conselho Nacional de } \\
\text { Desenvolvimento Cientifico e } \\
\text { Tecnologico }\end{array}$ \\
\hline Canada & III & National Research Council \\
\hline Chile & I & $\begin{array}{l}\text { Comision Nacional de } \\
\text { Investigacion Cientifica y } \\
\text { Tecnologia }\end{array}$ \\
\hline $\begin{array}{l}\text { China, People's } \\
\text { Republic of }\end{array}$ & IV & Academia Sinica \\
\hline Czechoslovakia & 1 & Československá Akademie Věd \\
\hline Denmark & I & $\begin{array}{l}\text { Royal Danish Academy of } \\
\text { Sciences and Letters }\end{array}$ \\
\hline $\begin{array}{l}\text { Egypt, Arab } \\
\text { Republic of }\end{array}$ & $\mathbf{I}$ & $\begin{array}{l}\text { Academy of Scientific Research } \\
\text { and Technology }\end{array}$ \\
\hline Finland & I & $\begin{array}{l}\text { Suomen Tiedeakatemiain } \\
\text { Valtuuskunta }\end{array}$ \\
\hline France & IV & $\begin{array}{l}\text { Académie des Sciences (Institut } \\
\text { de France) }\end{array}$ \\
\hline $\begin{array}{l}\text { German } \\
\text { Democratic } \\
\text { Republic }\end{array}$ & I & $\begin{array}{l}\text { Vereinigung für Kristallographie } \\
\text { in der GGW der DDR }\end{array}$ \\
\hline $\begin{array}{l}\text { Germany, } \\
\text { Federal } \\
\text { Republic of }\end{array}$ & IV & $\begin{array}{l}\text { Arbeitsgemeinschaft } \\
\text { Kristallographie }\end{array}$ \\
\hline Hungary & I & Magyar Tudományos Akadémia \\
\hline India & II & $\begin{array}{l}\text { Indian National Science } \\
\text { Academy }\end{array}$ \\
\hline Israel & I & $\begin{array}{l}\text { Israel Academy of Sciences and } \\
\text { Humanities }\end{array}$ \\
\hline Italy & III & $\begin{array}{l}\text { Consiglio Nazionale delle } \\
\text { Ricerche }\end{array}$ \\
\hline Japan & IV & Science Council of Japan \\
\hline Mexico & $\mathbf{I}$ & $\begin{array}{l}\text { Consejo Nacional de Ciencia y } \\
\text { Tecnologia }\end{array}$ \\
\hline Netherlands & II & $\begin{array}{l}\text { Stichting voor Fundamenteel } \\
\text { Onderzoek der Materie met } \\
\text { Röntgen- en Elektronenstralen }\end{array}$ \\
\hline
\end{tabular}

Secretary of National Committee

M. A. R. DE Benyacar, Division Física del Solido, Comisión Nacional de Energía Atómica, Av. del Libertador 8250, 1429 Buenos Aires

The Executive Secretary, Australian Academy of Science, PO Box 783, Canberra City, ACT 2601

A. Preisinger, Institut für Mineralogie, Kristallographie und Strukturchemie der Technischen Universität Wien, Getriedemarkt 9, A-1060 Vienna

E. Legrand, Materials Sciences Department, Studiecentrum voor Kernenergie, B- 2400 Mol

S. Caticha Ellis, DESCM, Instituto de Física, Universidade Estadual de Campinas, Campinas, São Paulo 13100

J. T. SZYMAŃSKI, CANMET, Department of Energy, Mines and Resources, 555 Booth St, Ottawa, Ontario K1A 0G1

D. Boys, Departmento de Física, Universidad de Chile, Casilla 5487, Santiago

XU XIAO-JIE, Department of Chemistry, Peking University, Beijing 100871

V. Petřiček, Physical Institute, Czechoslovak Academy of Sciences, Na Slovance 2, 18040 Praha 8

B. Jensen, Chemical Institute BC, Danish School of Pharmacy, Universitetsparken 2, Copenhagen DK-2100

S. A. AbDEl-HAdY, Faculty of Engineering \& Technology, Cairo Higher Institute of Technology, Helwan, Cairo

A. Vahvaselkä, Department of Physics, University of Helsinki, Siltavuorenpenger $20 \mathrm{D}$, SF-00170 Helsinki 17

Y. Epelboin, Association Française de Cristallographie, Tour 26, 4 place Jussieu, 75230 Paris CEDEX 05

P. RudolPH, Humboldt-Universität-Berlin, Skt. Physik, Ber. Kristallographie, Invalidenstr. 110, 1040 Berlin

H. Burzlaff, Institut für Angewandte Physik, Lehrstuhl für Kristallographie, Universität, Bismarckstr. 10, D-8520 Erlangen

P. Gadó, Pagony u.4, Budapest H-1124

A. K. SINGH, Materials Science Division, National Aeronautical Laboratory, Kodihalli, Bangalore 560017

M. HAREL, Weizmann Institute of Science, Rehovot

G. FilipPINI, Centro CNR, Dip. Chim. Fis. Elettrochim., Università di Milano, Via Golgi 19, 20133 Milano

J. HARADA, Department of Applied Physics, Faculty of Engineering, Nagoya University, Furoucho, Chikusa-ku, Nagoya 464

M. SorIANo-GarcIa, Instituto de Quimica, Circuito Exterior, UNAM, Delegacion Coyoacan, 04510 Mexico D.F.

The Executive Secretary, FOMRE, Koningin Sophiestraat 124, 2595 TM's-Gravenhage

* Adherence to the Union is in one of five Categories I-V, with corresponding voting powers and contributions as set out in Statutes 3.6, 5.5 and 9.4 . 
Country Category* Adhering Body

$\begin{array}{lll}\text { New Zealand } & \text { I } & \begin{array}{c}\text { The Royal Society of New } \\ \text { Zealand } \\ \text { Det Norske Videnskaps-Akademi }\end{array} \\ \text { Norway } & \text { I } & \text { Poland } \\ \text { I } & \text { Polska Akademia Nauk }\end{array}$

\begin{tabular}{|c|c|c|}
\hline Portugal & I & Sociedade Portuguesa de Física \\
\hline South Africa & I & $\begin{array}{l}\text { South Africa Council for } \\
\text { Scientific and Industrial } \\
\text { Research }\end{array}$ \\
\hline Spain & III & $\begin{array}{l}\text { Consejo Superior de } \\
\text { Investigaciones Cientificas }\end{array}$ \\
\hline Sweden & II & Kungliga Vetenskapsakademien \\
\hline Switzerland & II & $\begin{array}{l}\text { Schweizerische Gesellschaft für } \\
\text { Kristallographie }\end{array}$ \\
\hline UK & V & The Royal Society \\
\hline USA & V & $\begin{array}{c}\text { National Academy of Sciences- } \\
\text { National Research Council }\end{array}$ \\
\hline USSR & $\mathrm{v}$ & Akademija Nauk SSSR \\
\hline Yugoslavia & I & $\begin{array}{l}\text { Jugoslavenska Akademija } \\
\text { Znanosti i Umjetnosti }\end{array}$ \\
\hline
\end{tabular}

Secretary of National Committee

J. SiMPSON, Chemistry Department, University of Otago, PO Box 56, Dunedin

B. F. Pedersen, Institute of Pharmacy, University of Oslo, PO Box 1068, Blindern, 0316 Oslo 3

A. Pietraszko, Institute of Low Temperature and Structure Research, Polish Academy of Sciences, PO Box 937, 50-950 Wroctaw 2

M. M. R. R. CostA, Departmento de Física, Universidade de Coimbra, 3000 Coimbra

E. P. DU PLessis, South African ICSU Secretariat, CSIR, Foundation for Research Development, PO Box 395, 0001 Pretoria

M. MARTINEz Ripoll, Instituto 'Rocasolano', CSIC, Serrano 119, 28006 Madrid

P. KierkegaARD, Arrhenius Laboratory, University of Stockholm, S-106 91 Stockholm

H.-B. BÜRGI, Universität Bern, Laboratorium für Chemische und Mineralogische Kristallographie, Freiestrasse 3, CH-3012 Bern

The Executive Secretary, The Royal Society, 6 Carlton House Terrace, London SW1Y SAG

C. T. PrewitT, National Research Council, Commission on Physical Sciences, Mathematics and Resources, 2101 Constitution Avenue, Washington, DC 20418

V. I. Simonov, Institute of Crystallography, Academy of Sciences of the USSR, Leninsky prospekt 59, Moscow 117333

B. KAMENAR, Laboratory of General and Inorganic Chemistry, Faculty of Science, The University, Ulica Soc. Revolucije 8, 41000 Zagreb

* See footnote on preceding page.

\section{National Committees for Crystallography}

\section{Argentina}

S. BAGGIo (Chairman), M. E. J. DE ABELEDO, L. N. BECKA, D. Bedlivy, M. A. R. DE Benyacar, A. Bonfiglioli, M. BUTSCHOWSKI, E. E. GALLONI, M. IPOHORSKI, A. PODJARNY.

\section{Australia}

H. C. Freeman (Chairman), B. M. Gatehouse, I. E. Grey, S. R. Hall, E. N. Maslen, F. H. Moore.

\section{Austria}

A. Preisinger (Chairman), H. Heritsch, O. Kratky, H. NowOTNY, E. H. K. SCHMID, J. ZEMANN.

\section{Belgium}

G. KING (Chairman), J. MOREAU (Vice-Chairman), S. Amelinckx, L. Danguy, O. Dideberg, L. Dupont, F. Durant, G. Evrard, L. Fiermans, H. Geise, E. Legrand, P. Piret, H. Reynaers, J. VAN Landuyt, M. Van MEERSSCHE, J. VENNIK.

\section{Brazil}

R. Rodrigues da Silva (Chairman), S. Caticha Ellis, J. M. Correia Neves, C. Cusatis, Y. P. Mascarenhas.

\section{Canada}

G. Ferguson (Chairman), A. Beauchamp, G. W. BushNEll, R. B. Ferguson, O. KNop, B. M. Powell, J. T. SZYMANSKI, J. TROTTER.

\section{Chile}

O. Wittke (Chairman), E. Besoaín, D. Boys, H. Cid, J. A. Costamagna, C. Escobar, J. Garín, C. Infante, W. SCHLEIN, M. SUWALSKy, R. Vera, J. Ward.

\section{China, People's Republic of}

TANG You-QI (Chairman), LIANG DONG-CAI, MIAO FANGMING, FAN HAI-FU, FU HENG, LU JiA-XI, HUANG JIN-LING, Liang Jing-Kui, Shao MeI-Cheng, Yu Rui-huang, XU XIAO-JIE.

\section{Czechoslovakia}

J. GARA (Chairman), K. HuML (Vice-Chairman), J. ČER-

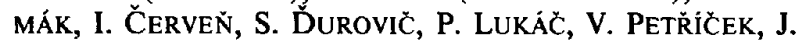
PODBRDSKÝ.

\section{Denmark}

B. Lebech (Chairman), F. Broesby-Olsen, B. Buras, J. Danielsen, R. Hazell, B. Jensen, B. Jerslev Lund, A. LINDEGAARD-ANDERSEN, E. MAKOVICKY, R. NORRESTAM, O. SIMONSEN. 
Egypt, Arab Republic of

M. S. Ahmed (Chairman), Y. M. AbBas, S. A. AbdelHady, A. M. Abdel-Reheim, E. A. Abou-SaIf, S. A. A. Arafa, M. A. E. Eid, I. S. Ahmed Farag, F. M. Helmi, M. E. E. Helmy, S. A. SAleh, F. H. Yousef.

\section{Finland}

P. SUORTTI (Chairman), K. V. J. KURKI-SUONIO, V. lindroos, A. Pajunen, J. Valkonen, A. Vorma.

\section{France}

J. F. Petroff (Chairman), R. Comes, Y. Epelboin, M. HoSPITAL.

\section{German Democratic Republic}

H. NeEls (Chairman), E. HöhNe (Vice-Chairman), J. Barthel, O. Brümmer, J. Heydenreich, G. Kötitz, P. PAufler, P. RudolPh, M. SCHENK.

\section{Germany, Federal Republic of}

W. Prandl (Chairman), W. Bronger, H. BurzlafF, H. Fuess, F. Liebau, W. Saenger, H. Stiller.

\section{Hungary}

L. Zsoldos (Chairman), I. DódONY, M. FARKAS-JAHNKE, P. Gadó, I. Hargittai, A. Kálmán, L. Malicskó, K. SASVÁri, K. Simon, E. SVÁb, I. Viczián.

\section{India}

M. A. Viswamitra (Chairman), R. Chidambaram, G. R. Desiraju, S. P. Sen Gupta, S. K. Sikka, A. K. Singh, O. N. Srivastava, E. Subramanian, M. Vijayan.

\section{Israel}

I. Goldberg (Chairman), J. Bernstein, A. Bino, M. HAREL, M. KafTORY, M. KAPON, G. KIMMEL, D. RABINOVICH.

Italy

G. Allegra (Chairman), M. Brunori, E. Cannillo, A. Coda, A. Della Giusta, G. Filippini, M. Fontana, C. Giacovazzo, C. M. Gramaccioli, U. Valdré.

\section{Japan}

S. Hoshino (Chairman), T. AshidA, J.-I. ChIKAWA, J. HaRada, Y. IITAKa, S. INo, H. IWASAKI, Y. Katube, S. KikUta, Y. Komura, F. Marumo, T. NishinaGa, I. Sunagawa, M. Tanaka, M. Tokonami, T. UeKI, K. Yagi.

\section{Mexico}

L. E. RENdón Díazmirón (Chairman), M. José YaCAMÁN (Vice-Chairman), O. Cano Corona, J. Capallera Cabada, M. Soriano García, J. Tacher y Samarel, $M$. DE TERESA Y CARRAL.

\section{Netherlands}

H. SChENK (Chairman), P. T. Beurskens, A. BRAAM, J. Drenth, D. Feil, R. A. G. DE GraAf, P. HARTMAN, R. B. Helmholdt, F. Th. Hesselink, J. Hornstra, A. M. Kroon, B. O. LoOpstra, A. LoOYenga-Vos, E. J. Mittemeijer, M. G. Northolt, A. F. Peerdeman, F. TUINSTRA, J. W. VISSER.

\section{New Zealand}

G. J. Gainsford (Chairman), B. K. Nicholson, C. E. F. Rickard, W. T. Robinson, J. Simpson, J. M. WATERS.

\section{Norway}

Chr. Rømming (Chairman), O. Foss, J. GıøNnes, F. Grønvold, A. Hordvik, F. Mo, B. F. Pedersen, T. G. STRAND.

\section{Poland}

K. Lukaszewicz (Chairman), J. Aulaytner (ViceChairman), Z. BoJARSKI, Z. GAEDECKI, Z. Kosturkiewicz, J. Leciejewicz, A. Pietraszko, J. Żmija.

\section{Portugal}

L. M. Alte da Veiga (Chairman), M. M. R. R. Costa, M. O. V. DE Figueiredo, J. LimA-DE-FARIA, R. A. QuadRAdo.

\section{South Africa}

G. HEYMANN (Chairman), J. C. A. BoEyens, G. J. KRuger, L. R. Nassimbeni, E. P. DU Plessis.

\section{Spain}

C. Miravitlles Torras (Chairman), M. I. Arriortua marcaida, A. Conde Amiano, F. Hernandez Cano, M. Martinez Ripoll, F. Sanz Ruiz, X. Solans Huguet.

\section{Sweden}

S. Abrahmsson (Chairman), I. Olovsson (ViceChairman), B. Aurivillius, O. Beckman, D. Carlström, N. INGRI, G. JOHANSSON, P. KIERKEGAARD, B. LINDQVIST, I. LindQvist, A. Magnéli, B. Strandberg, F. E. WICKMAN.

\section{Switzerland}

D. SChWARzenbach (Chairman), H.-B. BürGI, J. DALY.

\section{$U K$}

M. M. Woolfson (Chairman), D. M. Blow, D. W. J. Cruickshank, R. Diamond, D. Dineen, R. J. Elliott, P. F. Fewster, A. M. Glazer, R. Hine, M. H. Loretto, A. C. SkaPski, R. W. H. SMall, M. J. Whelan, J. ZusSman.

\section{USA}

L. Jensen (Chairman), D. SAyre (Vice-Chairman), D. AtKinson, B. BATterman, H. Berman, A. BIENENSTOCK, C. Brock, R. Bryan, C. BugG, J. CoWley, R. Dickerson, W. Duax, C. Foris, W. Hendrickson, Q. JohnSon, J. Karle, T. Koetzle, R. Newnham, H. Steinfink.

\section{USSR}

G. B. Bokiy, Z. G. Pinsker, I. I. Shafranovsky, N. N. SHEFTAL, V. I. Simonov, M. M. UMANSKY, B. K. VAINSHTEIN, G. S. ZHDANOV.

\section{Yugoslavia}

D. Grdenić (Chairman), A. BezJaK, L. Golič, R. HERAK, B. Kamenar, K. Kranje, I. Krstanović, S. Popović, V. Prodan, B. RIBÁR, S. ŠĆAVNIČAR. 